\title{
HYDROGEOCHEMICAL AND STREAM SEDIMENT RECONNAISSANCE BASIC DATA REPORT FOR KINGMAN NTMS QUADRANGLE, ARIZONA,CALIFORNIA, AND NEVADA
}

\author{
B. J. Qualheim
}

July 1978

Work performed under the auspices of the U.S. Department of

Energy by the UCLLL under contract number W-7405-ENG-48.

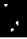

$\therefore$

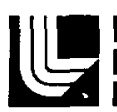

LAWRENCE

LVERMORE

LABORATORY

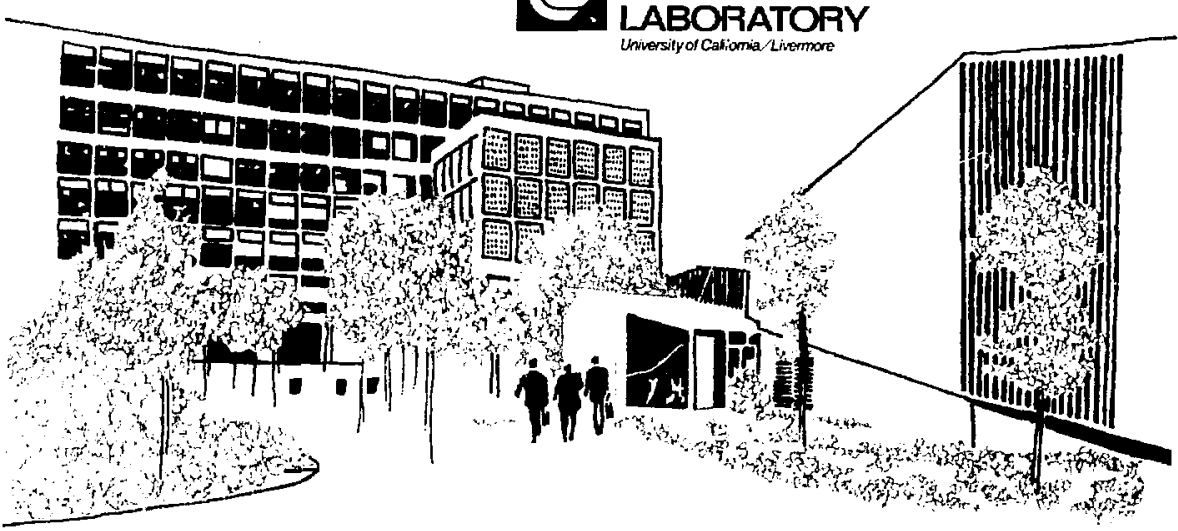


Decenber 21,1978

TO: $\quad$ A11 Holders of UCRL-52549 and UCRL-52550

FROM: Technical Information Department, L-255

\section{ERPATA}

Please make the following corrections to the Conductivity Maps in the back of the reports, UCRL-52549. "Hydrogeochemical and Stream Sediment Reconnaissance Basic Data Report for Kingman NTMS Quadrangle, Arizona, California, and Nevada" and UCRL-52550, "Hydrogeochemical and Stream Sediment Recunnaissance Basic Data Report for Las Vegas NTrS Quadrangle, Arizona, California, and Nevada".

In the center ard to the right of the Conductivity Maps of these two reporta, (Overlay 1C) it reads as follows:

CONDUCTIVITY ( $\mu$ NHO/SQ.CM)

Delete the $\mathrm{S} Q$. in some manner so it will read:

CONDUCTIVITY ( $\mu \mathrm{MHO} / \mathrm{CN})$

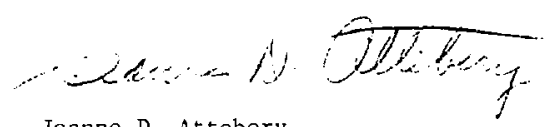

Jeanne D. Attebery

Technical Information Department 


\title{
L5
}

\section{I_AWRENCE I.IVERMORE I_ABORATORY}

University of Calfornia Livermore, Califoria 94550

UCRL.52549

\section{HYDROGEOCHEMICAL AND STREAM SEDIMENT RECONNAISSANCE BASIC DATA REPORT FOR KINGMAN NTMS QUADRANGLE, ARIZONA, CALIFORNIA, AND NEVADA}

\author{
B. J. Qualheim
}

MS. date: July 1978

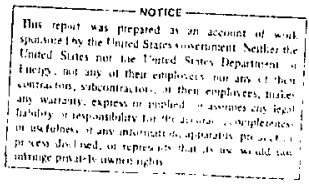




\section{CONTENTS}

Abstract . . . . . . . . . . . . . . . . . . . . . . . 1

Introduction ... . . . . . . . . . . . . . . . . . . . . . . 1

Location and General Topography . . . . . . . . . . . . . . . . 3

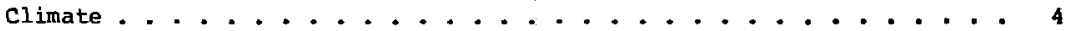

Hydrology ................................. 4 4

Geology of the kingman Quadrangla . . . . . . . . . . . . . . . 5

Reported Uranium Occurrences . . . . . . . . . . . . . . . . . . . . 14

Sample site selection and collection . . . . . . . . . . . . . . . 16

Quality Assurance . . . . . . . . . . . . . . . . . . . . 17

Relation of Analyses to Geology . . . . . . . . . . . . . . . . . . . . . 21

Acknowledgments . . . . . . . . . . . . . . . . . . . . . . . 24

References .................................. 25

Bibliography .. . . . . . . . . . . . . . . . . . . . . . . 27

Appendix A: Data Organization and Definitions . . . . . . . . . . A-1

Appendix B: Numerical Results of Reconnaissance Survey . . . . . . . . B-1

\section{FIGURES}

Figure 1. Areas of responsibility for the NURE Hydrogeochemical

Reconnalssance Program .................. . 2

Figure 2. Location of Kingman NTMS quadrangle . . . . . . . . . . . 3

Figure 3. Location of uranium occurrences - kingman WTMS sheet . . . 7

Figure A-1. Uranium concentrations in water samples . . . . . . . . . A-4

Figure A-2. Uranium concentrations in sediment samples . . . . . . . A-5

Figure A-3. Histogram (a) and cumulative frequency distribution

(b) of uranium concentration for water samples plotted

in overlay IB . . . . . . . . . . . . . . . . . . . . . . A-6

Figure A-4. Histogram (a) and cumulative frequency distr.bution

(b) of field conductivities for water samples

plotted in overlay $\mathrm{lC}$. . . . . . . . . . . . A-7

Figure A-5. Histogram (a) and cumulative frequency distribution

(b) of uranium concentration for sediment samples

plotted on overlay 2B ................ A-B

Figure A-6. Histogram (a) and cumulative frequency distribution

(b) of thorium concentrations for sediment samples

plotted on overlay 2C . . . . . . . . . . . . . . A-9 


\section{TABLES}

Table 1. Reported uranium occurrences . . . . . . . . . . . 8

Table 2. Instrumental neutron activation analysis sediment quálity data summary .................. 18

Table 3. Optical emission spectrometry (ICP) water quality assurance data summary ... . . . . . . . . . . 20

Table 4. Delayed neutron assay for uranium analyses of DOE interlaboratory comparison samples ............. 21

Table B-1. Sediment analysis; dry and stream sites . . . . . . . . B-2

Table B-2. Water analysis; streams ... . . . . . . . . . . . . B-37

Table B-3. Water analysis; spring and well sites . . . . . . . . . . B-38

\section{MICROFICHE TABLES (rear pocket)}

\section{OVERLA YS (rear pocket)}

Overlay 1A. Site Locations, Water Samples

Overlay 1B. Total Uranium Concentrations, Water Samples

Overlay 1C. Field Conductivity, Water Samples

Overlay 2A. Site Locations, Sediment Samples

Overlay 2B. Total Uranium Concentrations, Sediment Samples

Overlay 2C. Total Thorium Concentrations, Sediment Samples 


\section{HYDROGEOCHMEICAE AND STREAM SEDIMENT RECONNAISSANCE BASIC DATA REPORT FOR KINGMÃN NTMS QUADRANGLE, ARIZONA, CALIFORNIA, AND NEVADA}

ABSTRACT

This report presents the results of the geochemical reconnaissance sampling in the Kingman $1 \times 2$ quadrangle of the National ropographical Map Series (NTMS). Wet and dry sediment samples were collected throughout the 18,770-km arid to semiarid area and water samples at available streams, springs, and wells. Neutron activation analysis of uranium and trace elements and other measurements made in the field and laboratory are presented in tabular hardcopy and microfiche format. The report includes five full-size overlays for use with the Kingman NTMS 1:250,000 quadrangle. Water sampling sites, water sample uranium concentrations, water-sample conductivity, sediment sampling sites, and sediment-sample total uranium and thorium concentrations are shown on the separate overlays. General geological and structural descriptions of the area are included and known uranium occurrences on this quadrangle are delineated.

Results of the reconnaissance are briefly discussed anis related to rock types in the final section of the report. The restit.s are suggestive of uranium mineralization in only tow areas: the Cerbat Mountains and near some of the western intrusives.

\section{INTRODUCTION}

The National Uranium Resource Evaluation (NURE) program was established to evaluate domestic uranium resources in the continental U.S. and ijentify areas favorable for uranium exploration. The Grand Junction office (GJo) of the Department of Energy (DOE) is responsible for administering and coordinating NURE program efforts. Lawrence Livermore Laboratory (LLL) is conducting a hydrogeochemical and stream-sediment reconnaissance (HSSR) of 1.B million $\mathrm{km}^{2}$ in 10 western states, Other DOE laboratories are responsible for similar reconnaissance in the rest of the continental U.S. including Alaska (Fig. 1).

Before atarting a major field reconnaissance coverage, LLL conducts one or more orientation studies in the geological province, providing a rational 


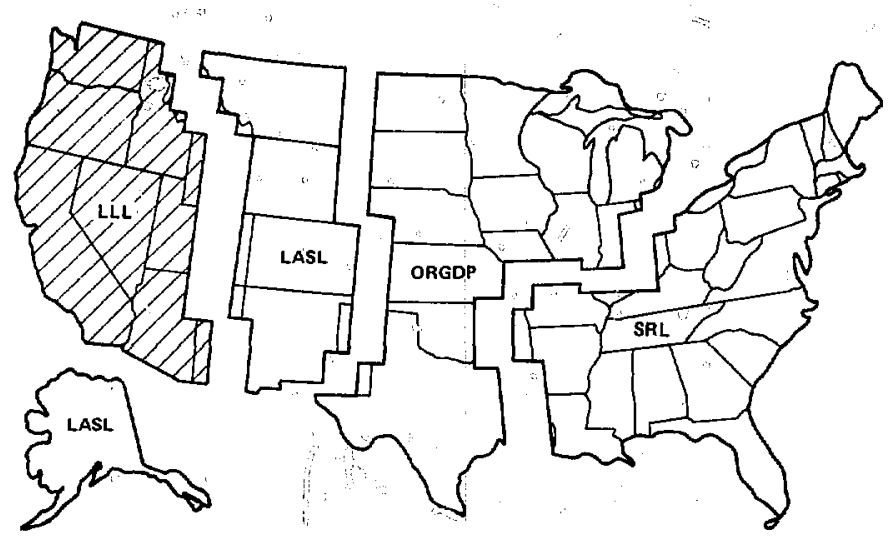

Fig. 1 Areas of responsibility for the NuRE Hydrogeochemical Reconnaissance Program.

sediment and water sampling program sensitive to variable geological and climatic conditions that exist in the area. ${ }^{1,2}$ In this way the sediment and water samples reflect, as nearly as possible, the metallogenic nature of the region with particular emphasis on uranium mineralization. A description of sample collection and processing methods is available.

The samples were anajyzed for uranium by delayed neutron sounting, and in some cases, by instrunental neutron activation analysis (INAA). Instrumental neutron activation analysis was used to measure trace and major element content of sediment samples. The neutron activation analysis and delayed neutron counting are performed using an automated transport and detection system described by smitis. ${ }^{3}$ Data reduction for neutron activation analytical resultg utilizes the GAMANAL code described by Gunnink and Niday ${ }^{4}$ to interpret the gamma spectra. The NURAB code described by Heft and Martin 5 and McMillan and Carver ${ }^{6}$ produces the elemental concentration values.

An automated optical emission spectrometer equipped with an argon plasma source provided trace and major element analyses of water samples. A modified spectrophotometric analyzer was used to obtain measurement of chloride and sulphate concentrations of water samples. 


\section{LOCATION AND GENERAL TOPOGRAPHY}

The Kingman National Topographic Map Series (NTMS 1:250,000) Quadrangle, located at the southern tip of Nevada (Fig. 2), covers an area of approximately $18,770 \mathrm{~km}^{2}\left(7,250 \mathrm{mi}^{2}\right)$.

The topographic features of the northwestern guarter of the area are characteristic of the Basin and Range Physiographic Province, with north-south trending mountain ranges separated by enclosed intermontana basins. The southwestern quarter, however, his several isolated irregular mountains and

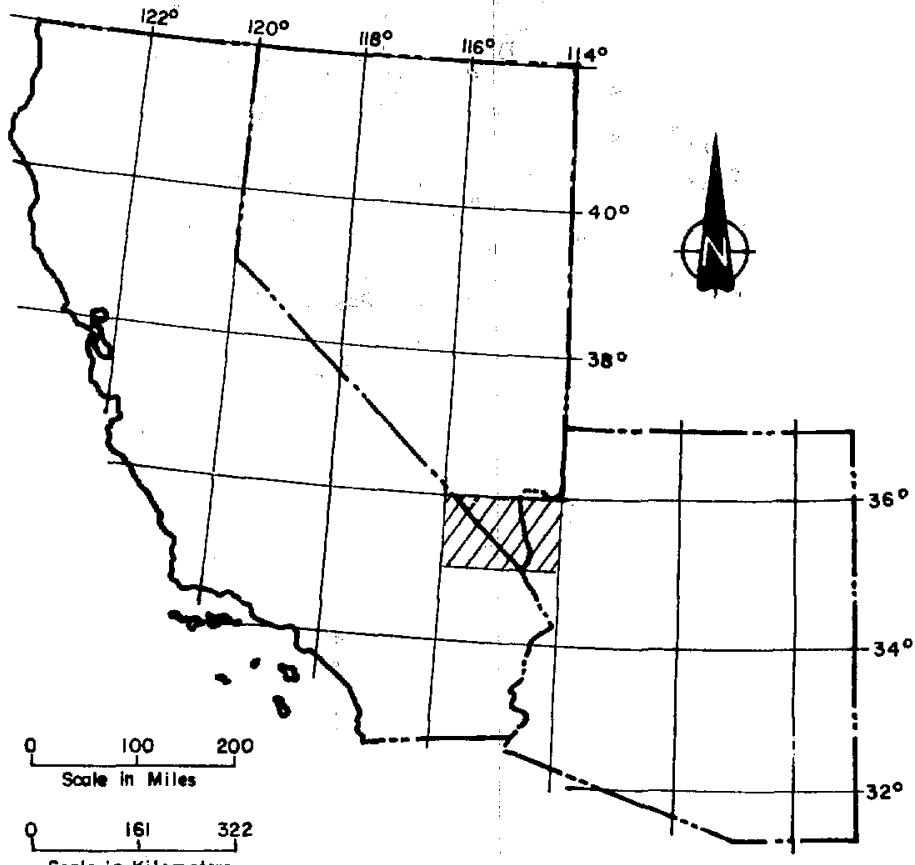

Scale in Kilometers

Fig. 2 Location map of Kingman NTMS quadrangle $(1: 250,000)$ 


\section{(1)}

ridges more characteristic of the Mojave Desert province. In the eastern half of the study area, the topographic features differ from the northwestern parts of the Basin and Range Province in that the mountain ranges have external drainage to the sea Via the Colorado River and its, tributaries. Ground-surface elevations range from approx/imately $2400 \mathrm{~m}(8000 \mathrm{ft})$ in the Spring Nountains to less than $200 \mathrm{~m}$ (700 ft) along the Colorado River.

\section{Climate}

The climate of the area is semiarid with an average rainfall of less than $25 \mathrm{~cm}$ (10 in.). The area west of the Colorado River was sampled during the months of February, March, and April, 1977 and the area east of the Colorado River was sampled in June and July 1977. During these months there was near-drought weather conditions. The average rainfall was 50-808 of normal, and consequently, many springs and streams that normally flow during this period were dry.

Temperatures in the sumer range from $40-43^{\circ} \mathrm{C}$ during the day and frequently as low as $-4^{\circ} \mathrm{C}$ at night. In the winter, freezing temperatures are uncommon below $600 \mathrm{~m}(2000 \mathrm{ft})$, with below freeaing temperatures occurring in the higher elevations. Strong winds are cormon, especially in the lower elevations with periods of extensive wind sediment transport. These wind conditions, along with the near-drought conditions could significantly increase the chances of windblown contamination in the lowlands.

\section{HYDROLOGY}

The major source of water in the study area is the colorado River and its tributaries. Most of the water from the colorado River is not available to Nevada for domestic purposes, although it is used for agriculture. Davis Dan has formed Lake Mohave, which is used for recreation and irrigation. Wells supply the majority of domestic water.

The springs in the study area are most conmon in the higher mountains, which are underlain by coarse granular and faulted, stratified rocks. These springs are found mainly in the western half of the quadrangle, such as the Kingston Range, Spring Mountains, Ivanpah Nountains, and the New York Mountains. Areas of metamorphic rocks, such as crystalline gneisses, act as poor aquifers and contain fewer springs. These areas that contain sparse 
springs include Mcrillough Range and several other smaller ranges. The springs at the base of the mountain ranges are commonly small seeps flowing only during the wet season; some at higher elevations flow all year. Most of the water is used for agriculture and livestock.

Wells in the area are found in the alluvial, valleys and are usually shallow, indicating shallow ground water tables. In places where there are deeper wells, however, aquifers contain water under sufficient pressure to cause it to $r$ ise near the surface. The aquifers are recharged by precipitation in the higher elevations.. Additional information on ground water in the area can be found in the following publications: Hewett, 7 Hewe,t, ${ }^{8}$ winograd and Thordarson," and Naff, et al. 10

\section{GEOLOGY OF THE KINGMAN QUADRANGLE}

\section{Structural History}

The geologic features of the area indicate periods of extensive deformation during at least four periods of geologic history. Disturbances occurred after deposition of the lower Precambrian rocks, in the later Precambrian, during the Cretaceous Laranide orogeny, and in the Late Tertiary. The disturbances were followed by intrusion of igneous rocks, extrusion of volcanics, and extensive erosion of pre-existing rocks. The major orogenic activity occurred düring the Laramide Orogeny, which began in the cretaceous and continued into the Tertiary. The sequence of structural activity during this period is summarized by Longwell, et al ${ }^{1.1}$ :

(1) Initiation of folds and large-scale thrust faults, accompanied by normal, steep reverse, and strike-slip faulting. Local accumulation of coarse clastic sediments derived from thrust plates and folds.

(2) Intrusion of plutonic rocks; initiation of volcanic activity.

(3) Dolomitization and other alterations of limestones.

(4) Large-scale normal faulting and volcanic activity.

(5) Repeated sedimentation within structural basins.

\section{Stratigraphy}

The Precambrian rocks of the Kingman quadrangle consist of three ige groups: the oldest group is made up of sedimentary and metasedimentary rocks 
and consists of a wide range of alterations, mainly to schists and marbles; the next younger group" consists of intrusive coarse-grained granites and syenites; and the youngest group consists of intrusive rocks varying in texture from aplite to pegmatites. These rocks crop ont in scattered localities throughout the study area; the largest areas are in the Mccullough Range, Opal Mountains, "Clark Mountains, Newberry Range, and the Cerbat Mountains east of the Colorado River. The clark Mountains contain the rare-earth-rich Mountain pass carbonatite sequence that is othought to be Precambrian in age. Anomalous thorium mi neralization is reported in the Mountaj.n Pass region. 12 uranium mineralization is found associated with precambrian quartz monzonites and along contact zones with older sedimentary; rocks.

In the Cerbat Mountains of Arizona, the Precambrian complex consists of gneisses and schists intruded by younger granite porphyries and lamprophyric dikes. Uraniuk mineralization has been reported along veins associated with intrusion of these dikes.

The Paleozoic rocks crop out mainly in the western half of the study area. These rocks consist of 70 to $80 \mathrm{z}$ limestone and dolomite with minor amounts of sandstone and shale. The formations that are represented, listed from oldest to youngest, include: the Cambrian to Devonian Goodspring Dolomite, the Silurian Sultan Limestone; the Mississippian Monte Cristo Limestone, and the Mississippian to Permian Bird Spring Formation. These formations crop out in the Goodsprings mining district (Fig. 3) and reportedly contain secondary uranium deposits associated with base metai mineralization. The Mesozoic rocks in the study area are largely marine sandstones and shales similar to some of the Colorado plateau rocks that crop out to the northeast. These rocks are exposed in the western half of the study area along the southern extent of the Spring Mountains. In the late Cretaceous to Tertiary, the Laramide orogeny produced widespread folding and faulting of the pre-existing rocks followed by intrusions of large bodies of granitic rocks. These granitic intrusions and the widespread faulting may be responsible for many of the uraniferous and me'illiferous deposits in the Goodsprings district.

Tertiary and Quaternary sedimentary rocks make up approximately 408 of the study area and consist of fluvial and lacustrine sediments. Secondary uranium mineralization has been reported in caliche and calcrete cemented Quaternary gravels (Table 1). 


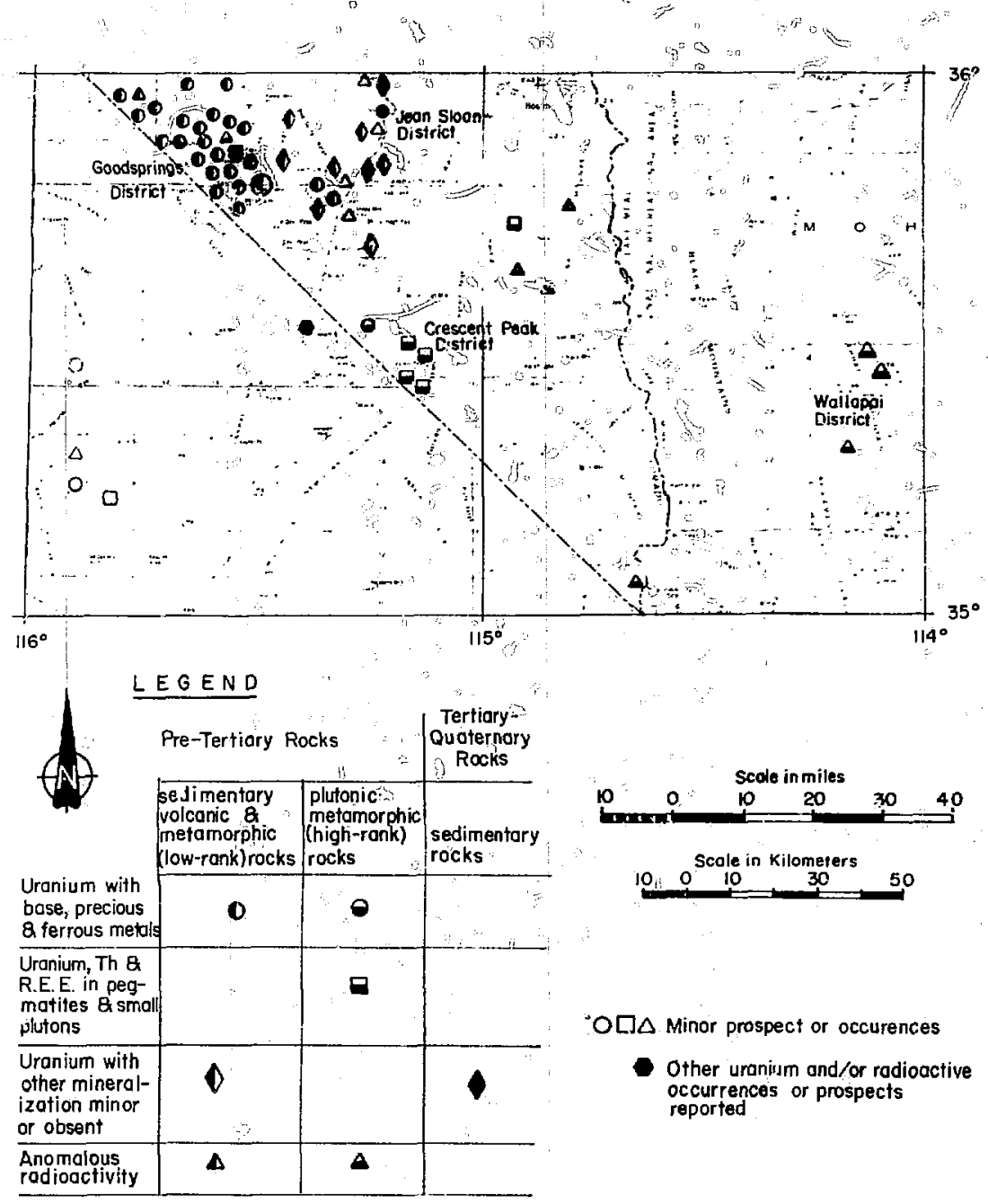

Fig. 3 Location of uranium occurrences - Kingman NTMS sheet 


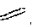

Table 1. Reported uranium occurrences In the Kingman Quadrangle 17,18

District or clatm

Superfluous No. 1

Unnamed

Jim Kane

RaInbow Group

Lucky Group

Prospector $1-20$

Location 6,7

Location 16

Surprise, Thor

H\&E
Paymaster

$\hat{y}$

Ünnamed

Unnamed

ítppeno

Lucy Gray

$\because$ Lucy

\section{Location}

it
Type of deposit

\section{0}

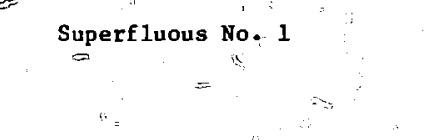

S.3
$\mathrm{T} .32 \mathrm{~S}, \mathrm{R} \cdot 64 \mathrm{E}$.

. 3.24

T.13N., R.10E.

s.8

T.13N., R.10W.

s. 8

T.24N., R.IZW.

B. 32

T.14N., R. 10E.

s:17

T.15N., R. 10E.

s. 21

T. 24N., R.17W.

$8 \cdot 17$

T. 24N., R.17W.

8. 3

T.29S •, R.61E.

$3.21,22,27$

T.28S., R.61E.

B. 17

T.28S., R.61E.

8.29

T.28S., R.61E.

B. 32

T.27S., R.60E.

B. 4

T.27S., R.64E.
Anomalous radioactivity near

contact between Precambrian

metasedimentary rocks and a

granitic intrusive.

Precambrian metamorphic

Precambrian metamorphic

Anomalous radioactivity associated with dike-cutting granitic rocks.

Precambrian granites

Precambrian metamorphics

Precambrian metamorphics (i)

Precambrian metamorphtcs

Radloactivity assoclated with dikecutting granitic rocks; $0.0874 \% \mathrm{U}_{3} \mathrm{O}_{8}$.

Anomalous radloactivity assovlated wth Precambrian quartz monzonite.

Anomalous uranium and thortum In Precambrian mylonitic augen gnelss.

Anomalous radloactivity where a Tertlary or Cretaceous quartz monzonite Intrudes Precambrlan rocks.

Anomalous radioactivity assoclated wth an elliptical breccla pipe In Precambrian grantte gnelss. $0.03-0.257 \mathrm{U}_{3} \mathrm{O}_{\mathrm{B}}$

Anomalous radioactivity in Precambrián rocks. 
Table 1. (continued)

District or

cla1m

Mary Helen and

Rose Allce

Yellow Jacket 1-15

Tam O'Shanter

Ingomarod-M1Iford No. 2

Big Horn cla1m

M\&E Ṇo. 1 and 12

LIncoln, LIttle Betty

Over Prospect

Bullion mine

Eureka mine

Volcano

Location s. 27

T.25S., R.58E.

5.14

T.26S., R.63T.

$\mathrm{s.7}$

T.26S., R.60E.

5.9

T.265., R.58E.

s. 9

T.26S., R.58E.

s.36

$\mathrm{s} .35$

T.25S., R.63E.

s.13, 24

T.25S., R.58E.

S. I

T.25S., R. 58E.

$\mathrm{s.} 23$

T.25S., R.58E.

s. 4

T.25S,, R.58E,.
T.25S., R.64E.
Type of deposit
Anomalous radioactivity in band of greenstone gneiss in Precambrian rocks.

Sparsely:disseminated autunite in a shear-zone cutting Precambrian rocks; $0.07-0.125 \% \mathrm{U}_{3} 0_{8}$.

Anomalous radioactivity fn brecclated zone assoctaced with copper oxide and limonite near base of Mississipplan Blrd Spring Formation.

Anomalous radioactivity associated with hydrozincite and limonite found along fractures in dolomitized portions of the Mississippian Yellowpine Limestone.

Anomalous radioactivity assoclated with fractures in Precambrian metasedimentary rocks; $0.07-$ $0.024 \% \mathrm{v}_{3} \mathrm{O}_{R}$ reported.

Anomalous radioactivity fn Precambrian gneiss and schist.

Slightly anomalous radloactivity associated with limontce and copper oxtde below top of Goodsprings Dolomite.

Anomalous zadloactivity assoclated with copper minerals.

Anomalous radioactivity assoclated with hydrozincite in a tabular breccla zone of the Anchor Limestone.

Slightly anomalous radioactivity associated with limonite and copper oxides in a dolimitized breccia of the Yellowpine Limestone.

Anomalous radioactivity associated with hydrozincite. 
Table 1. (continued)

$\begin{array}{lll}\text { District or } & \text { Location } & \text { Type of deposit } \\ \text { claim } & & \end{array}$

Hoosier

B1lly Wilson No. 1 , Sultan

Singer, Tiffin

Spelter

Jean Sloan

Jean Sloan

Jean Sloan No. 14

\section{Little Snake}

Purple Valentine

Jean Sloan No. 15

Jean Sloan No. 20

Wtllabelle Nunn, Jean Sloan No. 15

Sieber
5.20

T.25S., R.58E.

s. 20

T.25S., R.58E.

s. 18

T.25S., R. 58E.

S. 11

T.25S., R.57E.

s. 6

T.25S., R.60E.

s. 36

T.255., R.60E.

8.11

T.24S., R.60E.

8. 16

T.24S., R.60E.

B. 8

T.24S., R.60E.

8.29

T.24S., R. 60E.

B. 24

T.4S., R.59E.
Slightly anomalous radioactivity associated with hydorzincite and cerussite, in a crushed zone of dolomite near base of Bird Spring Formation.

Slightly anomalous radioactivity associated with 11 monite and hydrozincite in a brecciated dolomite along the sultan thrust fault.

Radioactivity in drifts and shafts assoclated with base metals.

Radioactivity assoclated with hydrozincite.

Carnotite occurs with caliche as coatings along foints in the Erie Tuff.

Small amounts of carnotite in Bird Spring Formation.

Small amount of tyuyamunite occurs as patches 10 callche cemented Quaternary gravel. Urantum content reaches $0.03 \% \mathrm{v}_{3} \mathrm{O}_{8}$.

Very small amounts of carnotite in gravels.

Traces of carnotite occurring along joints and slickensided minor faults in the Supal Formation.

Carnotite and $\mathrm{MnO}_{2}$ occur along bedding planes in the Permian Supal Formation.

Small amount of carnotite occurs with $\mathrm{MnO}_{2}$, gypoum, and calcite as specks and thin films along fractures In the Permian Supal Formation. 
Table 1. (continued)

District or

Location

Type of deposit

claim

Humd Inger

Jean Sloan 22-26

Jean Sloan No. 27

Hermosa, Surprise

Iron Gold Mine

Copper GIance mine

Allce, Yellow Pine

Alfce Fraction

Royal Blue

Fitzhugh Lee

Keystone mine

Unnamed

Highline, Oru Amigo s. 25

T.24S., R.59E.

$5 \cdot 14$

T.24S., R.58E.

s. 32

T.24S., R.58E.

8.21

T.24S., R.58E.

s. 20

T.24S., R.58E.

5.20

T.24S., R. $58 \mathrm{E}$.

$\mathrm{s} .32$

T.24S., R.58E.

9.36

T.24S., R.58E.

s. 30

T.24S., R.58E.

s.1, 12

T.245., R.57E.

S.23, 26

T.24S., R.57E.
Small amount of carnotite occurs in sandstone and Ifmestone of the Permian Toroweap Formation

Small amount carnotite in fractures in sandstone of Toroweap Formation.

Slightly anomalous radioactivity occurs associated with limonite, cerussite, wulfentte, and galena in a breccla zone along bedding planes of the Bird Spring Formation.

Water from 100-ft mine shaft shows anomalous uranium occurring in shales, limestones, and tuffs of the Trlassic Moenkop1 Formation that is cut by a grantte porphyry dike.

Anomalous radioactivity along vertical shear zone in dolomite assoclated with copper oxides.

Slightly anomalous radioactivity associated with limonite in the Bird Spring Formation.

Anomalous radioactivity associated with Iimonite and copper oxides.

Slightly anomalous radloactivity associated with limonfte, malachite, chrysocolla in shear zone of the Monte Cristo Limestone.

Slightly radloactive 11monite

Slight radfoactivity associated with limonite lenses along a minor fault zone in the Monte Cristo Limestone.

Anomalous radioactivity associated with limonite and copper minerals In shear rone in Sultan Limestone. 
Tsble 1. (continued)

\begin{tabular}{|c|c|c|}
\hline $\begin{array}{l}\text { District or } \\
\text { elaim }\end{array}$ & Location & Type of deposit \\
\hline $\begin{array}{l}\text { Rosetra } 1 \text { and } 2 \text {, Shenan- } \\
\text { doah, Ironside, Smith- } \\
\text { sonite, Copperside. }\end{array}$ & $\begin{array}{l}\text { s.25, } 26 \\
\text { T.24S., R.57E. }\end{array}$ & $\begin{array}{l}\text { Anomalous radioactivity associated } \\
\text { with limonite and copper oxfde } \\
\text { minerals in the Sultan Limestone. }\end{array}$ \\
\hline 50 s & $\begin{array}{l}s .34 \\
\text { T.24S., R.57E. }\end{array}$ & $\begin{array}{l}\text { Anomalous radioactivity in limonite } \\
\text { lenses along a minor fault zone } \\
\text { in the Monte Cristo Limestone. }\end{array}$ \\
\hline Mohawk No. 7 & $\begin{array}{l}\text { S.4 } \\
\text { T.24S., R.57E. }\end{array}$ & $\begin{array}{l}\text { Anomalous radioactivity associated } \\
\text { with shear zone in Bullion Limestone. }\end{array}$ \\
\hline Platina & $\begin{array}{l}3.34 \\
T .24 S ., R .57 E .\end{array}$ & $\begin{array}{l}\text { Radioactivity associated with } \\
\text { Ilmestone and chrysocolla in the } \\
\text { Monte Cristo Limestone. }\end{array}$ \\
\hline Jean Sloan 9 to 13 & $\begin{array}{l}\mathrm{S.2} \\
\mathrm{T} .24 \mathrm{~S}, \mathrm{R} \cdot 60 \mathrm{E}\end{array}$ & $\begin{array}{l}\text { Carnotite occurs as specks and } \\
\text { coatings on folnts in the Erie } \\
\text { Tuff; } 0.008 \% \mathrm{U}_{3} \mathrm{O}_{8} \text { reported. }\end{array}$ \\
\hline Jean Sloan 6,7 & $\begin{array}{l}\mathrm{s} .25 \\
\mathrm{~T} .23 \mathrm{~S} ., \mathrm{R} .60 \mathrm{E}\end{array}$ & $\begin{array}{l}\text { Carnotite found along Joints and } \\
\text { fractures in the Bird Spring Forma- } \\
\text { tion and Erie Tuff Formation, } \\
\text { selected samples as high as } 0.04- \\
0.70 \% \mathrm{U}_{3} \mathrm{O}_{8} \text {. }\end{array}$ \\
\hline Jean SIoan No. 4 & $\begin{array}{l}8.13 \\
\text { T.23S., R.60E. }\end{array}$ & $\begin{array}{l}\text { Carnotite sparsely disseminated in } \\
\text { caliche-cemented Quaternary gravel. }\end{array}$ \\
\hline Jean Sloan 2,3 & $\begin{array}{l}\text { S.1, } 12 \\
\text { T.235., R.60E. }\end{array}$ & $\begin{array}{l}\text { Small amount of carnotite found along } \\
\text { Joints fn the Bfrd Spring Formation. }\end{array}$ \\
\hline Jean Sloan No. 1 & $\begin{array}{l}\text { S.2 } \\
\text { T.23S., R. 60E. }\end{array}$ & Same as above. \\
\hline Sloan Carnotite & $\begin{array}{l}\text { Q.27 } \\
\mathrm{T} \cdot 24 \mathrm{~S} ., \mathrm{R} .60 \mathrm{E} .\end{array}$ & No information avallable. \\
\hline Paradise & $\begin{array}{l}\text { S.35 } \\
\text { T.23S., R.57E. }\end{array}$ & $\begin{array}{l}\text { Anomalous radioactivity associated } \\
\text { with hydrozincite in the Monte } \\
\text { Cristo Limestone. }\end{array}$ \\
\hline Coodspeings Carnotite & $\begin{array}{l}\mathrm{s.14} \\
\mathrm{T} .23 \mathrm{~S} ., \mathrm{R} .58 \mathrm{E} .\end{array}$ & No Information avallable. \\
\hline
\end{tabular}


Table 1. (continued)

$\begin{array}{ll}\begin{array}{l}\text { District or } \\ \text { claim }\end{array} & \text { Location } \\ \end{array}$

Danlel Boone

Green Monster

Desert Valley mine

Potos 1 s. 1

T.24S., R.56E.

The Green Monster Mine is the best uranium occurrence in the quadrangle. Urantum is assoclated with limonite, chrysocolla, and hydrozinclte. Ore is localized along brecclated fault intersections. Primary uranium could be present at depth. Selective urantum samples contain up to $10.5 \% \mathrm{U}_{3} \mathrm{O}_{\mathrm{B}}$.

Slightly anomalous radioactivity associaced with limontte, galena, and oxides of copper, $z$ inc, and lead minerals. Minerals occur along a shear zone in the dolomitized Bullion Limestone.

S.2
T.24S., R.56E.

Anomalous radioactivity associated with dark brown sphalerite and white calcite in a breccla of gray dolomite and carbonaceous shale. Reported uranfum contents reach $0.013 \% \mathrm{U}_{3} \mathrm{O}_{8}$.

The Cretaceous to later Tertiary plutonic rocks crop out along the Colorado River and in areas in the southern half of the study area. The composition of these intrusive bodies ranges from medium-grained to coarse-grained granite and quartz monzonite to diorite.

The volcanic rocks have a wide distribution in the area. In the Eldorado Mountains, several thousand meters of volcanic rocks overlie the Precambrian basement. These rocks consist of flow breccia of mafic to intermediate composition, minor ash flow tuff, bedded turf, and rhyolite. ${ }^{13}$ In the western half of the area, the volcanic rocks consist of andesite, rhyolite, minor pyroclastics, and Quaternary basalt. Anomalous uranium occurrences have been reported in the Jean-sloan area associated with the Erie Tuff. ${ }^{14}$

Detailed geologic map coverage of the Kingman NTKS Quadrangle is found in Refs. 11,15 and 16 . 


\section{REPORTED URANIUM OCCURRENCES}

The area contains numerous mineral deposits. These deposits fall into two groups: metallic deposits, which are numerous and widely distributed, and non-metallic, which are found only in selected areas. The first metallic deposits were discovered in the 1850 's and have produced significant quantities of gold, silver, copper, lead, zinc, iron, tungsten, and molybdenum. The nonmetallic deposits consist of limestone, dolomite, gravels, and gypsum.

Presently, there is no active uranium production in the quadrangle. There are, however, sixty-three reported uranium occurrences. 17.18 These occurrences are shown in Fig. 3 and summarized in Table 1. The major uranium occurrences are found in the Goodsprings, Jean-sloan, Crescent Peak, and Wallapi districts (Fig. 3). Other minor anomalous areas are found in the Eldorado Mountains and north of old Dad Mountain.

In the Goodsprings District, ore deposits have been developed primarily for gold, copper, cobalt, nickel, silver, lead, and zinc. The district contains the only property that has produced uranium. The Green Monster mine shipped five tons of $1.09 \% \mathrm{U}_{3} \mathrm{O}_{8}$ in 1951. The uranium is found associated with limonite, hydrozincite, ferruginous chert, carbonaceous shale, and secondary copper minerals. Barton and Behre ${ }^{14}$ found that 45 out of 85 of the mines examined in the Goodsprings area contained anomalous uranium mineralization. The following is a summary of their conclusions on the uranium in the Goodsprings District:

All cocurrences are very low grade, and, with the possible exception of the Green Monster mine, there is little possibility of production.

- Megascopic uranium minerals are rare; kasolite, dumontite and an unidentified green uranium mineral have been reported.

- Radicactivity is concentrated in the shallow oxidized zones of deposits associated with limonite, hydrozincite, chrysocolla, ferruginous chert and was concentrated by adsorption on colloids. The adsorption is reversible, and uranium can be released to solution.

- The best uranium occurrences are in lead-zinc mines near copper mineralization. There is no correlation of uranium occurrences with cobalt, vanadium, gold, silver, or molybdenum.

- The westernmost mines of the Goodsprings district tend to be more radioactive. 
- The source of the uranium was probably primary pitchblende, which is more closely associated with copper and iron minerals.

- Mineralization occurs along brecciated or fracture zones in Paleozoic carbonates.

The uranium mineralization in the Jean-Sloan area (Fig. 3) is found as carnotite-coated pebbles or disseminations and joint fillings in caliche or calcrete and in Quaternary gravel located down-dip from the late Tertiary Erie Tuff. Barton and Behre summarizes the uranium occurrences in the Jean-Sloan area:

- The uranium mineral is universally carnotite.

- All deposits are precipitated from ground water above the water table in recent geologic time; the mode of deposition is similar to caliche.

- structural control is effective in the localization of the mineral deposits; joints and minor faults provide channels for circulating ground vater.

- The known deposits are very low grade, and there is little possibility that they are related to large undiscovered deposits of the same type.

- The source rock of the uranium and vanadium is the Erie Tuff, which is anomalously high in uranium.

- The occurrence of manganese dioxide and uranium are independent in their occurrence.

- The Erie Tuff is an extruded part of a uranium-rich residual magmatic fluid.

- It is possible that the same magmatic process that produced the tuff could have formed large deposits at depth. The depth of these potential deposits could be excessive.

- The vent from which the tuff was erupted is probably located east or southeast of Erie and is probably covered by recent sediments or volcanics.

In the Crescent Peak area, uranium and thorium occur associated with uranium-bearing minerals in Precambrian pegmatites and other strall intrusive bodies. Rare earths are also present at some localities. The uranium and thorium occur as impurities and chemical substitutions in xenotime, zircon, monazite, and allanite. These rocks are unlikely to contain economic deposits but could be a source rock for younger undiscovered ore bodies.

The uranium mineralization in the Eldorado Mountains is reported 17,18 to be anomalous radioactivity along fracture systems in Precambrian metasedimentary rocks. 
The uranium mi meralization in the Cerbat Mountains (Wallapai district) of Arizona occurs associated with lead-zinc vein deposits. ${ }^{19}$ The veanium in the lead-zinc veins occurs as fine disseminations in inclipient fractures associated with sphalerite. Samples from this district average $0.058 \mathrm{v}_{3} \mathrm{O}_{\mathrm{B}}$.

Other smaller occurcences are reported by Larson et al. ${ }^{18}$ in the southwestern corner of the quadrangle near old Dad Mountain. The four ccurrences near Old Dad Mountain are minor oscurrences associated with metamorphic and granitic rocks.

\section{SAMPLE SITE SELECTION AND COLLECTION}

The selection of representative sample sites is the most important aspect of sample acquisition. The following criterion were considered in the site selection process:

- Sites were chosen to measure the mobility of uranium in various geological environments.

- Sites were selected to minimize environmental contamination from agriculture, mining, etc.

- Sites were selected along liange fronts to insure minimum windblown contamination.

- Samples along the fan aproris and in lowlands were biased toward ground water with minimal surface sampling because of windblown contamination.

- In smaller drainages, samples were taken along the range fronts at the apex of alluvial fans.

- In larger drainages, sites were placed up the canyons along tributaries to obtain representative coverage.

- To compensate for windblown contamination, sediments were sieved to eliminate finer. Sediments sampled and reported are the fraction between 500 and $1000 \mathrm{\mu m}$.

The average sediment-Bite density attempted for the quadrangle was one site per $13 \mathrm{~km}^{2}$, however, the actual site density averages one site per 15 $\mathrm{km}^{2}$ because of areas omitted for various reasons. Areas excluded from sampling or areas where the sampling density is lower include the playa lakes and large alluvial valleys.

To minimize the temporal factor, available water was sampled over a short period during the spring and sumer of 1977. Because the region was at near-drought conditions, the uraniun concentrations are probably at the 
maximum values. For this reason, sampling during a wetter year might result in uranium values lower than those collected in 1977.

site selection was performed by LLL geologists and sampling was done by contract geologists in areas west of the Colorado River. Site selection and sampling in areas east of the Colorado River were performed by Bendix Field Engineering Corporation geologists. Groundwater site selection and sampling was conducted by the University of Nevada - Desert Research Institute.

\section{QUALITY ASSURANCE}

\section{Field Sampling}

Lawrence Livermore Laboratory observers occasionally accompanied the contract sampling crews; LLU geologists resampled approximately 5i of the project sites. More than 95\% of the resampled sites were accurately located on available maps or photos. The remaining sites were plotted within $200 \mathrm{~m}$ of the correct location.

Samples from the site revisits are reported in the tables by quality control $x$-reference numbers and the aiternate site numbers are tabulated. Analytical replicates were also run on about $10 \%$ of all samples. Comparison of the sediment replicate results with the original samples shows a 10 \% standard deviation in measurement values. This 108 is the natural variability of the sampling and analysis.

\section{Laboratory Analysis}

Neutron activation analysis (INAA) and delayed neutron counting (DNC) are performed using ther automated transport and detection system installed at the Livermore Pool Type Reactor. Water samples are analyzed by optical emission apectronetry using an inductively coupled argon plasma (ICP) source.

The data reduction for neutron activation analytical results utilizes the GAMANAL code ${ }^{4}$ to interpret the gamma spectra and the NURDAC ${ }^{5,6}$ cole to produce elemental concentration values. Not all elements can be identified in every sample. Our experience suggests that, in general, the detection limits for elements reported here are those given in colunn 2 of Table 2 .

The error assoclated with a DWC uraniuri measurement is typically 18 of the reported value for sediments and 2 for water analyses. 
Table 2. Instrunental Neutron Activation Analysis Sediment Quality Assurance Data Summary

\begin{tabular}{|c|c|c|c|}
\hline Eleirent & $\begin{array}{l}\text { Detection } \\
\text { Iimit, (a) ppm }\end{array}$ & $\begin{array}{c}\text { Prectsion, (b) } \\
z\end{array}$ & $\begin{array}{r}\text { Accuracy } \\
7 \text { bias } \\
\end{array}$ \\
\hline $\mathbf{A g}$ & 500 & ND & ND \\
\hline $\bar{A} \mathbf{I}$ & 50. & 10 & -7 \\
\hline $\mathbf{A g}$ & 3. & 6 & -1 \\
\hline $\mathbf{B a}$ & 100 & 13 & ND \\
\hline $\mathrm{Br}$ & 5. & ND & NR \\
\hline $\mathrm{Ca}$ & 20,000 & 7 & ND \\
\hline $\mathrm{Ce}$ & 15. & ND & $\mathrm{NR}$ \\
\hline c1 & 50. & ND & NR \\
\hline Co & 3. & 5 & +6 \\
\hline $\mathrm{Cr}$ & 30. & 8 & +13 \\
\hline $\mathrm{Cs}$ & 30. & 5 & NR \\
\hline Dy & 0.2 & 10 & NR \\
\hline Eu & 0.1 & 16 & NR \\
\hline $\mathrm{Fe}$ & 2,000 & 5 & 5 \\
\hline Hf & 1. & 14 & NR \\
\hline $\mathrm{Hg}$ & 500. & ND & NR \\
\hline $\mathbf{K}$ & 2,000 & 7 & ND \\
\hline La & 0.3 & 4 & NR \\
\hline Lu & 2 & 22 & NR \\
\hline $\mathbf{M g}$ & 50. & 10 & +4 \\
\hline Mn & 0.2 & 4 & +11 \\
\hline $\mathrm{Na}$ & 20. & 4 & 0 \\
\hline $\mathbf{R} \mathbf{b}$ & 150. & 4 & ND \\
\hline Sb & 0.5 & 4 & -5 \\
\hline Sc & 0.1 & 5 & -1 \\
\hline Sm & 0.3 & 4 & NR \\
\hline Sr & 40. & ND & ND \\
\hline $\mathrm{Ta}$ & 3. & 20 & NR \\
\hline $\mathrm{Tb}$ & 20. & ND & NR \\
\hline $\mathrm{Th}$ & 2. & 4 & -6 \\
\hline $\mathrm{TI}$ & 200. & 8 & +2 \\
\hline $\mathbf{U}$ & 2. & 12 & -4 \\
\hline$V$ & 1. & 5 & +4 \\
\hline $\mathrm{W}$ & 30 . & ND & NR \\
\hline $\mathbf{Y b}$ & 3. & 13 & -6 \\
\hline $\mathbf{z n}$ & 200 & 16 & ND \\
\hline
\end{tabular}

ND = not detected

NR = not reported for standards.

(a) Approximate lower limite for detection in "typlcal" sediment samples.

(b) Precieion is an estimate of the reproduclbility of analyses. Values entered are percent standard deviation of a measurement for 30 analyses of control samples over a flve month period. (See footnote $c$, Table 4.)

(c) Accuracy is a measure of anilytical agreement with "known" values. Eatries are the percent deviation from unity of the ratio of measured to known values, averaged for 15 measurements obtalned over a fivemonth period. (See footnote $d$, Table 4.) Known values were obtained from the Canadian Aasociation for Applied Spectroscopy. 
The enission spectrometer data is automatically referenced to a known laboratory standard analyzed between each group of six samples. System calibration against a second, known standard solution precedes each batch of 72 samples. Water data from the Las Vegas quadrangle region were taken from "lab acidified" samples. Unacidified, filtered (0.45 $\mathrm{m})$ water samples were collected and returned to LLL, placed in storage for several months, acidified to approximately pH 1, and allowed to stand for two weeks prior to analysis. This procedure was applied after it was noted that in several of the plastic bag-lined-bottles, the plastic bags had broken. It is uncertain if lab acidification completely reversed precipitation of certain components or exchange reactions with the polyethylene container. Therefore, the user should be aware that some analyses may not be representative of the actual water composition.

six types of samples are routinely run for calibration of the various analytical systems and as a quality assurance measure.

- Elemental standards are used to establish emission spectrometry and spectrophotometry calibration and to determine physical paiameters used in the activation analysis system.

- Blanks are processed along with samples and analyzed to detect any source of contamination. Wo significant amount of an element reported here has been detected.

- Splits of samples are analyzed to determine whether the results of all analytical systems are reproducible. These data are included in the microfiche data tables. Reproducibility is generally found to be within the estimated standard deviations of the measurements.

- Quality control samples are run by all systems at an approximate ratio of 1:30 to check precision of the measurements and to detect long term drift. Results are summarized in Table 2, column 3. The accuracy of the measurements is generally comparable to the errors estimated from the analytical uncertainties.

- Standard reference materials are analyzed to determine the accuracy of the measurements in actual samples. Results are tabulated in Table 3 . In general, the bias is comparable to the precision of the measurement.

- Interlaboratory comparison samples for raraniun are distributed under the auspices of DOE to the various laboratories participating in the NURE program. Analyses of these samples are collected and reported monthly by the Ames Laboratory. ${ }^{20}$ Thls data is sumarized in Table 4. 
Table 3. Optical Enisston Spectrometry (ICP) Water Qualfty Assurance Data Summary

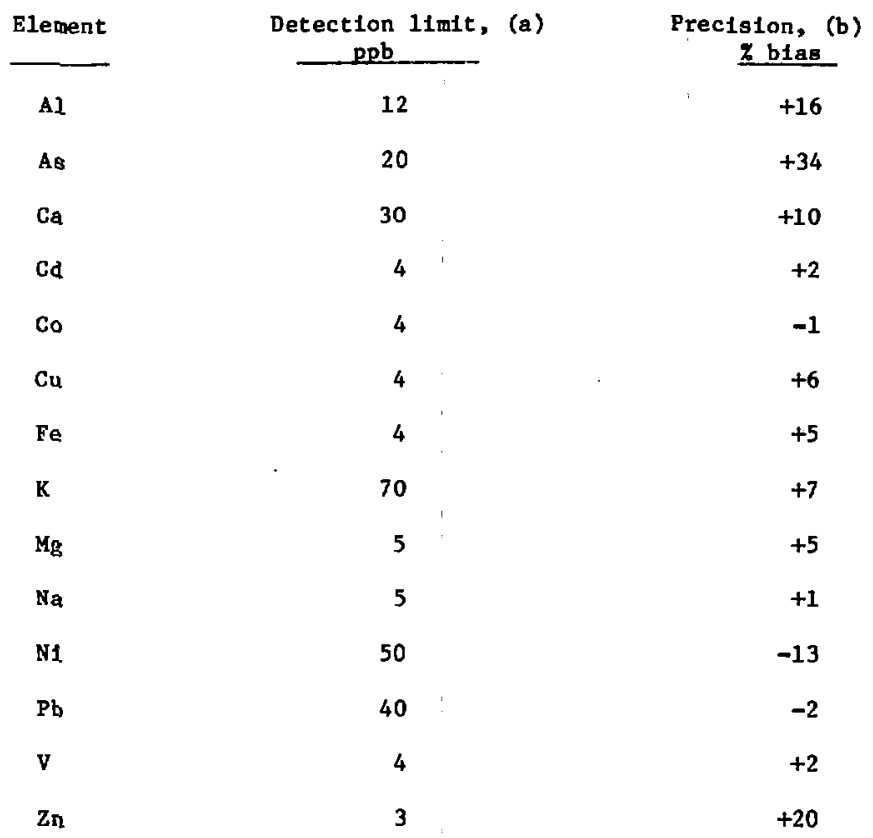

a) Approximate lower Ifmits of detection in water samples. Values given are four times the standard deviation of the background In each elemental channel.

b) Prectsion is a measure of analytical agreement with known values. Entrles are the percent deviation from unity of the ratio of measured to known values averaged for 15 measurements. (See footnote d, Table 4.) Known values were obtained from the Environmental Protection Agency.

While care has been taken to provide rellable sampling and analyses, verification of individual analyses is beyond the scope of this report. The data should be viewed statistically because "one-point anomalles" may be misleading. Regional trends, however, should be reliable. 
Tablè 4. Delayed Neutron Assay For Urantum Analyses of DOE Interlaboratory Comparison Samples

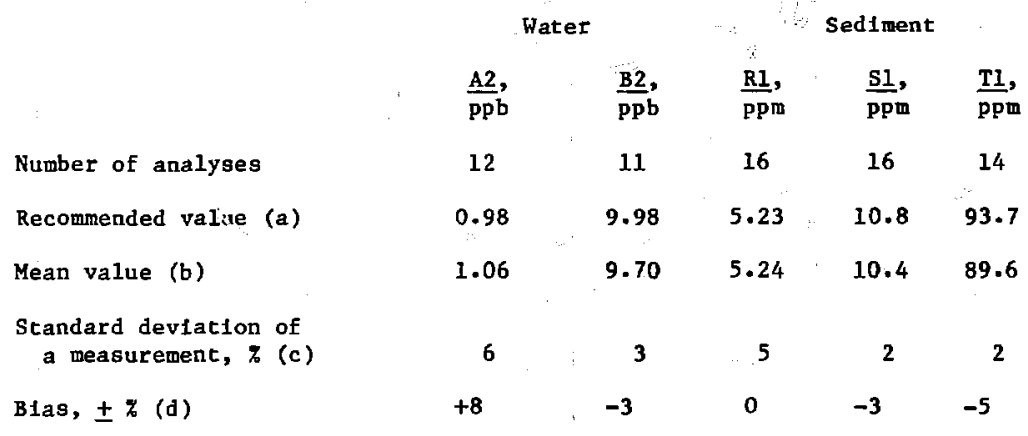

(a) Recommended values are averages of analyses by three Independent laboratorles.

(b) Mean of LLL measurements.

(c) $\frac{100}{\bar{x}}\left[\Sigma(x-\bar{x})^{2} /(n-1)\right]^{1 / 2}$

(d)

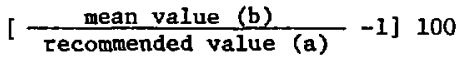

\section{RELATION OF ANALYSES TO GEOLOGY}

\section{Uanium and Thorium}

In order to provide the data as soon as possible, no detailed interpretation of geochemical relationships are provided in this report.

A logarithmic histogram and a cumulative-probability curve for uranium concentrations are provided for water and sediment samples. An additional logarithmic histogram and cumulative probability curve is provided for thorium concentration in sedinent samples. (They are Included in Appendix A.) 
Interpreting large data sets where individual samples must be compared with different thireshold values is a problem in a large-scale drainage survey over a range of rock types. Gouett et $a^{21}$ have show that logarithmic transformations of large geochemical survey data, such as the Kingman quadrangle, cause enhancement of the background populations and suppression of the anomalous population in the overall statistical distribution. Therefore, population recognition and sorting is vital to the statistical interpretation.

However if a region is subdivided into populations of similar rock types, statistical studies may be meaningful. In the Kingman quadrangle the major rock types separated are: carbonates of the Goodsprings district; Precambrian granites and granite gneiss of the Cerbat Mountains; ther cretaceous to Tertiary volcanics of the Black Mountains and generally north along the colorado river; the metasedimentary rocks of the McCullough and Newberry Wountains, and the intrusive formations generally in the western and southwestern area of the quadrangle. These are separated from each other by alluvial valleys. Each of these is briefly discussed below.

\section{Cerbat Mountains}

The highest uranium occurrence was found in the Cerbat Mountains. Uranium in the sediment samples varies from 0.5 to 47.5 ppm and has an average value of $4.2 \mathrm{ppm}$. The uranium correlates positively with thorium and the rare earths and negatively with sodium. However, in the richest uranium samples the Th to $U$ ratio is less than three. These values are associated with Precambrian granite and granite gneiss. The uranium in ground water samples varies from 2 to $216 \mathrm{ppb}$ and has an average value of about $30 \mathrm{ppb}$. The highest values are associated with the same type rocks as the highest sediment values but are more widely distributed.

\section{Cretaceous to Tertiary Volcanics of the Black Mountains and Areas Along the}

\section{Colorado River}

There were no high values of uranium found in the sediments associated with the volcanics in the area. The highest value observed was 5 ppm and the lowest 0.9 ppm. Concentration of uranium in ground water ranged from less than 2 ppb to $14 \mathrm{ppb}$.

\section{Quaternary Alluvium}

Nothing of significance was observed associated with these sediments. 


\section{Goodsprings District}

This is an area of known uranium occurrence; however, the results of the survey do not suggest extensive uranium mineralization. In the sediment samples the maximum concentration of uranium was $23 \mathrm{ppm}$, the lowest $0.8 \mathrm{ppm}$, and the average $1.8 \mathrm{ppm}$. The thorium-to-uranium ratio for the higher values of uranium was often less than two. The highest value of uranium in water was $32 \mathrm{ppb}$.

\section{Crescent Peak District}

This is also an area of known uranium occurrence. In sediments the concentrations of uranium vary from 0.5 to 13 ppm with most values less than 5 ppm. The uranium was strongly correlated with thorium and the rare earths. The two highest values were associated with Precambrian rocks in the southern portion of the McCullough Range. Uranium in the three samples of ground water ranged from 3 to $12 \mathrm{ppb}$.

\section{Western Intrusives}

Only minor uranium occurrence has previously been identified with these rocks. The sediment samples had uranium concentrations ranging from 0.8 to 40 ppm with an average value of $1.9 \mathrm{ppm}$. The high values were associated with contacts in the Kingston Range on both sides of a lower Precambrian outcrop. The analysis shows high iron, rare earths, scandium, and manganese and has low sodium. The water samples from these sites were also among the highest associated with the intrusives. Values of uranium concentrations in water from two sites in the Kingston Range were 12 and $27 \mathrm{ppb}$. Relatively high uranium in water sites were also found north of old Dad Mountain. These sites ranged from $12-59 \mathrm{ppb}$.

\section{Mountain Pass Region}

The Mountain Pass sediments show very few high uranium values. The maximum concentration of uranium is $4.5 \mathrm{ppm}$, the lowest $0.6 \mathrm{ppm}$, and the average $2.0 \mathrm{ppm}$. Uranium in water averaged 5 to $6 \mathrm{ppb}$ with the lowest $1.5 \mathrm{ppb}$ and the highest 30 ppb. Even though there are high levels of thorium and the rare earths in the area, the uranium does not correlate with them. Thorium to uranium ratios are generally greater than five. 


\section{Other Elements}

In the alluvial areas on both sides of the cerbat Mountains, measurements of mercury greater than 1500 ppm were observed in several places. High values of silver were observed in the Precambrian granite in the Cerbat Mountains where there is a silver mine.

High levels of arsenic were observed in the Goodsprings District and high levels of zinc were seen in both the Goodsprings District and in the cerbat Mountains.

\section{ACKNOWLEDGMENTS}

The data herein are the cumulative result of effort by many individuals, to numerous to mention, without whose support this report would not have been possible. LLL geologists assisting in this report are: D. Leach, K. Puchlik, D. Peifer, and K. Knauss. The author fielded the sampling program and was assisted by students D. Cazes and M. Knowlton. Processing and analysis of the sediment, rock, and water samples were performed under the direction of c. Smith; processing and inventory control were the responsibility of W. Hutchin, R. Van Konynenburg performed neutron activation analysis. E. Peck and $A$. Langhorst conducted emission spectrometry, and R. Lim was responsible for special chemistries. G. McMillan developed and supervised data processing and data base management functions were performed by $B$. Gumm. Special thanks go to D. Peifer, R. Carpenter, L. Manchester and J. Attebery for the data tables, histograms, overlays, and report coordination. Ground water site selection, sample acquisition, and field measurements were provided by the Desert Research Institute. Sincere appreciation is also expressed to the land owners, Forest Service, and Bureau of Land Management personnel who granted access to the lands under their control so that the survey could be completed. The author gratefully acknowledges the hard work and patience of J. L. White and D. Taasevigen who typed the manuscript. 


\section{REFERENCES}

1. K. P. Puchlik, Raach Lake Basin Orientation Study, Nevada; Lawrence Livermore Laboratory Hydrogeochemical Reconnaissance, 1-P (1977), GJBX-48(78).

2. K. P. Puchlik, "Collection of Wet and Dry stream sediment Sampling", from the Symposium on Hydrogeochemical and Stream Sediment Sampling; Grand Junction, Colorado, Lawrence Livermore Preprint UCRL-79246 (1977), GJBX-77(77).

3. C. F. Smith, Instrumental Neutron Activation Analysis for the NURE Bydrogeochemical Survey; Lawrence Livermore Laboratory, Rept. UCRL-79709 (1978) (to be published).

4. R. Gunnink and J. B. Niday, Computerized Quantitative Analysis by Gamma Ray Spectroscopy, Description of the GAMANAL Program; Lawrence Livermore Laboratory, Rept. UCRL-51061 Vol.1 (1972).

5. R. E. Heft and W. H. Martin, NADAS and MERGE-Computer Codes for Processing Neutron Activation Analysis Data; Lawrence Livermore Laboratory, Rept. UCRL-52245 (1978) (to be published).

6. G. G. MCMillan and R. D. Carver, NURAB - A system for Processing Neutron Activated Samples; Lawrence Livermore Laboratory, Rept. UCRL-80259 (1978), (to be published).

7. D. F. Hewett, Geology and Ore Deposits of the Goodsprings Quadrangle, Nevada; usgs Prof. Paper 162 (1931).

8. D. F. Hewett, Geology and Mineral Resources of the Ivanpah Quadrangle, California and Nevada; USGS Prof. Paper 275 (1956).

9. I. J. Winograd and W. Thordarson, Hydrogeologic and Hydrogeochemical Eramework, South Central Great Basin, Nevada and California with special reference to the Nevada Test site; usgs prof. Paper 712-c (1975).

10. R. L. Naff, G. B. Maxey and R. E. Kaufmann, Interbasin Groundwater Flow in Southern Nevada; Nevada Bureau of Mines and Geology, Rept. 20 (1974).

11. C. R. Longwell, E. H. Pampeyan, B. Bowyer and R. J. Roberts, Geology and Mineral Deposits of Clark County, Nevada; Nevada Bureau of Mines Bull. 62 (1965).

12. J. C. Olson, D. R. Shawe, L. C. Pray and W. N. Sharp, Rare Earth Mineral Deposits of the Mountain Pass District, San Bernardino County, California; usgs Prof. Paper 261 (1954). 
13. R. E. Anderson, Chemistry of Tertiary Volcanic Rocks in the Eldorado Mountains, Clark County, Nevada and Comparisons with Rocks from near by area; USGS Jour. Res. Vol. 6, No. 3, May-June (1978).

14. R. B. Barton, Jr, and C. H. Behre, Jr., Interpretation and Evaluation of the Uranium Occurrences Near Birdsprings, Nevada; USACE RME - 3119 (1954).

15. C. W. Jennings, California Division Mines and Geologic Map of California; 1:250,000 kingman Sheet (1961).

16. E. D. Wilson and R. T. Moore, Geologic Map of Mohave County, Arizona; Arizona Bureau of Mines, University of Arizona (1959).

17. L. J. Garside, Radioactive Mineral Occurrences in Nevada; Mackay School of Mines, University of Nevada Bull. 81 (1973).

18. L. T. Larson and L. H. Beal, Great Basin Geologic Framework and Uranium Favorability, Final Report; Mackay School of Mines, University of Nevada, Work performed under: Bendix Field Engineering Corporation, GJBX-36(78).

19. O. M. Hart, Uranium Investigations in Mohave County, Arizona; USAEC, Salt Lake Branch Division of Raw Materials RME 2029 (1955).

20. A. P. D'Silva, M. A. Floya and W. J. Haas, Jr., Multilaboratory Analytical Quality Control for the bydrogeochemical and Stream Sediment Reconnaissance; Published monthly by Ames Laboratory, Iowa State University Press Ames, Iowa, DOE NTIS.

21. G. S. Gouett, พ. Goodfellow, R. Chapman and C. Chork, "Exploration Geochemistry-Distribution and Recognition of Anomalies"; Math. Geol. 7, 5-6 (1975). 


\section{BIBLIOGRAPHY}

Albritton, C. G., Jr., Richards, A., Brokaw, A. L., and Reinemund, J. S., 1954, Geologic Controls of Lead zinc Deposits in Goodsprings (Yellowpine) District, Nevada; U.S. Geol. Survey Bull. 1010, 111 p.

Anderson, R. E., 1969, Notes on the Geology and Paleohydrology of the Boulder City Pluton, Southern Nevada, in Geological Survey Research 1969, Chap. B: US Geol. Survey Prof. Paper 650-B.

Baroch, C. T., 1965a, Thorium, in Mineral Facts and Problems, U.S. Bur. Mines Bull. 630, 946-959.

Barrett, D. C., and Magleby, D. N., 1954, Airborne Radiometric survey, Kern and San Bernardino Counties, California, and Nye County, Vevada, U.s. Atomic Energy Comm. RME-2015, 17 p.

Barton, R. B., Jr., 1956, "Fixation of Uranium in the Oxidized Base Metal ores of the Goodsprings District, Clark County, Nevada," Econ. Geol, , 51, p. 178-191.

Behre, C. H., Jr., and Barton, R. B., Jr., 1953, Interpretation and Valuation of Uranium Occurrences in the Bird spring and Adjacent Hining Districts, Nevada, Progress Report, U.S. Atomic Energy Comm. RME-3057, 7 p.

Bingler, E. C., and Bonham, H. F., Jr., 1972, "Reconnaissance Geologic Map of the McCullough Range and Adjacent Areas, Clark County, Nevada," Nevada Bur. Mines and Geology Map 45.

Brokaw, A. L., 1944, Green Monster Mine, Clark County, Nevada, U.s. Geol. Survey open-file report.

Callaghan, E., 1939, Geology of the Searchlight District, Clark county, Nevada, U.S. Geol. Survey Bull. 906D, p. 135-188.

Carlisle, D., 1978, The Distribution of Calcrete and Gypcrete in the SouthWestern United States and their Uranium Favorability Based on the Study of Deposits in Western Australia in Southwestern Africa (NAMIBIA), GJBX-2978.

Coats, R. R., 1955, Uranium and Certain other Trace Elements in Felsic Volcanic Rocks of Cenozoic Age in Hestern United States, in Page, L. R., and Others, Contributions to the Geology of Uranium and Thorium, U.S. Geol. Survey Prog. Paper 300, p. 75-83.

Cook, E. F., 1960, "Great Basin Ignibrites (Nevada and Utah), in Geology of East Central Nevada," Intermountain Assoc. of Petroleum Geologists Guidebook, 1lth Ann. Field Conf., p. 134-141. 
Dings, M. G., 1952, The Wallapai Mining District, Cerbat Mountains, Mojave County, Arizona, U.S. Geol. Survey Bull. 978-E.

Evans, J. R., 1958, Geology of the Mescal Range, San Bernardino County, California, scale 1:24,000, Univ. of Southern California, unpublished M.S. thesis.

Gillespie, J. B., and Bentley, C. B., 1971, Geohydrology of Hualapai and Sacramento Valleys, Mohave County, Arizona, U.S. Geol. Survey WaterSupply Paper 1899-H., P1. 1, 1:125,000.

Glock, W. S., 1929, "Geology of the East-Central Part of the Spring Mountain Range, Nevada," Am. Jour. Sci., 5th Ser., 17, p. 325-341.

Haskell, B. X., 1959, The Geology of a Portion of the New York Mountains and Lanfair Valley, scale $1: 31,250$, Univ. of Southern California, unpublished M.s. thesis.

Hazzard, J. C., 1953, "The Goodsprings Dolomite at Goodsprings, Nevada," Am. Jour. Sci. 251, No. 9, p. 643-655.

Hewett, D. F., 1956, Geology and Mineral Resources of the IVanpah Quadrangle, California and Nevada: U.S. Geol. Survey Prof. Paper 275.

Hewett, D. F., 1923, "Carnotite in Southern Nevada," Eng. and Mining Jour., 115, No. 5, p. 232-236.

Hill, J. M., 1912, Yellow Pine Hining District, Clark County, Nevada, U.s. Geol. Survey Bull. 352. Fig. 7, 1:21; 860 .

Lausen, C., 1931, "Geology and Ore Deposits of the Oatman and Katherine Districts, Arizona," Ariz. Bur. Mines Geol. Ser. 6, Bull. 131.

Lee, W. T., 1908, Geologic Reconnaissance of a Part of Western Arizona, U.S. Geol. Survey Bull. 352. Fig. 7, 1:21, 860 .

Longwell, C. R., 1929, Geology of the Muddy Mountains, Nevada, U.S. Geol. Survey Bull. 798, 152 p.

Longwe1l, C. R., 1963, Reconnaissance Geology between Lake Mead and Davis Dam, Arizona-Nevada, U.S. Geol. Survey Prof. Paper 374-E.

Lovering, T. G., 1954, Radiaactive Deposits of Nevada, U.S. Geol. Survey Bull. 1009-C, $106 \mathrm{p}$.

Malan, R. C., and Sterling, D. A., 1969, A Geologic study of Uraniun Resources in Precambrian Rocks of the Western United States, U.S. Atomic Fnergy Comm. ABC-RD-9, 54 p.

Metzger, D. G., and Loeltz, O. J., 1973, Geohydrology of the Needles Area, Arizona, California and Nevada, U.s. Geol. Survey Prof. Paper 486-J, $53 \mathrm{P}$. 
Noble, D. C., 1972, "Some Observations on the Cenozoic Volcano Tectonic Evaluation of the Great Basin, Western United States," Earth and Planetary Sci., Letters, 17, No. 5, p. 142-150.

Nolan, T. B., 1943, The Basin and Range Province in Utah, Nevada and California, U.S. Geol. Survey Prof. Paper 197-D.

Olson, J. C., and Hinrichs, E. N., 1960, Reconnaissance of Beryl Bearing Pegmatites in the Ruby Mountains and Other Areas in Nevada and Northwestern Arizona, U.S. Geol. Survey Bull. 1082-D.

Peirce, H. W., Keith, S. B., and wilt, J. C., 1970, Coal, Oil, Natural Gas, Belium and Uranium in Arizona, Ariz. Bur. Mines Bull. 182, 289 p. Ransome, F. L., 1907, Preliminary Account of Goldfield, Bullfrog and other Mining Districts in Southern Nevada, U.S. Geol. Survey Bull. 303. Ransome, F. L., 1923, Geology of the Oatman Gold District, Arizona, U.S. Geol. Survey Bull. 743, 58 p.. map.

Rosholt, J. N., Jr., Prijana, and Noble, D. C., 1971, "Mobility of Uranium and Thor ium in Glassy and Crystallized Silicic Volcanic Rocks," Econ. Geol., 66. p. 1061-1069.

Rush, R. E., and Huxel, C. J., Jr., 1966, Ground-Water Appraisal of the Eldorado-Piute Valley Area, Nevada and California, Nevada Dept. Conser. and Nat. Resources, Water Resources-Reconn. Serv, Rept. 36, 29 p. Schrader, F. C., 1909, Mineral Deposits of the Cerbat Range, Black Mountains and Grand Wast Cliffs, Mohave County, Arizona, U.S. Geol. Survey Bull. 397.

Schrader, F. C., 1916, Geology and Ore Deposits of Mohave County, Arizona, AIME Bu11. 119.

Schrader, F. C., 1916, "The Ore Deposits of Mohave County, Arizona," Min. Sci. Press, 113, No. 21, p. 733-737.

Thomas, B. E., 1949, "Ore Deposits of the Wallapai District Arizona," Econ. Geol., 44, No. 8, Fig. 2, 1:72,000.

Thomas, B. E., 1953, "Geology of the Chloride quadrangle, Arizona," Geol, Soc. Amer. Bull., 64, No. 4, pl. 1, 1:125,000.

vander burg, w. O., 1937, Reconnaissance of Mining Districts in Clark County, Nevada, U.S. Bur. Mines Inf. Circ. 6964.

Volborth, A., 1962, "Allanite Pegmatites, Red Rock, Nevada, Compared with Allanite Pegmatites in Southern Nevada and California," Econ. Geol., 57, p. 209-216. 
Volborth, A., 1973, Geology of the Granite Complex of the Eldorado, Newberry, and Northern Dead Mountains, Clark County, Nevada, Nevada Bur. Mines and Geol.,. Bull. 80, 40 p.

Wilson, E. D., and Moore, R. T., 1959, Geologic Map of Mohave County, Arizona, Univ. Ariz., Ariz. Bur. Mines, scale 1:375,000. 
APPENDIX A

DATA ORGANIZATION AND DEFINITIONS

A-1 


\section{DATA PRESENTATION}

\section{Organization}

The numerical results of this reconnaissance survey are presented in three hardcopy tables (Appendix B), in microfiche tables (back cover pocket), and on six vellum overlays (back cover pocket). In addition, frequency histograms and cumulative frequency plots of the logarithm of the uraniun and thorium concentrations a:d water conductivities plotted on the overlays are included in the back of Appendix $A$.

\section{Hardcopy Tables}

Selected results of this investigation are presented in the three tables in Appendix B. Additional data on the trace elements content for each of the samples is reported in the microfiche tables. The titles and data reported in each of the three tables is given below.

Sediment analysis, dry and stream sites given in Table B-1

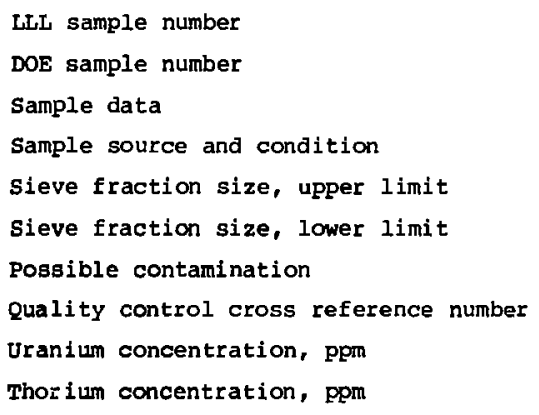

Water analyses; rivi, stream and lake sites given in Table B-2.

LLL sample number

DOE sample number

Sample date

sample source and condition

Water Temperature, ${ }^{\circ} \mathrm{C}$

pH weter

A-2 
Specific conductance, $\mu$ mho/cm

rotal alkalinity

Phenolphthalein alkalinity

Possible contamination

Uranium concentration, ppb

Quality control cross reference site number

Water analyses; springs and wells given in Pable B-3.

LLL sample number

DOE sample number

Sample date

Sample source and condition

Water temperature, ${ }^{\circ} \mathrm{C}$

Well depth-type-casing

pH meter

Specific conductance, $\mu \mathrm{mho} / \mathrm{cm}$

Total alkalinity

Phenolphthalein alkalinity

possible contamination

uranium concentration, ppb

Quality control cross-reference number

\section{Microfiche Tables}

The additional element data gathered for each sample are presented in tables on microfiche film. These tables contain data from neutron activation analyses, special chemistry, and emission spectra analyses. The table titles are exactly as in the hardcopy tables, and the columnar entries of the hardcopy tables are repeated as the first part of each microfiche table. This is followed by the element values arranged in alphabetical order according to the element's proper name. Because of the amount of data, the tables are subdivided into several parts presented on separate pages.

\section{Overlays}

Full-size vellum overlays for use with National Topographic Map Series (NTMS) $1: 250,000$ scale $1^{\circ} \times 2^{\circ}$ quadrangle are located in the rear pocket of this report. These may be used with the commercially available NTMS map 
for visual display of the sampling site locations and uranium concentration relative to local geographic features. The WTMS map name and number is given on the overlay. To limit the number of overlays that mist be generated for each map, the information presented has been divided into two major classes waters and sediments. The site number uranium concentration and thorium concentration of each sample are plotted on separate sheets for each class. Different sample site types (stream vs spring or well water, or wet vs dry sediment) are distinguished by using different symbols in association with the site number. The site type symbol is plotted over the geographic location with the site number plotted beside it. The corresponding concentration range value is indicated in a separate overlay by a symbol whose shape and size varies with the range value. The symbol set employed here is a slightly modified version of that employed by the Geological survey of Canada in their hydrogeochemical surveys. Two sets of ranges are employed because the average uranium trace element concentration is nearly a factor of $10^{3}$ larger in sediments than in natural waters. The range assignments are shown below.

\section{Water Samples}

Uranium (total) concentrations

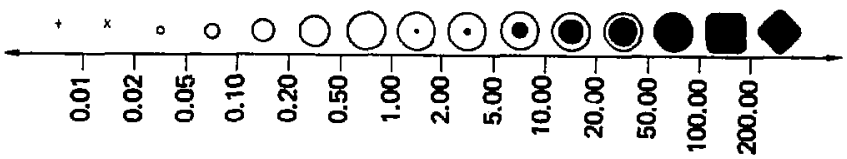

Parts per billion (ppb) by weight

+ Less than $0.01 \mathrm{ppb}$ (or not detected)

Greater than $200 \mathrm{ppb}$

Fig. A-1 Uranium concentrations in water samples. 


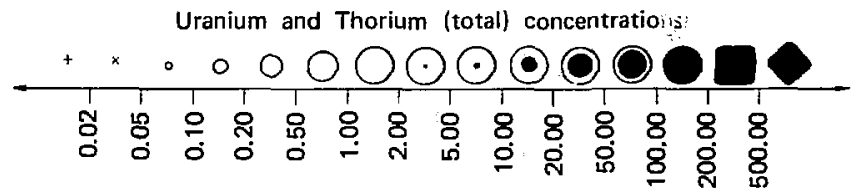

Parts per million (ppm) by weight

+ Less than 0.02 ppm (or not detected)

Greater than $500 \mathrm{ppm}$

Fig. A-2 Uranium concentration in sediment samples.

Overlay 1A. Site Locations, Water Samples

Overlay 1B. Total Uranium Concentrations, Water Samples

Overlay 1C. Field Conductivity, Water samples

Overlay 2A. Site Locations, Sediment Sanples

Overlay 2B. Total Uranium Concentrations, Sediment Samples

Overlay 2C. Total Thorium Concentrations, Sediment Samples

\section{Histograms and Cumulative Frequency Plots}

Histograms and cumulative frequency plots of the uranium values shown in over lays $1 \mathrm{~B}$ and $2 \mathrm{~B}$ are given in Fig. A-3 (water samples) and $\mathrm{Fig} \cdot \mathrm{A}-4$ (sediment samples). The histogram and cumulative frecuency plot of the thorium values shown in overlay $2 \mathrm{C}$ are given in Figure A-5. The histogram and cumulative frequency plot of the water sample conductivity values shown in overlay $1 \mathrm{C}$ are presented in Figure A-6. These are presented as the logarithm of the element concentrations.

\section{DATA DEFINITIONS}

This section presents a brief explanation of the columar entries for the hardcopy and microfiche data tables.

Blanks in the data tables indicate no measurement available. Detection limits for INAA determinations are given in the text. Emission spectrometry detection limits are indicated in the data tables by the "Iess than" sign (<). 

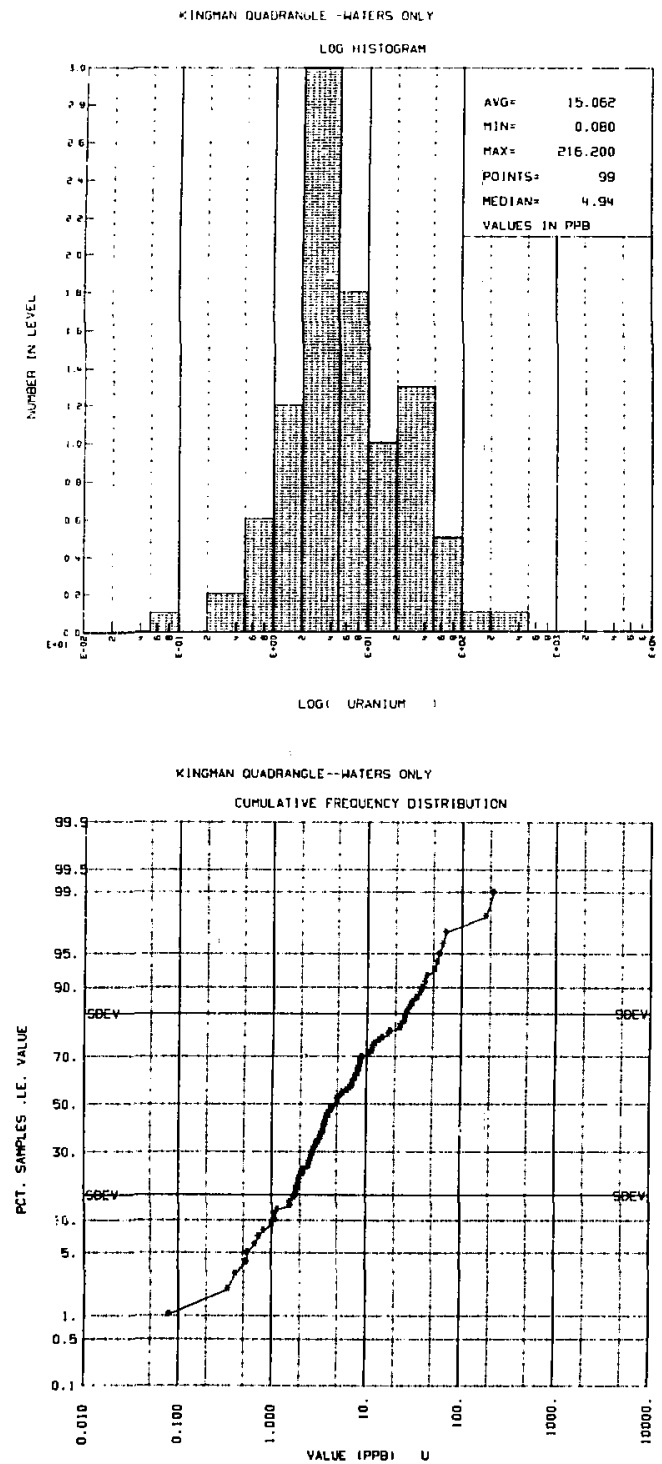

Fig. A-3 Histogram (a) and cumulative frequency distribution (b) of uranium concentrations for water samples plotted on overlay $1 B$. 


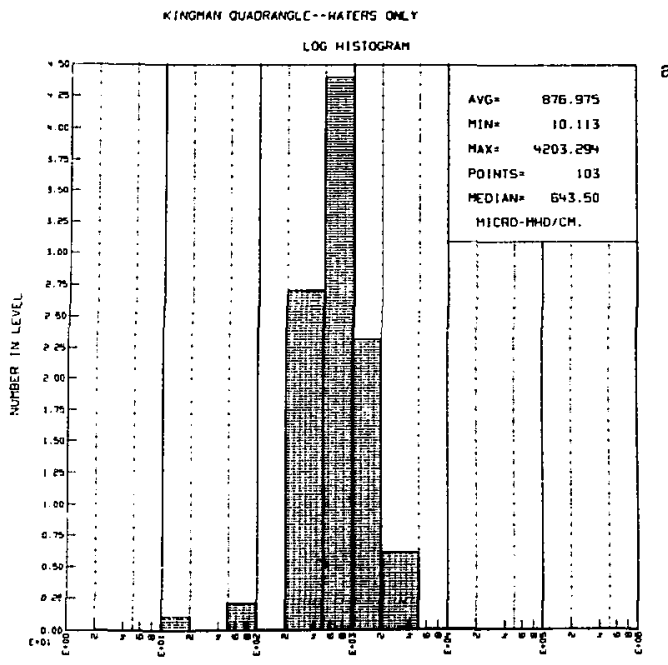

LOGI CONDUCIIVITY

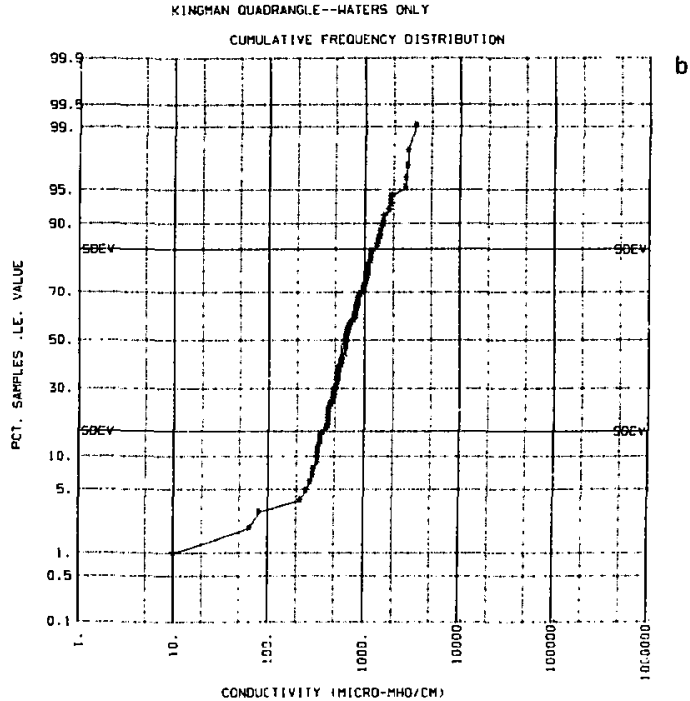

Fig. A-4 Histogram (a) and cumulative frequency distribution (b) of field conductivities for water samples plotted on overlay $1 C$. 

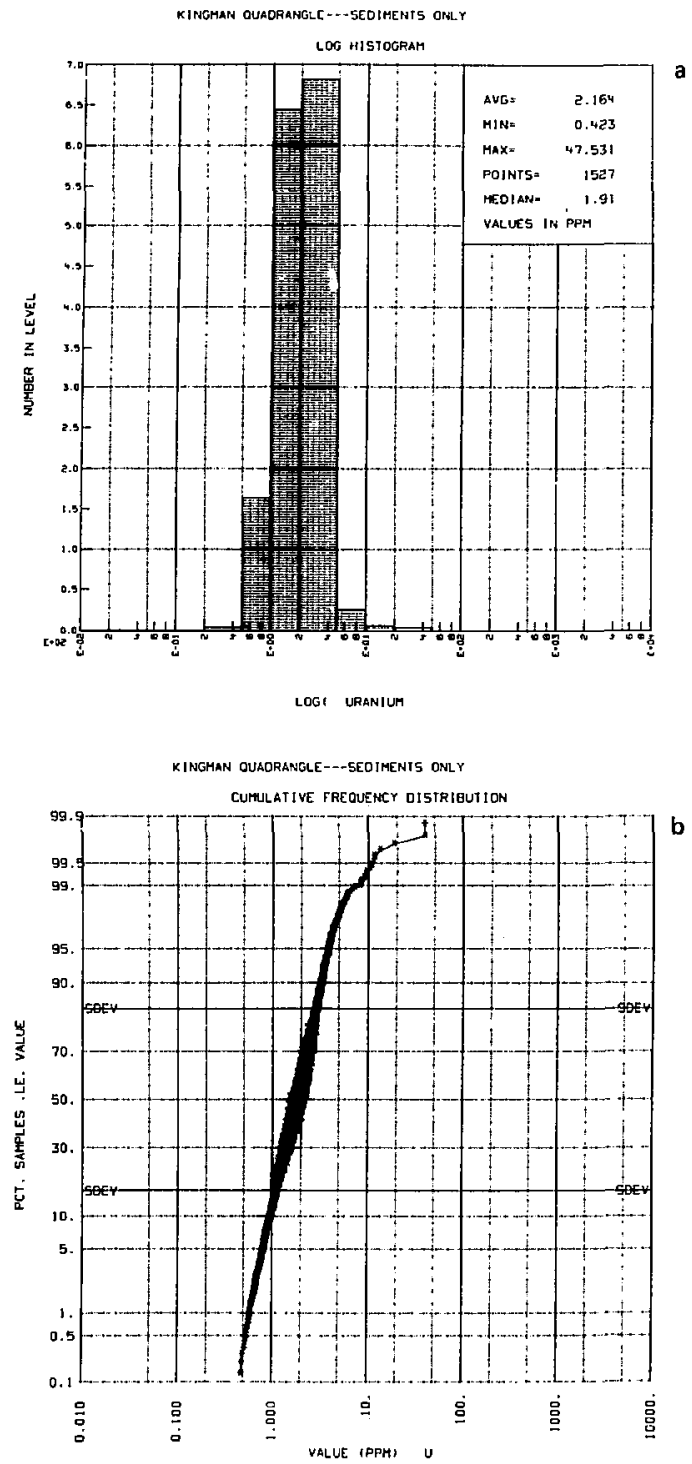

Fig. A-5 Histogram (a) and cumulative frequency distribution (b) of uranium concentrations for sediment samples plotted on overlay 28 . 

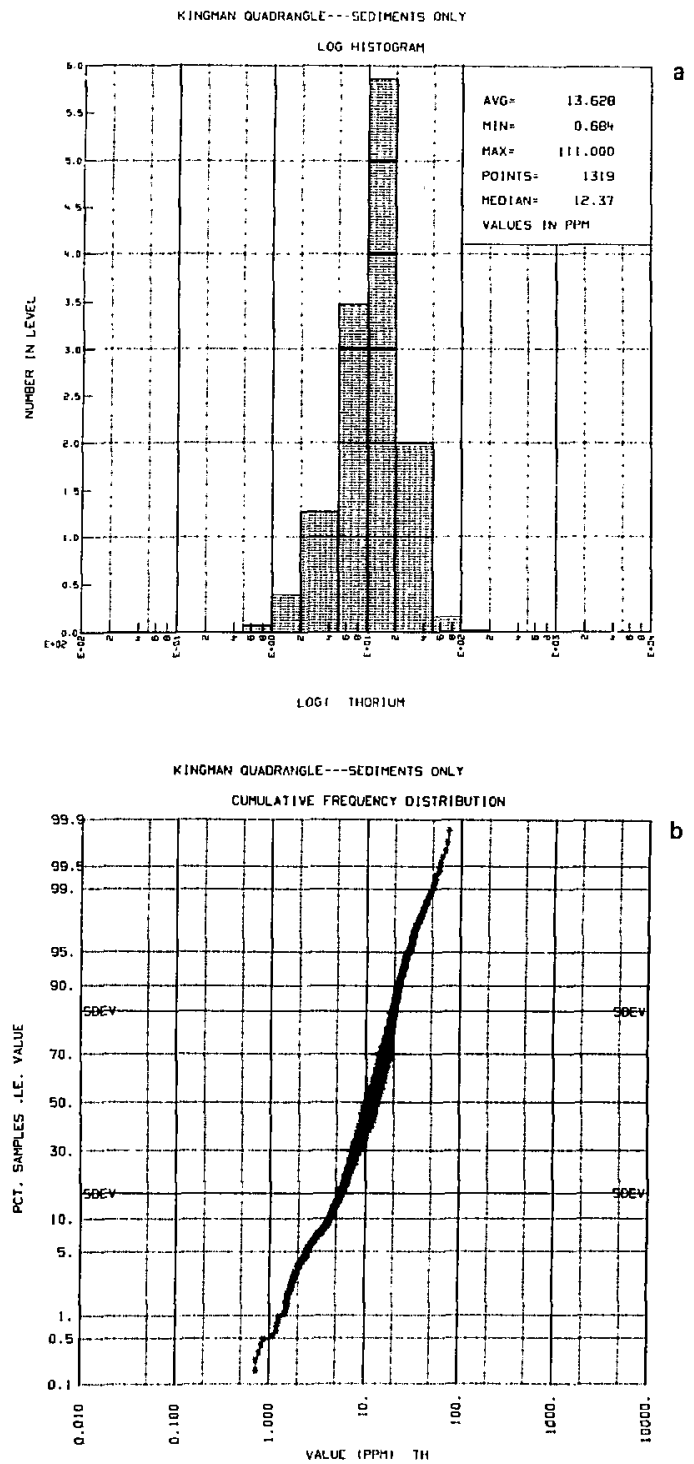

Figure A-6. Histogram (a) and cumulative frequency distribution (b) of thorium concentrations for sediment samples plot: ied on overlay $2 \mathrm{C}$. 


\section{DOE SAMPLE NUMBER}

Each analyzed field sample is assigned a DOE sample number consisting of 28 characters. Five characters (dashes) are used to delineate the number subdivision. The subdivision assignments are as follows:

Position

Description

1-2 ST, State, the two-digit Federal Information processing Standard (FIPS) designated for the state corresponding to the sample site location ( $\mathrm{AZ}=04, \mathrm{CA}=06, \mathrm{ID}=16$, $N V=32, \quad O R=41, U T=49, W A=53$ ).

4-10 L.AT, Latitude of site in decimall degrees.

12-19 LONG, Longitude of site in decimal degrees.

21 L, Originating laboratory ( $1=L L L)$

23-24 TY,

DOE Sample Type. A two-digit code describing the sample source, medium, and overall geochemical treatment (field and laboratory) prior to analysis. See DOE Sample Type Numbers below for specific assignments.

26-28 RPL, Replication code. Three-digits used to distinguish between samples from the same site. The first indicates sample type (1=sediment, 2 =water), the second identifies the field duplicate, and the third identifies analytical splits.

\section{TY, DOE SAMPLE TYPE NUMBERS}

Number

01

02

03

04

06

07

\section{Description}

Spring water sample untreated.

River or stream water sample untreated.

Well water sample untreated.

Lake or reservoir water sample untreated.

Spring water sample filtered through a $0.45 \mu \mathrm{m}$ membrane filter

and acidified to a pt of $\leq 1$ with high purity nitric acid ( $\mathrm{HNO}_{3}$ ).

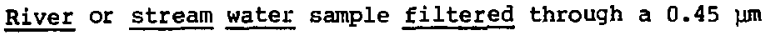
membrane filter and acidified to a pH of $\leq 1$ with high purity nitric acid $\left(\mathrm{HNO}_{3}\right)$. 
Wel1 water sample filtered through a 0.45 um membrane filter and acidified to a pl of $\leq 1$ with high purity nitric acid $\left(\mathrm{HNO}_{3}\right)$.

09

Lake or reservoir water sample filtered through a $0.45 \mathrm{~mm}$ membrane filter and acidified to a $p H$ of $\leq 1$ with high purity nitric acid ( $\mathrm{HNO}_{3}$ ).

21 Spring water sample Eiltered through a $0.45 \mathrm{~km}$ membrane Eilter.

River or stream water sample filtered through a $0.45 \mathrm{~mm}$ membrane Eilter.

We1l water sample filtered through a $0.45 \mu \mathrm{m}$ membrane filter. Lake or reservoir water sample filtered through $0.45 \mu \mathrm{m}$ membrane filter. Wet sediment sample dried at $110^{\circ} \mathrm{C}$ and sieved to the reported particle size range.

71

Lake or reservoir sediment sample dried at $110^{\circ} \mathrm{C}$ and sieved to the reported particle size range. Dry sediment sample dried at $110^{\circ} \mathrm{C}$ and sieved to the reported particle size range.

Playa sediment sample taken by hand auger over the reported depth, dried at $100^{\circ} \mathrm{C}$, and crushed to a fine powder.

Rock sample crushed and sieved to less than $250 \mu \mathrm{m}$.

\section{TEMPERATURE}

Temperature. Measurement of water temperature in situ by mercury thermometer to nearest $0.1^{\circ} \mathrm{C}$.

\section{PH}

Activity in pH units, reported to nearest $0.1 \mathrm{pH}$ unit at ambient water temperature.

\section{SP COND}

Specific conductance. Measurement in situ with a commercial conductivity meter. Reported as conductance in micromhos per cIn ( $\mu \mathrm{mho} / \mathrm{cm}$ ) normalized to $25^{\circ} \mathrm{C}$. 


\section{PHENO-ALK}

Phenolphthalein alkalinity. Measurement by titration with standard sulphuric acid to a phenolphthalein indicator endpoint (pH = B.3). Reported as an equivalent amount of $\mathrm{CaCO}_{3}$ in $\mathrm{mg} / 1$, minimum detection $20 \mathrm{mg} / 1$.

\section{TOT-ALK}

Total alkalinity. Measurement by titration with standard sulphuric acid to a bromcresol green-methyl red indicator endpoint ( $\mathrm{pH}=4.8$ ). Reported as an equivalent amount of $\mathrm{CaCO}_{3}$ in $\mathrm{mg} / 1$, minimum detection $20 \mathrm{mg} / 1$.

\section{POSSIBLE CONTAMINATION}

The major possible contaminant types are indicated according to the following code: 1. none, 2. mining, 3. agricultural, 4. incustrial, 5. sewage, 6. power generation, 7. urban, B. recreation, 9. other.

\section{URANIUM}

The trace element concentration of uranium in the sample as determined by DNC is given in parts-per-billion (PPB) by weight for waters and in parts-per-million (PPM) by weight for sediments. Where DNC values are not available, INAA determinations have been substituted and flagged with an asterisk (*). The error column contains a statistical estimate of measurement uncertainty expressed as a percentage of the concentration.

\section{OTHER ELEMENTS}

The trace element concentration of each element in the sample is given in parts-per-billion (PPB) by weight for waters and in parts-per-million (PPM) by weight for sediments. The error column (BRR) gives a numerical estimate (expressed in trace element concentration units) of the uncertainties associated with quantization of the elemental concentration. 
NUMERICAL RESULTS OF RECONNAISSANCE SURVEY 
proe b-e

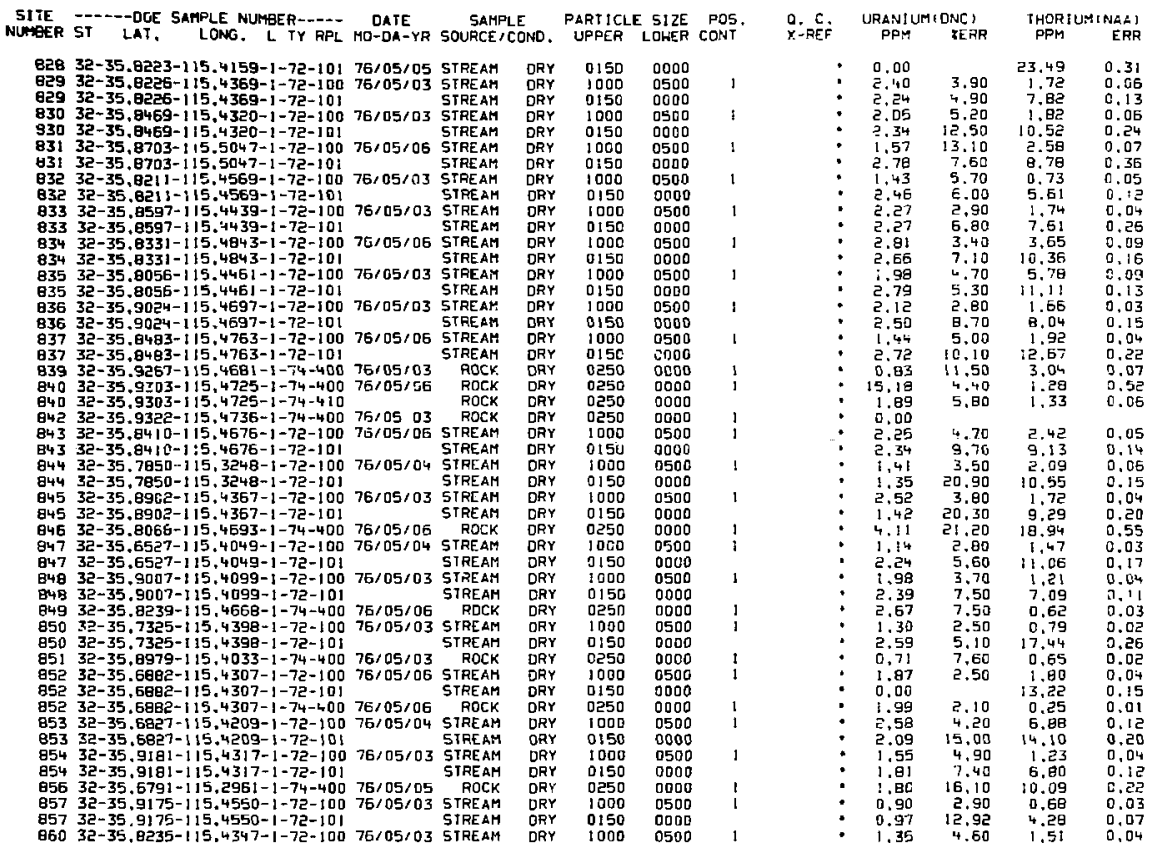




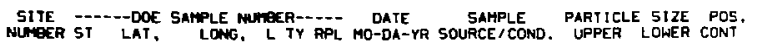

941 32-35.6563-115.3419-1-73-100 75/00/22 PLAYA 942 32-35.6865-115.3490-1-73-100 75/08/22 PLAYA $73714-35,1726-114,4339-1-70-10003 / 09 / 77$ STREAM 7372 4-35.0769-114,4281-1-70-100 03/09/77 SIREAH $737532-35,7047-114,8115-1-70-10003111177$ STREAM $73786-35.1120-114.9964-1-70-10003 / 14 / 77$ SIREAM

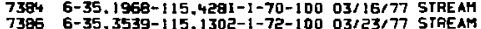

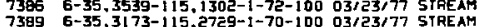
7390 6-35.1688-115.6472-1-70-100 03/24,777 STREAM 7396 6-35.3153-115.8625-1-70-100 03/27/77 STREAM 7397 6-35.3841-115.8924-1-70-100 03/07/77 STREAM 7399 6-35.4299-115.9558-1-70-100 03/27/77 STREAM $7400 \quad 6-35.4818-115.8371-1-72-100 \quad 03 / 27 / 77$ SIREAM 8993 32-35.6947-115.1006-1-70-100 03/28/77 SIREAM 9205 6-35.411日-115,4614-1-70-100 03/24/77 STREAM 9200 32-35.6245-115.0775-1-70-100 03324 9213 6-35.6209-115.0631-1-70-100 03/25/77 5TREAM 9214 6-35.5356-115.6322-1-70-100 03/27/77 STREAH 9215 6-35.4559-115,5267-1-70-100 03/27/77 STREAM $940132-35,7712-114,0529-1-72-10003 / 09 / 77$ STREAM $940232-35.8221-114.0249-1-72-100$ 03/09/77 STREAM 9403 32-35.8445-114.8187-1-72-100 03/09/77 STREAM 9405 32-35.8124-111, 7897-1-72-100 03/09/77 STREAH 9406 32- $35.7992-114,0056-1-72-10003 / 10 / 77$ STREAM 9407 32-35.8096-114,0838-1-72-100 03/10777 SIREAM 9400 32-35,7715-114.8195-1-72-100 03/10/77 STREAM 9409 32-35.7717-114.0318-1-72-100 03/09/77 STREAM $941032-35,7978-114,0797-1-72-10003 / 10 / 77$ STREAM 9411 32-35,7889-114,6055-1-72-100 03/10/77 STREAM 9413 32-35.7712-114.9003-1-72-100 03/10/77 STREAM 943 3e-35.7614-114.9003-1-72-100 03/10/77 STREAM 9415 32-35.7733-114, $0302-1-72-100$ 03110,77 5TREAH 9415 32-35.7832-114,9199-1-72-100 03/10/77 STREAM 9417 32-35,7905-114,9242-1-72-100 03/10/77 STREAM 9418 32-35,7960-114.9296-1-72-100 D3/10/77 STREAM 9419 32-35.7549-114,8488-1-72-100 03/11/77 STREAM 9419 32-35.7549-114.8488-1-72-101 5TREAM 9420 32-35.7965-114.9052-1-72-100 03/11/77 STREAM 9421 32-35,8538-114,9890-1-72-100 03/11/77 STREAM 9423 32-35.7752-115.0093-1-72-100 03/12/77 STREAM $942432-35,0061-115,1019-1-72-10003 / 12 / 77$ 5TREAM 9425 32-35.8113-115,0907-1-72-100 03/12/77 STREAM

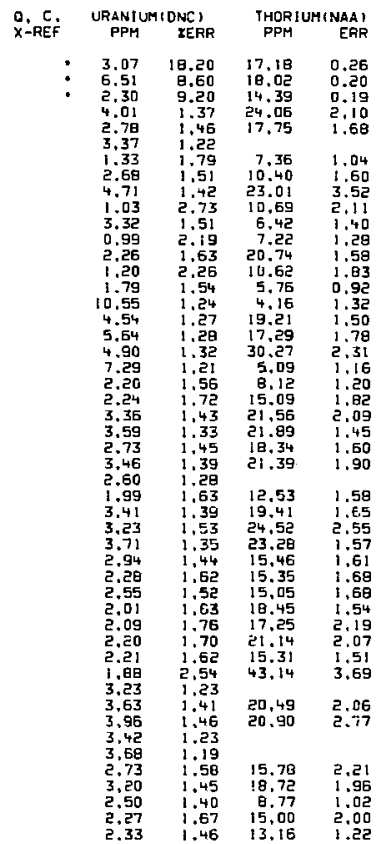


1000

$942732-35.8207-115.0517-1-72-10003 / 12 / 77$ STREAM $942932-35,6650-115,0142-1-72-10003112,77$ STREAM 9430 32-35.9739-115.1145-1-73-100 03/13/77 STREAH 9431 32-35.94!0-115.0821-1-72-100 03/13/77 STREAM 9432 32-35.9604-115.0594-1-72-100 03/13/77 5TREAM 9433 32-35.9742-115.0757-1-72-100 03/13/77 STREAM $943532-35,9650-115.0755-1-72-10003 / 13 / 77$ STREAM 9436 32-35.9155-115.12BI-1-72-100 03/13/77 5IREAM 32-35.9001-13:.1784-k-7R-100 03313/77 STREAH $944033-35,9114-115,0950-1-72-10003 / 14 / 77$ STREAM 作 9442 32-35.8927-115.1055-1-72-100 03/15/77 STREAM $944332-35,8773-115,1036-1-72-10003 / 15 / 77$ STREAM $944432-35.8752-115.0659-1-72-10003315 / 77$ STREAM $944532-35.8962-115.1553-1-72-10003 / 15 / 77$ STREAH

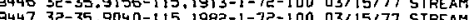
9448 5449 32-35,8175-115,1425-1-72-100 03/15/77 5TREAY 9450 3e-35.8211-115,1447-1-72-100 031 $945132-35.8502-115,0465-1-72-10003 / 15 / 77$ STREAM 9452 32-35,8583-115.0420-1-72-100 03/16/77 STREAM 9453 32-35.088-115.0324-1-72-100 03/15/77 STREAM 945. 32-35. 139-115.0273-1-72-100 03/16/7) STREAM 作 - 1000311777 STREaM 9458 32-35, 9385-115, 2374-1-72-100 03117377 5TREAM $945932-35,8601-115.2147-1-72-10003 / 17177$ STREA:1 $946032-35.6789-115,0420-1-72-10003 / 18 / 77$ STREAM $946132-35.6524-115.0291-1-72-10003 / 19 / 77$ STREAM

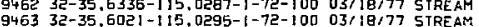
94 4 32-35,5923-115.0375-1-72-100 03/18/77 STREAM $946532-35,4443-114.8185-1-72-10003 / 18,77$ STREAM $946632-35,4416-114,8185-1-72-10003 / 19 / 77$ STREAM $94 \overline{2} 732-35.4255-114,8301-1-72-100$ 03/18/77 STREAM $946832-35,3551-114.6779-1-72-10003 / 19 / 27$ STREAM 9469 32-35.3557-114.6625-1-72-100 03/19/77 5TKEAM 9469 32-35,3557-114,6625-1-72-101 STREAH $947032-35.3381-114.6377-1-72-100$ 03/19/77 STREAM $947 ! 32-35,3255-114,6403-1-72-10003119 / 77$ STREAM $94732-35.3173-114,7296-1-72-10003 / 19 / 77$ STREAM $947332-35,2985-1 / 4,7334-1-72-10003 / 19 / 77$ STREAM

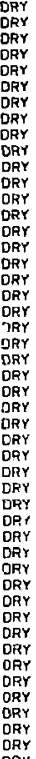

更

0500
0500
0500
0500
0500
0500
0500
0500
0500
0500
0500
0500
0500
0500
0500
0500
0500
0500
0500
0500
0500
0500
0500
0500
0500
0500
0500
0500
0500
0500
0500
0500
0500
0500
0500
0500
0500
0500
0500
0500
0500
0500
0500
0500
0500
0500
0500
0500
0500

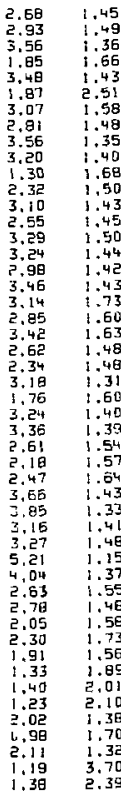

9. 95

$20.97 \quad 1.98$

$4.99 \quad 1.68$

1.90

$\begin{array}{rr}9.18 & 3.87 \\ 16.51 & 2.75\end{array}$

$14.72 \quad 1.65$

4.71
1.72

14.77
20.47

$17.86 \quad 1.36$

$22.42 \quad 2.35$

$17.57 \quad 9.45$

3.03

17.76

$16.82 \quad 3.36$

$13.55 \quad 1.36$

$9.26 \quad 0.91$

$17.55 \quad 1.76$

21. 30

12.59

14.45

$19.65 \quad 2.27$

10,76
19,92

$23.62 \quad 1.89$

$16.20 \quad 2.04$

$16.05 \quad 1.00$

$\begin{array}{lll}16.48 & 2.34\end{array}$

12.47

$\begin{array}{lll}14.78 & 1.72 \\ 10,05 & 1.61\end{array}$

1. 38

1.32

$7.28 \quad 3.96$ 
$947532-35,2572-114,7422-1-72-100$ 03/20/77 STREAM 9476 32-35.1678-1:4.6909-1-72-100 03/21/77 STREAH 9477 32-35.1708-114,7051-1-72-100 03/21,77 STREAM $947832-35,1431+114.7169-1-72-10005 / 21 / 77$ STAEAM $947932-35.1322-114.7128-1-72-10002 / 21 / 77$ STREAM $948032-35,1160-114,7132-1-72-10003 / 21 / 77$ STAEAM $949232-35,1350+114,6710-1-72-100 \quad 03 / 21,77$ STREAM 443 32-35, 1615-114,64:7-1-72-100 03/21/77 STREAM 9404 32-35.1499-134.6485-1-72-100 03/24/77 STREAM 9485 32-33.1826-114,6598-1-72-100 03/21/77 STRE.AM 9486 3r-35,1903-114,6848-1+72-100 03/21/77 STREAM 9487 33-.35.2015-114,6823-1-72-100 03:21/77 5TREAM 9486 3. 35. $3960-111,6517-1-72-100$ 03/21/77 STREAM 9439 3. $35.193,114.62971-72-10003 / 21 / 77$ STREAM

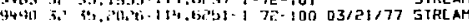
STh

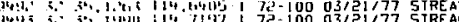

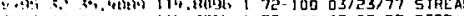
ate Mu S49. 作

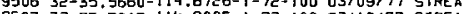
9507 3e-35,7018-114,0005-1-7e-100 03/10177 STREAM 9509 32-35.7364-114, 9509 32-35, 7023-114.8201-1-72-101 0310177 STREAM $951032-35,7430-114,8359-1-72-10003 / 10 / 77$ STREAM 9511 32-35,7285-114, 8927-1-72-100 03/10/77 STAEAM 9512 32-35,6267-1/4,8898-1-72-100 03/10/77 STREAM 9513 32-35.5323- $144.8018-1-72-10003310177$ 5TREAM $951432-35.5100-114.7638-1-72-10003 / 10 / 77$ STREAM 9515 32-35.5598-114.253 - $1-72-100033101177$ STREAH 9517 32-35,5576-114.808-1-7e-100 03/111777 STREAM $114,9666-1-72-10003 / 12 / 77$ STREAH 9519 32-35.5586-114.9666-1-72-101 STREAM

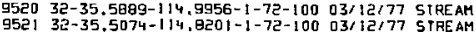

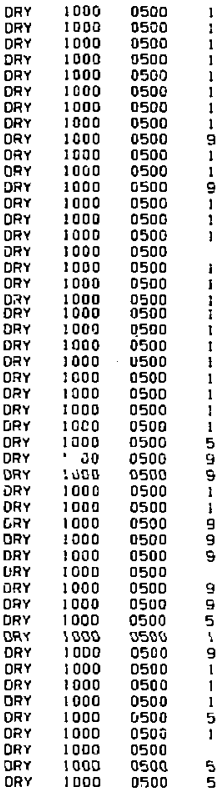
URANIUMIDNC:
PPM TERP

\begin{tabular}{|c|c|c|}
\hline .56 & $\begin{array}{r}16.19 \\
9.30 \\
13.11\end{array}$ & $\begin{array}{l}1.32 \\
1.35 \\
1.09\end{array}$ \\
\hline & $\begin{array}{r}6.41 \\
12.55\end{array}$ & $\begin{array}{l}0.96 \\
1,27\end{array}$ \\
\hline & 6.30 & 1.56 \\
\hline & $\begin{array}{l}7.41 \\
15.35 \\
31.62 \\
19.05 \\
29.49 \\
14.39 \\
17.09\end{array}$ & $\begin{array}{l}1.39 \\
1.89 \\
2.32 \\
1.92 \\
3.32 \\
1.66 \\
3.24\end{array}$ \\
\hline 5 & $\begin{array}{r}15.43 \\
14.05 \\
10.76 \\
6.49 \\
8.60 \\
14.49 \\
13.22 \\
15.81 \\
23.93\end{array}$ & $\begin{array}{l}1.37 \\
1.67 \\
1.47 \\
1.22 \\
1.49 \\
2.27 \\
1.75 \\
1.66 \\
2.20\end{array}$ \\
\hline & $\begin{array}{l}16.38 \\
16.20 \\
17.71\end{array}$ & $\begin{array}{l}1.44 \\
1.99 \\
1.79\end{array}$ \\
\hline 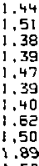 & $\begin{array}{l}14.35 \\
19.45 \\
25.46 \\
17.35 \\
14.60 \\
25.70 \\
12.86 \\
17.76 \\
15.84\end{array}$ & $\begin{array}{l}1.39 \\
1.42 \\
1.75 \\
1.92 \\
1.59 \\
2.81 \\
1.54 \\
1.82 \\
3.09\end{array}$ \\
\hline & 11.90 & 1,23 \\
\hline & $\begin{array}{l}14,20 \\
17.50\end{array}$ & $\begin{array}{l}1.59 \\
1.5 E\end{array}$ \\
\hline 4 & 18. & $\begin{array}{l}1.74 \\
1.48\end{array}$ \\
\hline
\end{tabular}


THORIUMCNAA)
PPM ERP

SITE
NUMEER ST LAT, LAMPLE NUMBER--.- DATE SAHG, L TY RPL MO-DA-YR SOURCE/COND. PAPTICLE 5 IZE POS
UPPE LUWER CONT

Q. C. URANIUMIDNE,
X-REF PPH :ERR

9522 32-35.5175-114, 732B-1-72-100 03/12/77 STREAM

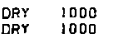

$9523 \quad 32-35.5338-114.7378-1-72-100 \quad 03 / 12 / 77$ STREAM

952E 32-35.5808-114.7895-1-72-100 03/12/77 STREAM

9527 32-35.5962-1/4.7968-1-72-100 03/13/77 STREAM

9528 32-35.5064-114,9139-1-72-100 03/13/77 STREAM

$952932-35.5988-114,8408-1-72-101$ 1

$953032-35,6061-114,84411-1--5-10003 / 13 / 77$ STREAM

951

9532 32-35.7532-134,7537-1-72-100 03/14/77 STREAM

9533 32-35.765I-114.7645-1-72-100 03/14/77 STREAM

$953432-35,7434-114,8093-1-72-100$ 03/14/77 STREAM

$953532-35,7218-114.8121-1-72-10003114177$ SIREAM

$953732-35,6610-114,7895-1-72-10003 / 14,77$ STREAM

$953832-35,3634-114,8350-1-72-10003114177$ SIREAM

9540 32-35.3049-114,

9541 32-35,3441-114,7652-1-72-100 03114,77 STREAM.

$954432-35.3430-114.9027-1-72-10003 / 15 / 77$ STREAH

$954532-35.2884-114.8744-1.72-100$ 03/15/77 STREAM

$95432-35.2771-114,8978-1-72-10003115 / 777$ STREAM

354 32-35.3110-114.9805-1-72-100 03:15

9549 32-35.3920-114,9766-1-72-100 03/15/27 5IAEAH

$955032-35,2738-114,9682-1-72-10003 / 15 / 77$ 5TREAM

I5S1 32-35.2532-114.9797-1-72-100 03/15/77 STREAM

$955232-35.2595-114.7733-1-72-100$ 03/15/77 STREAM

$955332-35.2664-114,7552-1-72-10003 / 15 / 77$ SIREAM

$95546-35.2467-114.7612-1-72-100$ 03/15/77 STREAM

9556 6-35.2271-114,7716-1-72-100 03/5777 STREAM

9557 5-35.2061-114.7579-1-72-100 03115777 SIREAH

558 6-35.1700-114,7512-1-72-100 03/15/77 STREAH

9559 5-35, 1859-114, 2397-i-72-101 STREAH

9560 32-35,5203-115,1594-I-72-100 03/16/77 STREAM

9561 32-35.5347-1/15, 1502-1-72-100 03/16/77 5TREAM $956232-35.5599-115,1574-1-72-10003116 / 77$ STREAM $956332-35.5536-115.1598-1-72-10003 / 16 / 77$ STR AM $956532-35.5761-115,1526-1-72-10003116 / 77$ STREAM 9565 6-35,4959-115, $1769-1-72-10003 / 16 / 77$ STREAM (2) 956 32-35.5082-115.1342-1-72-100 03/17/77 STPEAH $956932-35,6157-115.2484-1-72-10003 / 17,77$ STREAM STREAM OQY

1000

$\begin{array}{ll}9.90 \\ D R Y & 1000\end{array}$

1000

DRY 1000 


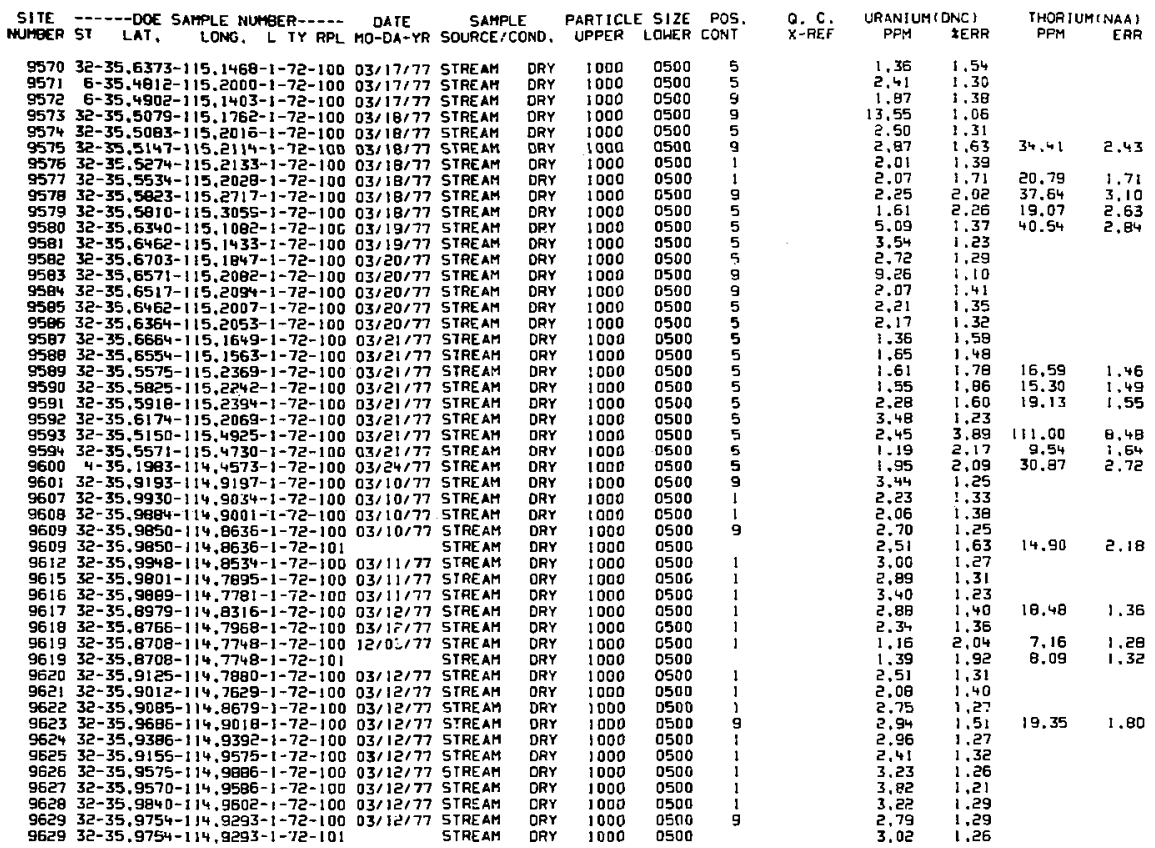




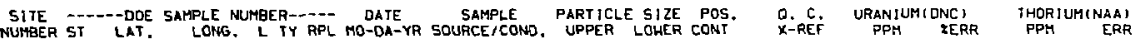

$963032-35.9618-114.9264-1-72-10003 / 12177$ STREAM DRY 10000500 $963132-35.9538-114.9321-1-72-10003 / 12 / 77$ STREAM $963232-35,8852-114,9782-1-72-100 \quad 03 / 12 / 77$ STREAM $963432-35,4730-114,9665-1-72-10003 / 13 / 77$ STREAM 作 536 32-35.4014-114.9430-1-72-100 63113/77 5TREAM $963732-35,3498-114,9872-1-72-10013 / 03 / 77$ STREAM 963日 32-35,4477-114.9110-1-72-100 03/13/77 SIREAH (3639 32-35,485:-114,8647-1-72-100 03r13/77 STREAH (9640 32-35,4676-114.0653-1-72-100 03/13/77 STREAM (1) (1) 作 9645 32-35,4921-114,7743-1-72-100 03/13/77 5TREAM $964832-35,4499-114$, , 8 日12- $1-72-100$ 03/13/77 STREAH 9649 32-35.4337-114,8916-1-72-100 03/13/77 SIREAM 作 555 32-35, $3754-114,0974-1-72-10003113177$ SIREAM 9553 32-35. -72-100 03/15/77 STREAM 作 9658 6-35.4679-115.4791-1-72-100 03/15/77 STREAM (1000 03/15/77 STREAM 作 605 $6-35,3844-115,3684-1-72-10003 / 15 / 77$ STREAM 0567 5-35.2909-115.4549-1-72-100 03/15/77 STREAM (15) 5659, 3922-115,4133-1-72-100 03115/77 STREAM 9669 6-35. $2822-115,4133-1-72-101$ STREAM 5-35,3272-115,2705-1-72-100 03/15/77 STREAM 6-35,3406-115.2625-1-72-100 03/15/77 SIREAM (957) 32-35.4796-114.7294-1-72-100 03/15/77 STREAM

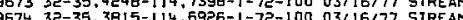
$967432-35.3915-114,639-1-75-10003161677$ STREAM 9675 $32-35,4571-114,8314-1-72-10003 / 16 / 77$ STREAM

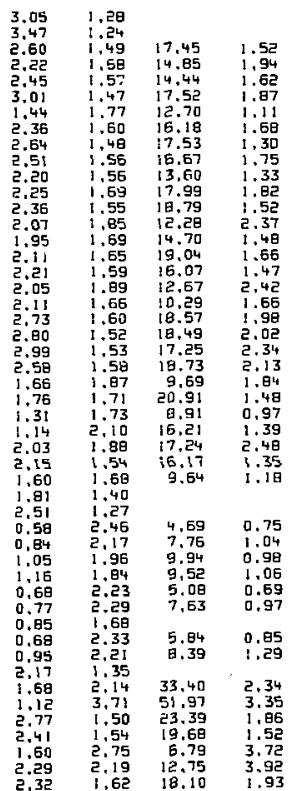




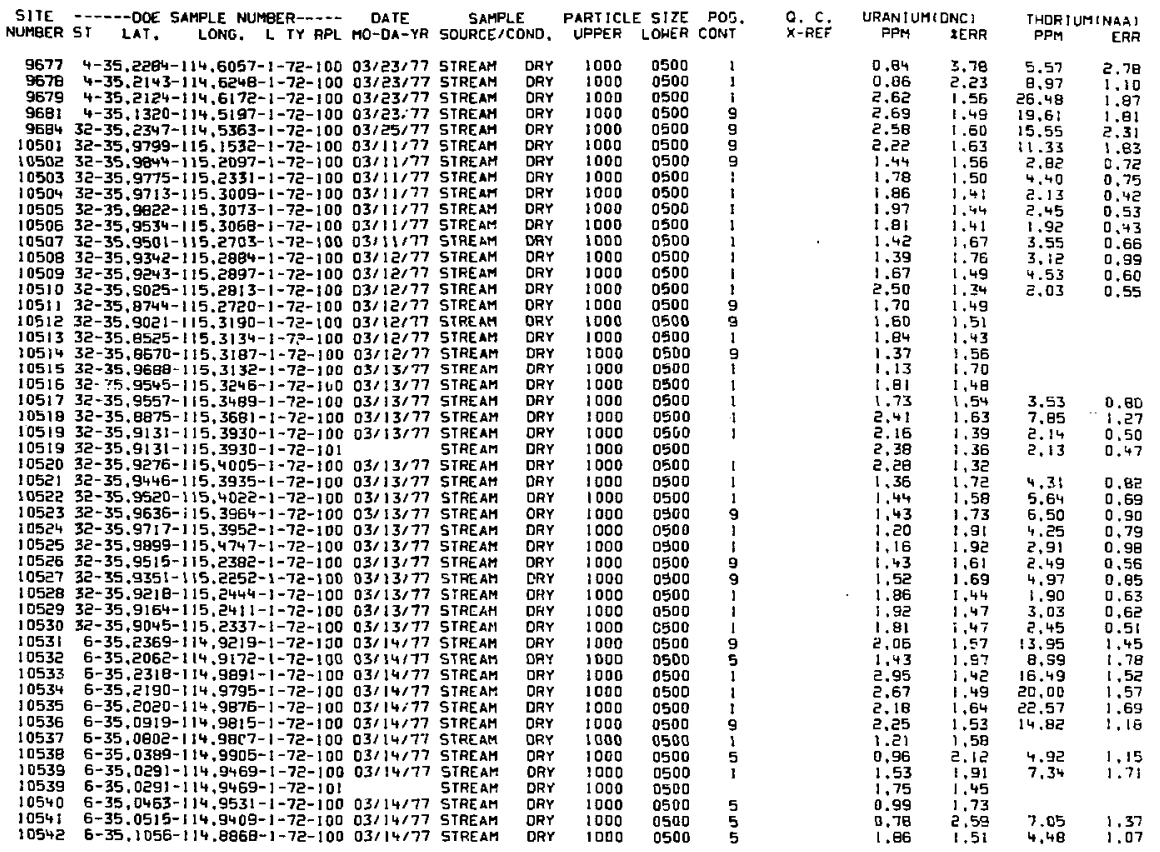




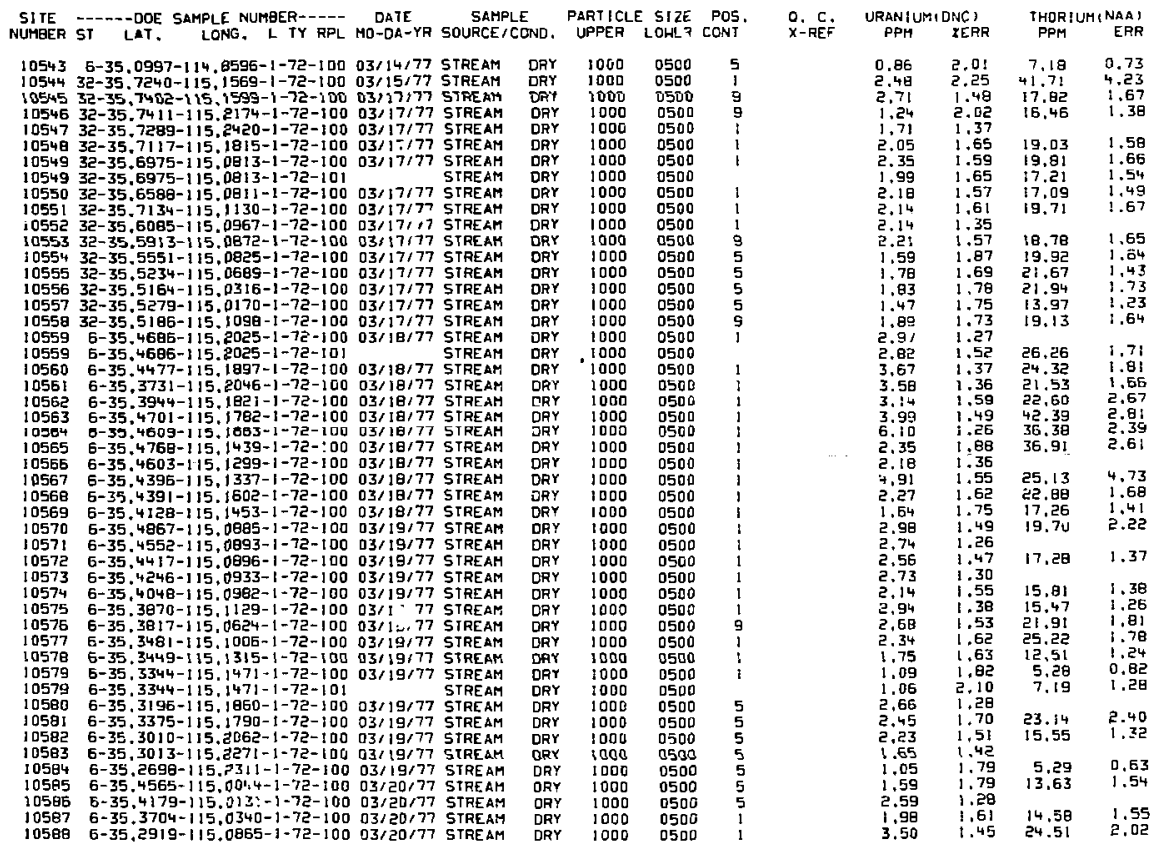




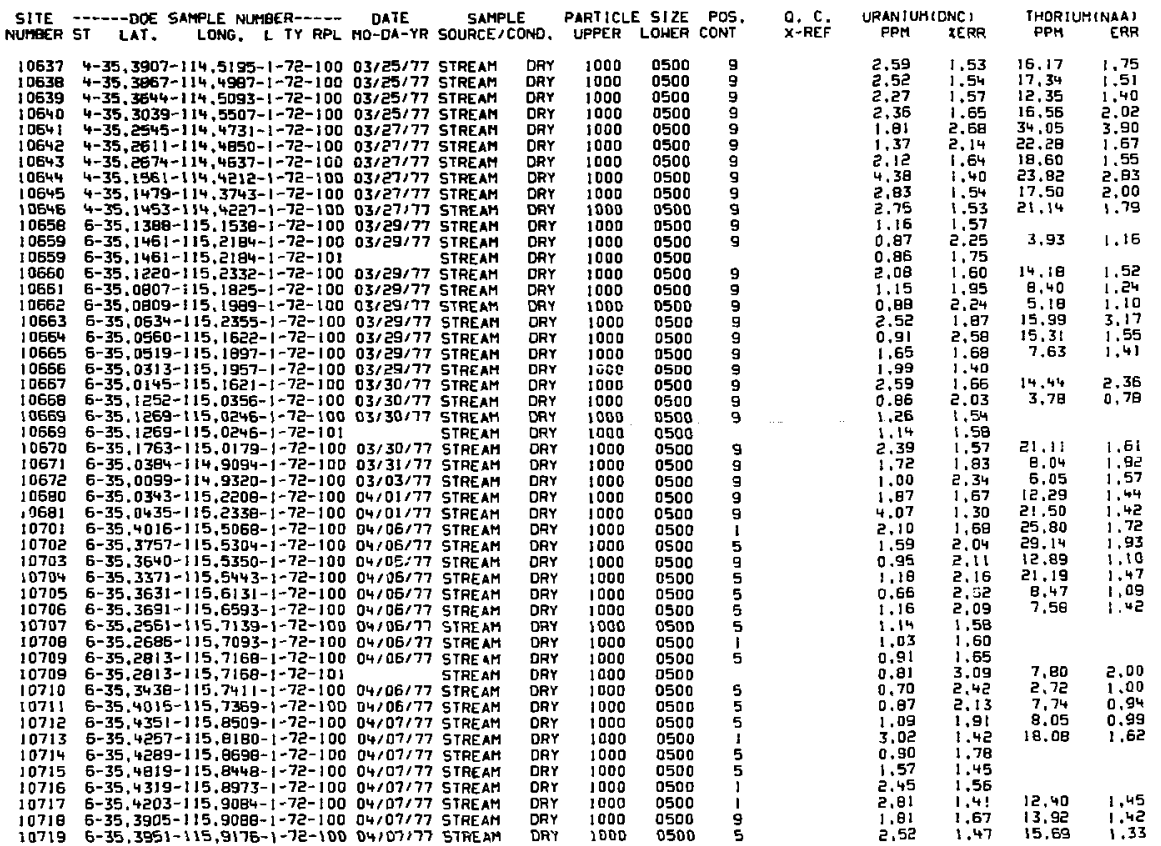




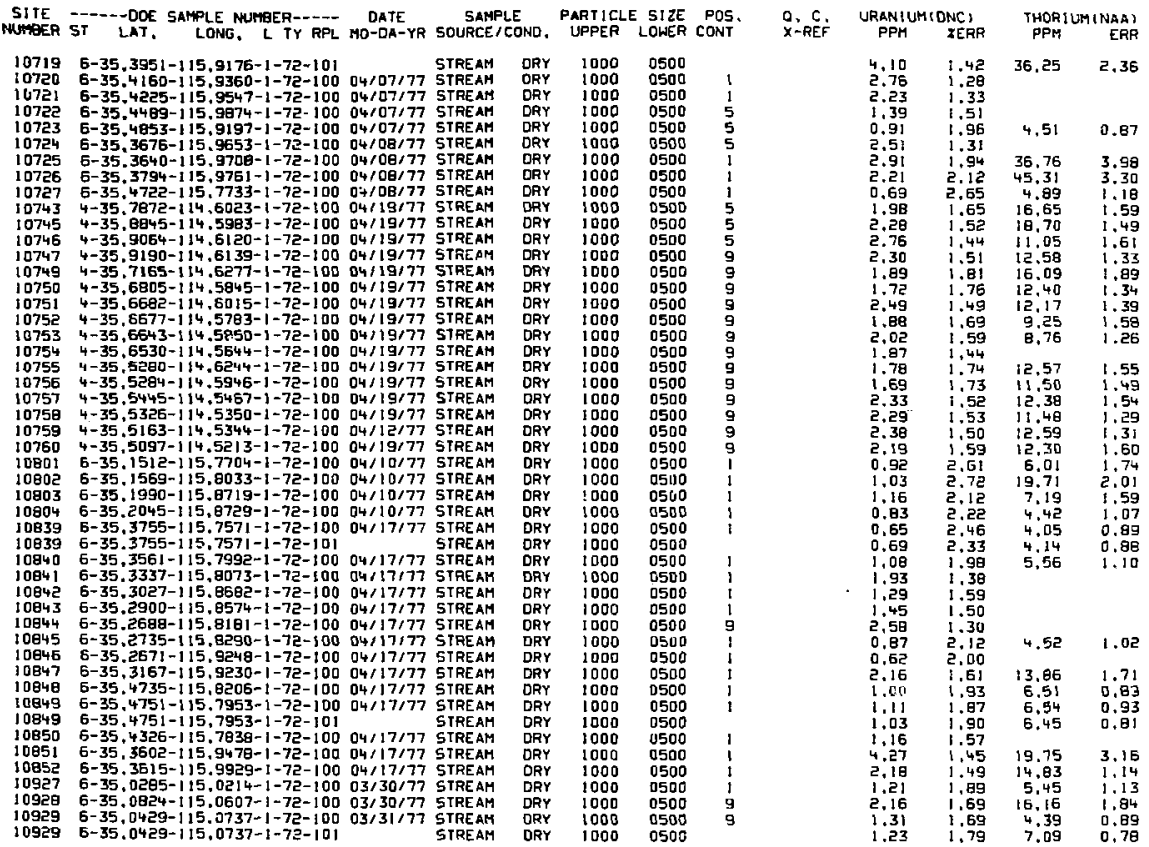




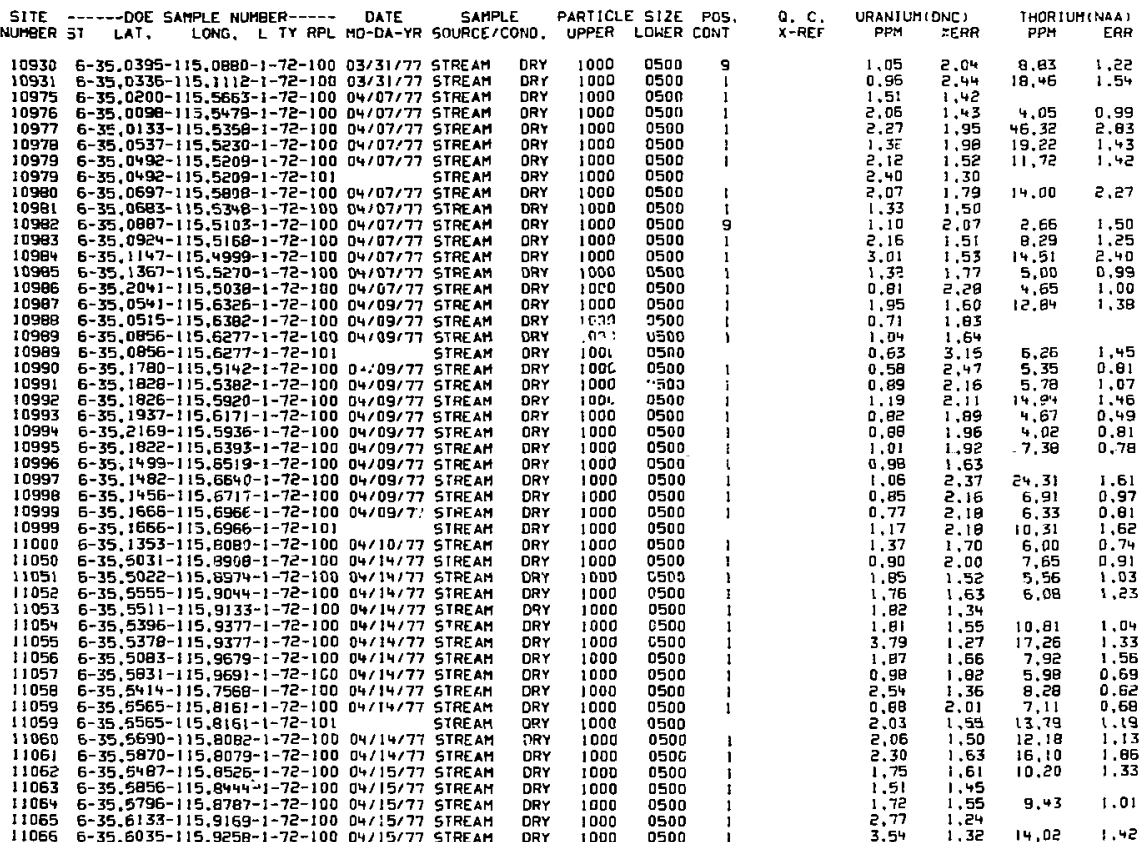




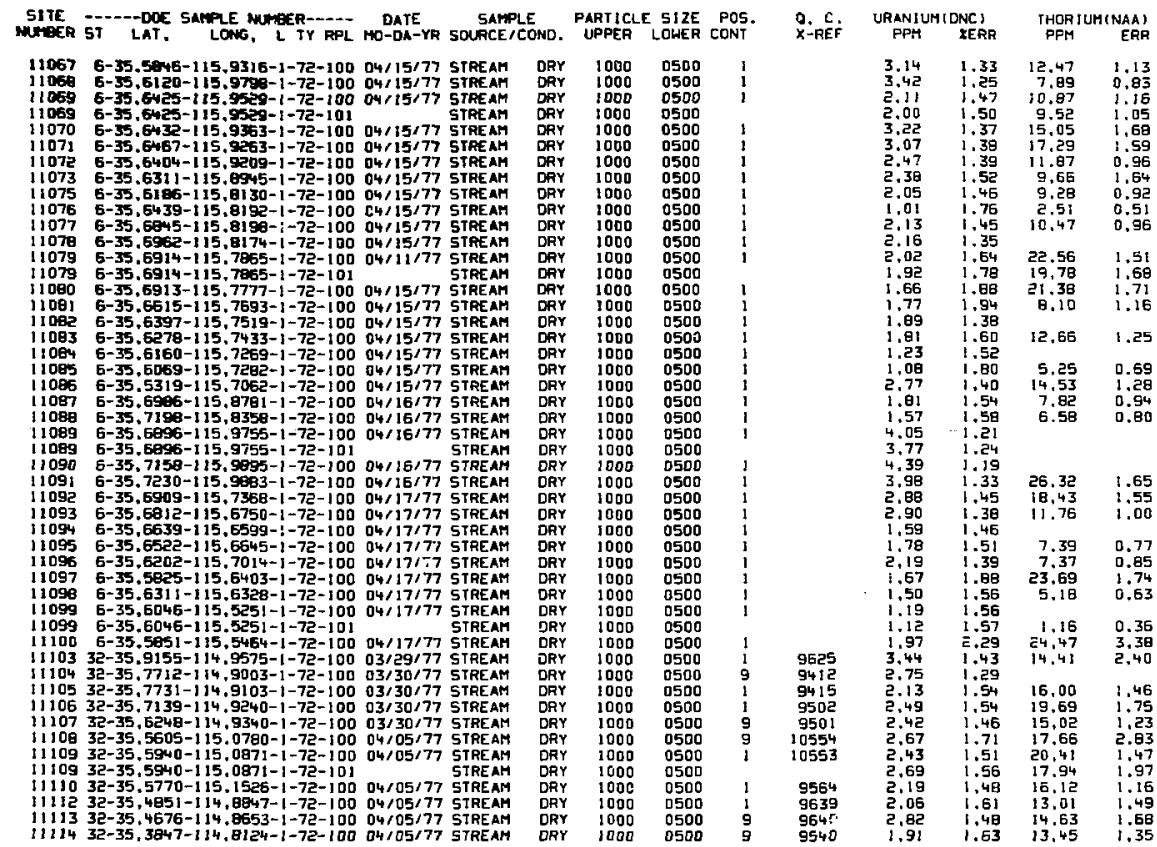




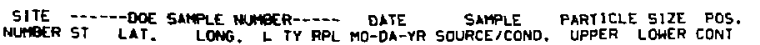
THORIUMINAA,
PPH ERR

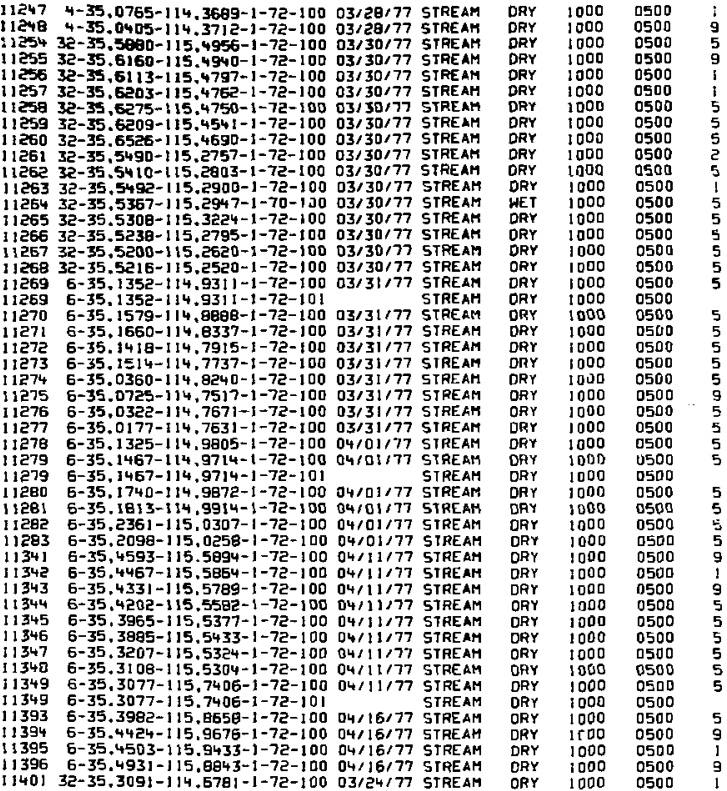

Q. C. URANIUMIDNC:

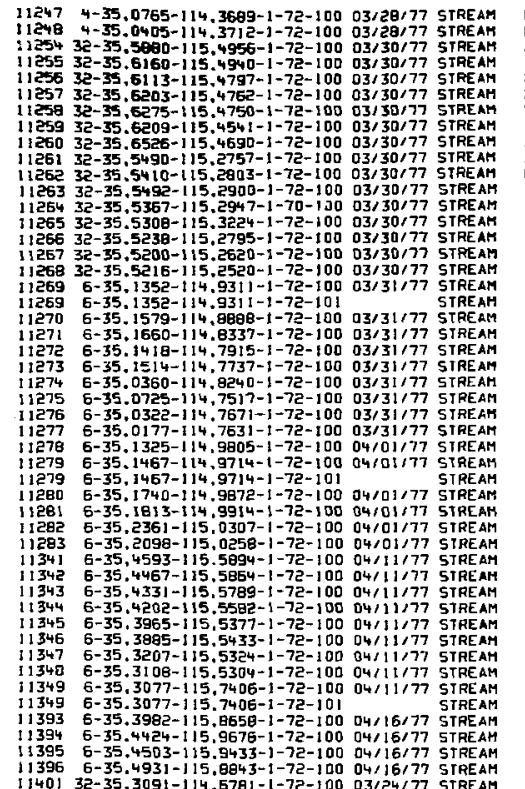

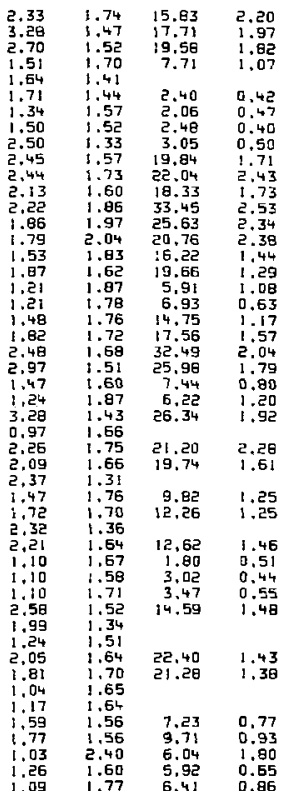




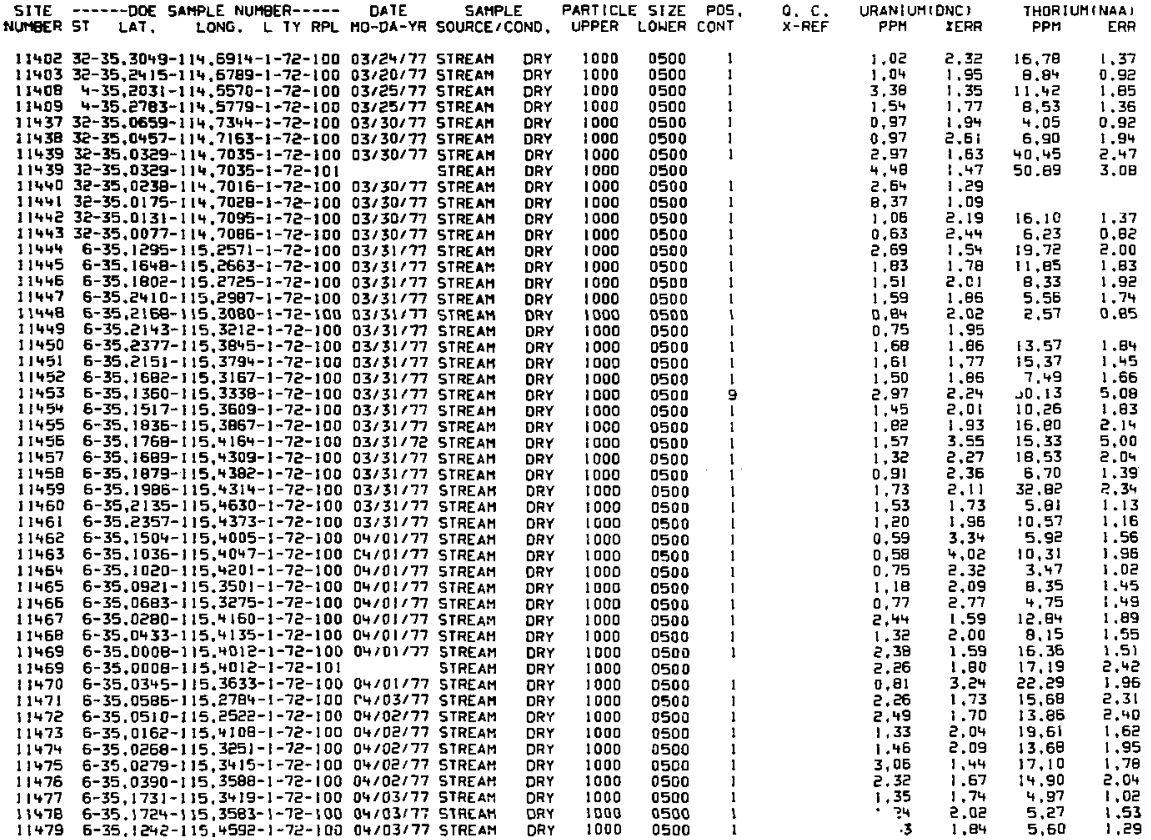




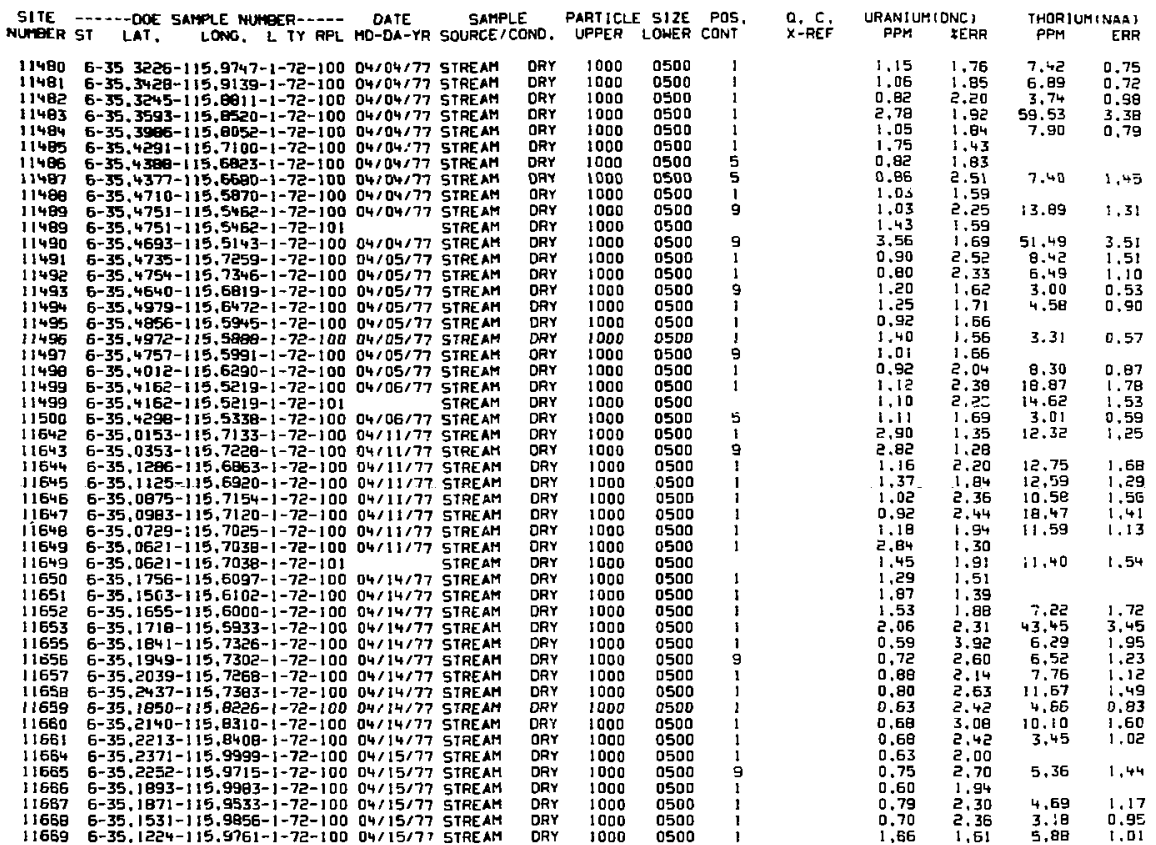




\section{(1)}

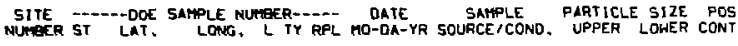

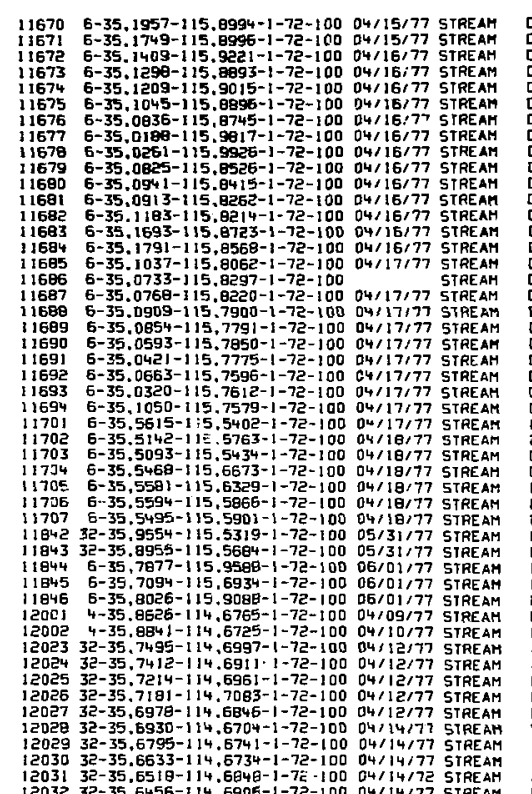

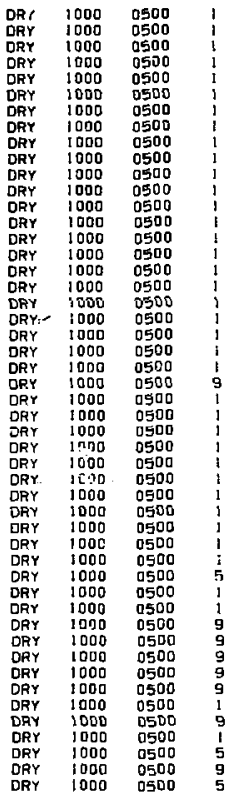

O. C,
$X-R E F$

$0.76 \quad 1.79$

$\begin{array}{ll}1.65 & 1.61 \\ 3.04 & 9.64 \\ 2.01 & 1.51\end{array}$

1.85

5.80
5.80

0.72
0.81

$\begin{array}{ll}0.81 & 2.00 \\ 3.30 & 1.24\end{array}$

3.56

1.16
.60

1.69

0.84
2.61

1.64

1.15

1.15
2.44
0.94

0.94
0.72

$1.72 \quad 1.70$
$1.29 \quad 3.0$

$\begin{array}{ll}2.40 \\ 1.05 & 1.69\end{array}$

$\begin{array}{ll}0.96 & 1.86 \\ 0.98 & 1.77\end{array}$

1.90

1.29
1.96

1.90
0.88

12934

12928

13915

$1.40 \quad 1.45$

$0.80 \quad 2.60$

$\begin{array}{ll}2.15 & 1.50 \\ 2.79 & 1.47\end{array}$

$\begin{array}{ll}2.09 & 1.62 \\ 1.52 & 1.72\end{array}$

3.14

1,91

1,69

2.35
2.03
2.25
JRANYUHI (ONC)

$\begin{array}{ll}1.31 \\ 2.41 & 1.47\end{array}$
THOR IUM (NAA)
PPM N ERP

$7.82 \quad 1.10$

$6.32 \quad 1.17$

$4.32 \quad 1.19$

$\begin{array}{ll}4.09 & 1.14 \\ 4.09 & 0.70\end{array}$

$0.57 \quad 1.15$
1.07

$\begin{array}{ll}10.92 & 2.32 \\ 12.07 & 1.77\end{array}$

$\begin{array}{ll}9.46 & 1.12 \\ 7.74 & 1.19\end{array}$

$\begin{array}{ll}5.48 & 0.94 \\ 6.60 & 1.26\end{array}$

$7.31 \quad 0.59$

$\begin{array}{rr}11.57 & 1.38 \\ 8.74 & 4.78\end{array}$

$\begin{array}{ll}13.22 & 1.37 \\ 15.44 & 3.22\end{array}$

$2.72 \quad 0.78$

$\begin{array}{ll}0.72 & 0.78 \\ 1.54 & 0.33 \\ 0.25 & 0.78\end{array}$

$\begin{array}{rr}10.37 & 1.20 \\ 7.95 & 1.00\end{array}$

$1.50 \quad 0.40$

$\begin{array}{ll}18.04 & 1.35 \\ 17.90 & 1.39\end{array}$

7.90
$15.50 \quad 1.44$

$15.90 \quad 1.67$

$\begin{array}{rr}14.19 & 1.61 \\ 6.66 & 1.29\end{array}$

$\begin{array}{ll}21.28 & 1.99 \\ 10.91 & 1.19\end{array}$

$\begin{array}{rr}14.30 & 1.70 \\ 8.15 & 1.25 \\ 14.34 & 1.29\end{array}$ 
NUTE MPLE NUMEER---D DATE
LONG. L TY RPL HO-DA-YR

PARTIZLE SIZE POS.
UPPER LOHER CONT $\stackrel{0}{x-R E F}$

URANIUMIDNC)
PPM QEAR PPH

$1203332-35.6471-114.6739-1-72-10004 / 14 / 77$ SIREAM $3203432-35.6251-114.6590-1-72-10004114 / 77$ STREAH $1203632-35,6155-114,6593-1-72-10004 / 14 / 77$ STREAH $1203732-35,6222-1 / 4.6470-1-72-10004 / 14 / 77$ STREAH $1203632-35.6177-114.6449-1-72-10004 / 14 / 77$ STREAM 12040 32-35.5889-114.6491-1-72-100 04/14/77 STREAH $1204132-35.5947-114.6677-1-72-10004 / 12177$ STREAH 12042 32-35.5753-114,6881-1-72-100 04/14/77 STREAM 12043 32-35,5380-114,6748-1-72-100 04/14/77 5TREAH (1) 32-35,5184-114,8831-1-72-100 04/14/77 STREAY

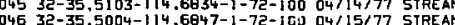
$124632-35,5004-114.6847-1-72-16104 / 15 / 77$ STREAH $120524-35,2462-114,5954-1-72-10004 / 16,5954-1-72-100$ 04/16/77 5TRREAM i2053 4-35,2364-114.5989-1-72-100 04/16/77 STREAM 4-35.2055-114.5866-1-72-100 04/16/77 STREAM 12055 4-35.2118-114.5886-1-72-100 04/16/77 SIREAM 12064 32-35.5527-114.6413-1-72-100 04/17/77 5TREAM $1206532-35.5582-114.6445-1-72-10004 / 17 / 77$ STREAM 作 $1206732-35.5737-114.6540-1-72-10004 / 17 / 77$ STREAM 12131 32-35.6658-115.5154-1-70-100 05/20/77 STREAM 12. 32 6-35-7735-115.9日70-1-70-100 05/20/77 STREAM 133 5-35.7940-115.9609-1-70-100 05/20/77 5IREAM 12135 6-35.7800-115.9964-i-70-100 05/21/77 SIREAM 12162 32-35.9709-115.5405-1-70-100 05/27/77 STREAH 1 2530 6-35.9830-11:-6253-1-70-100 05/20/77 STREAM $12915 \quad 32-35.8961-115,7750-1-72-100$ 05/ $11 / 77$ STREAM I2917 32-35.9117-115.7333-1-72-100 05/11/77 STREAM 19919 3e-35.0B日-115.6240-1-72-100 05/11177 SIREAM 12919 32-35.8056-115.5169-1-72-101 I 2920 32-35.8245-115.5166-1-72-100 05/11/77 STREAH $1292132-35.8131-115.5389-1-72-100$ 05111/777 STREAH I2922 32-35,8536-115.5332-1-72-100 05111/77 STREAM 12923 32-35.8455-115.5229-1-72-100 05111177 STREAM $129432-35.8635-115.5325-1-72-10005 / 11777$ STREAY 1255 32-35.8804-115.5167-1-72-100 O5/2277 STREAY $1292732-35.0908-115.5454-1-72-100$ 05/12/77 STREAM 12028 32-35.0955-115.5684-1-72-100 05/2177 STREAM 作 32-35,8963-115.5595-1-72-101 STREAM -35, 9095-115, 5430-1-72-100 05/12/77 STREAM 32-35.9284-115, 5335-1-72-100 05/12,77 STREAM 12933 32-35, $9373-115,5222-1-72-100$
$05 / 12 / 77$
STREAM

\begin{tabular}{|c|c|c|}
\hline $\begin{array}{l}\text { DRY } \\
\text { SRY }\end{array}$ & 1000 & 0500 \\
\hline DAY & 1000 & $\begin{array}{l}0503 \\
0500\end{array}$ \\
\hline DEY & 1000 & 0500 \\
\hline ORY & 1000 & 0500 \\
\hline DAY & 1000 & 0500 \\
\hline $\begin{array}{l}\text { DRY } \\
\text { DRYY }\end{array}$ & $\begin{array}{l}1000 \\
1000\end{array}$ & $\begin{array}{l}0500 \\
0500\end{array}$ \\
\hline ORY & 1000 & 0500 \\
\hline DRY & 1000 & 0500 \\
\hline UAY & 1000 & 0500 \\
\hline DRY & 1000 & 0500 \\
\hline DRY & 1000 & 0500 \\
\hline DRY & 1000 & 0500 \\
\hline DRY & 1000 & 0500 \\
\hline DRY & 1000 & 0500 \\
\hline DRY & 1000 & 0500 \\
\hline DRY & 1000 & 0500 \\
\hline ORY & 1000 & 0500 \\
\hline DRY & 1000 & 0500 \\
\hline DRY & 1000 & \\
\hline ORY & 100 & 0500 \\
\hline DRY & 1000 & 0500 \\
\hline WET & 1000 & 0500 \\
\hline HET & $\begin{array}{l}1000 \\
1000\end{array}$ & $\begin{array}{l}0500 \\
0500\end{array}$ \\
\hline WET & 1000 & 0500 \\
\hline HET & 1000 & 0500 \\
\hline WE T & 1000 & 0500 \\
\hline $\mathrm{DRY}$ & 1000 & 0500 \\
\hline ORY & 100 & 0500 \\
\hline DRY & 1000 & 0500 \\
\hline DRY & 1000 & 0500 \\
\hline DRY & 1000 & 0500 \\
\hline DRY & 1000 & 0500 \\
\hline DRY & 1000 & 0500 \\
\hline DRY & 1000 & 0500 \\
\hline DRY & 1000 & 0 \\
\hline ORY & 1000 & \\
\hline DRY & 10 & 0500 \\
\hline DRY & 1000 & 0500 \\
\hline DRY & 1000 & 0500 \\
\hline DRY & 100 & 0500 \\
\hline DAY & 10 & Q5 \\
\hline DRY & 100 & 0500 \\
\hline QRY & 100 & \\
\hline DRY & 1000 & 0500 \\
\hline ORY & 1000 & 0500 \\
\hline DRY & 1000 & 0500 \\
\hline
\end{tabular}

\begin{tabular}{|c|c|c|c|}
\hline .33 & 1.64 & 10,44 & 2.13 \\
\hline 2.69 & 1.48 & $10,7 \vec{z}$ & 1.50 \\
\hline 3.91 & $\therefore 48$ & & \\
\hline $\begin{array}{l}3.43 \\
2.97\end{array}$ & 1.24 & & \\
\hline $\begin{array}{l}2.97 \\
3.93\end{array}$ & $\begin{array}{r}50 \\
37\end{array}$ & 19,39 & 1.90 \\
\hline $\begin{array}{l}3.05 \\
\text { 2.89 }\end{array}$ & 41 & 23.16 & 1.69 \\
\hline 1,14 & $\begin{array}{l}.41 \\
1.75\end{array}$ & 16.50 & 1.19 \\
\hline 1.41 & 1.63 & $\begin{array}{l}4.99 \\
6.22\end{array}$ & 0.98 \\
\hline 1.62 & 1.50 & 6.99 & 0.71 \\
\hline 1.43 & i.e8 & 7.56 & 1.64 \\
\hline 1.25 & 1.63 & 7.01 & 0.67 \\
\hline 1.17 & 1.74 & 6.25 & 0.79 \\
\hline 2.93 & 1 .81 & 47.75 & 3.16 \\
\hline 1.43 & 2.41 & 15.23 & 2.59 \\
\hline 4.73 & 1.56 & 53.45 & 4.12 \\
\hline 3.37 & 1.51 & 37,66 & 2.34 \\
\hline 1.59 & 1.60 & 9.39 & 1.03 \\
\hline .23 & 1.65 & 14.98 & 2.03 \\
\hline 43 & 1.57 & 14.27 & 1.68 \\
\hline 3.07 & 1.42 & 20.59 & 1.50 \\
\hline 2.97 & 1,45 & 19.53 & 1.63 \\
\hline 2.36 & 1.48 & 11.75 & 1.54 \\
\hline 1.51 & 1.12 & 6.10 & 1.29 \\
\hline 5.94 & 1.17 & 16.05 & 1.20 \\
\hline 2.09 & 1.54 & & \\
\hline 9,94 & 1,04 & & \\
\hline .04 & i. 97 & 4.54 & 1.34 \\
\hline 1 & 1.47 & 5.59 & 0.90 \\
\hline 1.45 & 1.49 & & \\
\hline 1.80 & 1,50 & 5.16 & 1.20 \\
\hline 1.33 & 1.63 & 1.58 & 0,46 \\
\hline $1.7:$ & 1.40 & 1.73 & 0.50 \\
\hline 1.66 & 1.37 & 1.29 & 0.34 \\
\hline 1.83 & 1.43 & $i, 92$ & 0,56 \\
\hline $\begin{array}{l}1.25 \\
7.70\end{array}$ & 1.50 & & \\
\hline 2.40 & $\begin{array}{l}1.30 \\
1.58\end{array}$ & & \\
\hline .64 & 1.30 & 2.28 & 0.44 \\
\hline 2.49 & 1.30 & & \\
\hline 3.18 & 1.24 & 1.59 & 0.44 \\
\hline & 1.5 & 2.23 & 0,42 \\
\hline 1 & 1,42 & 2.41 & 0.51 \\
\hline .14 & 1,32 & & \\
\hline 46 & $\begin{array}{l}.200 \\
1.29\end{array}$ & & \\
\hline .65 & 1.27 & 1,93 & $0.4 \mathrm{Z}$ \\
\hline & 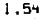 & 2.07 & 0.52 \\
\hline & & & \\
\hline
\end{tabular}


SITE --DOE SAMPLE NUMBER---D DATE SAMPLE PARTICLE SIZE POS
NUMBER ST LAT, LONG, L TY RPL MO-DA-YR SOURCE/CONO, UPPER LOWER CONT a. C.

IRANIUM I DT:C I

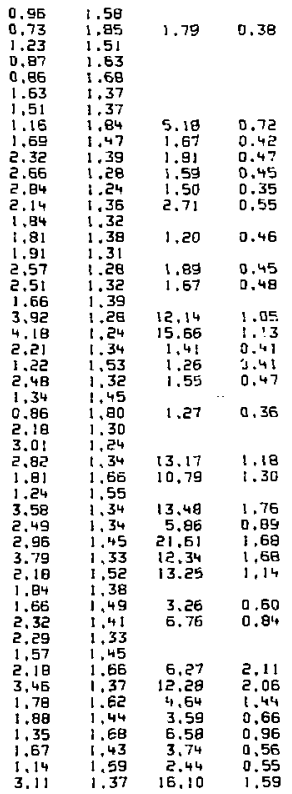

12934 32- $35.9554-115.5319-1-72-10005 / 12 / 77$ STREAM 2935 32-35.9930-115.5123-1-72-100 05/12/77 SIREAM $1293732-35.9726-115.5382-1-72-10005 / 12 / 77$ STREAH

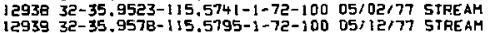
$1293932-35,9578-115.5795-1-72-100$
12939
$32-35,9570-115.5795-1-72-101$ $1294032-35,9858-115,5601-1-72-10005 / 12 / 77$ 5TREAM $1294132-35.9947-115.5722-1-72-100$ 05/12/77 STREAM 12942 3E-35.9163-115.6555-1-72-100 05/12/77 STREAM 12943 32-35.6567-1 15.5725-1-72-100 05/12/77 STREAM $1294432-35.8505-115.5849-1-72-10005 / 12 / 77$ SIREAM

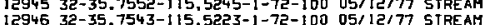
12946
12947
$52-35.7334-115,5003-1-72-100$

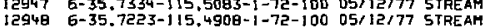
$1294932-35.6572-115.4744-1-72-100$ 05/12/77 STREAM $1294932-35.6572-115.4744-1-72-101$ STREAM $1295032-35,7124-115.4910-1-72-10005 / 13 / 77$ STREAM 12951 32-35.6807-115,4828-1-72-100 05/13/77 STREAM $1295232-35.6779-115.4751-1-72-10005 / 13 / 77$ STREAM $129536-35,6501-115.4867-1-72-10005 / 14 / 77$ STREAM 12954 6-35.6259-115,4971-1-72-100 05/14/77 STREAM 12955 E-35.6312-115.4 12057 6-35.6375-115.5554-1-72-100 05/14/77 STREAM O5r, 1477 STREAM i $29596-65$ 12959 6-35.6307-115.5975-1-72-101 5TREAM $1-72-10005 / 14 / 77$ STREAH 12961 6-35.5927-115.5794-1-7e-100 05/14/77 STREAH $129625-35.6916-115.6373-1-72-10005 / 14 / 77$ STREAM 12963 6-35.6743-115.6232-1-72-100 05/5\%77 STREAM 12955 6-35,7208-115.7400-1 72-100 05 15 77 STREAM 2965 32-35,7719-115.4877-1-72-100 05/15,77 STREAM 12968 32-35.7511-1154956-1-72-100 05/16/77 STREAM 12969 32-35.8195-115,4779-1-72-100 05115/77 STREAM 12969 32-35,8195-115.4779-1-72-101 05 15/7 STREAM $1297032-35.7239-1$ IS,4035-1-72-100 05/15/77 5TREAM 13762 6-35.9395-115.4035-1-72-100 05/15/77 STREAM 13730 6-35.7773 -15.950B-1-72-100 05/01777 STREAM $13093 \quad 5-35,9542-115,9335-$ 13994 5 $13895 \quad 6-3$

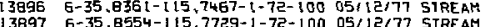

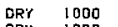

ORY 1000

$\begin{array}{ll}\text { ORY } & 1000 \\ \text { DRY } & 1000\end{array}$

$\begin{array}{ll}\text { ORY } & 1000 \\ \text { ORY } & 1000\end{array}$

ORY $\quad 1000$

DRY

ORY 


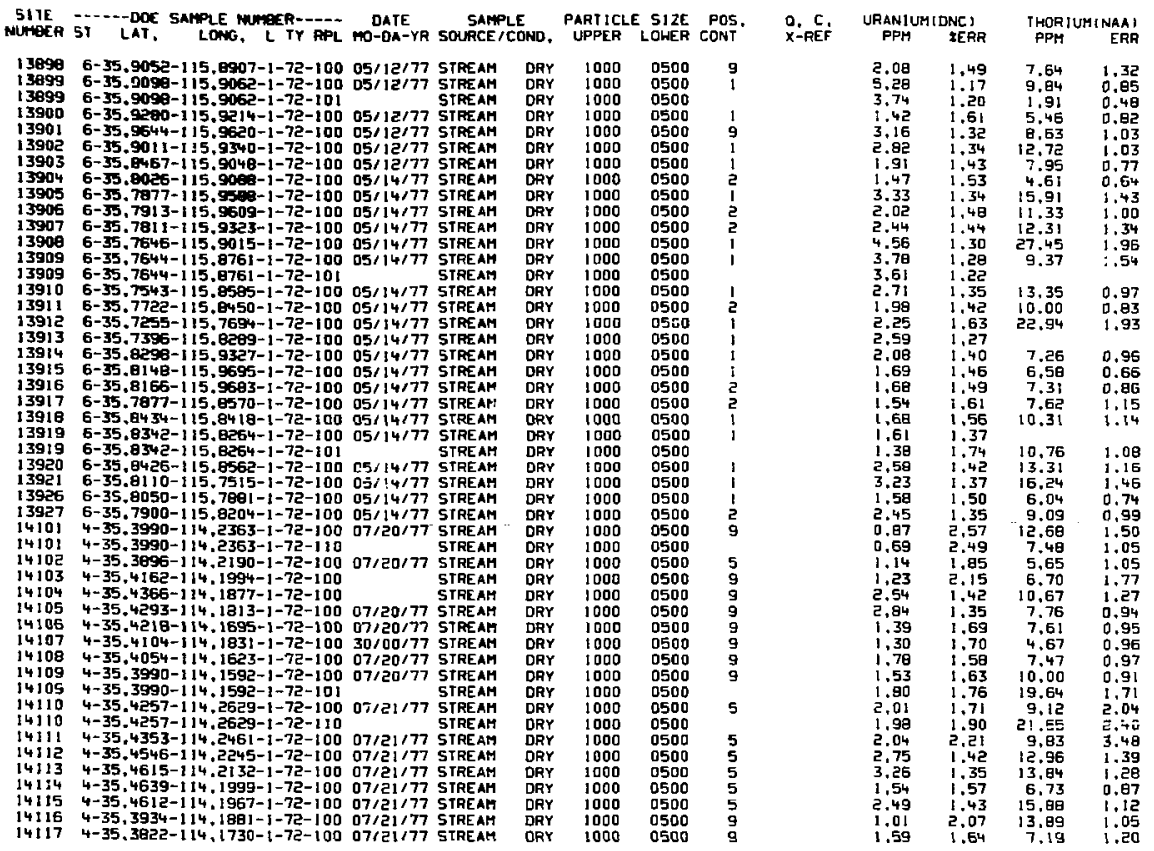




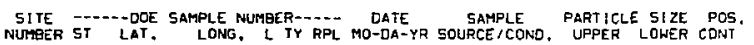

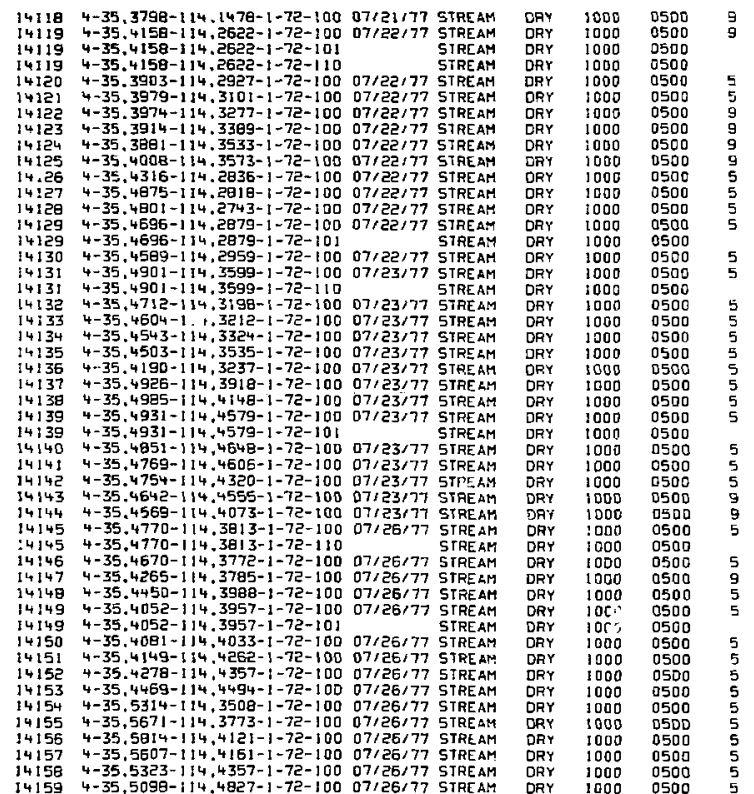
0. C
$X=F$ URANIUM(DNC)
PFH THORIUMINAAT

\begin{tabular}{|c|c|c|c|}
\hline $\begin{array}{l}2.10 \\
1.85\end{array}$ & $: 72$ & 19.19 & $\begin{array}{l}2.03 \\
0.69\end{array}$ \\
\hline 1.93 & 1.39 & & \\
\hline & 1.65 & 0.48 & !. \\
\hline $\begin{array}{l}1,14 \\
3,07\end{array}$ & $\begin{array}{r}2.15 \\
1.47\end{array}$ & 11.76 & $\begin{array}{r}i .52 \\
2.03\end{array}$ \\
\hline & 1.48 & 20.42 & $\begin{array}{l}2.03 \\
1.16\end{array}$ \\
\hline 2,36 & 1.59 & 15,89 & $\therefore .68$ \\
\hline 11 & 1.54 & $\$ 6.06$ & $1 . e^{4}$ \\
\hline 63 & 1.46 & 15.66 & 1.25 \\
\hline .68 & 1.68 & 9.37 & 1.30 \\
\hline I. & 1.65 & 7.97 & 0.93 \\
\hline 1.92 & 1.48 & 5.11 & 0.97 \\
\hline 1.33 & 2.00 & 11,89 & 1.02 \\
\hline 1.31 & $1 . E E$ & 5.80 & 0.85 \\
\hline .34 & 1.68 & 7.22 & $0.7 E$ \\
\hline 36 & 1.76 & 12.54 & 1.07 \\
\hline 1.50 & 1.78 & 8.9 & \\
\hline 1.09 & 1.75 & 5.53 & 0.75 \\
\hline [.5] & I.62 & 9.25 & 0.89 \\
\hline 1.55 & 1.04 & 10.79 & 1.09 \\
\hline $1.6 \bar{~}$ & 1.50 & 7.25 & 0.93 \\
\hline 1.72 & 1,55 & $7.6 \mathrm{~B}$ & 1,10 \\
\hline 2.07 & $\$ .50$ & IZ.OE & 1,20 \\
\hline .94 & 1.87 & 16.4 & ᄅ. $2 \theta$ \\
\hline 1077 & 1.76 & 9.30 & 1.40 \\
\hline 1.51 & 1.93 & 15.57 & 1.93 \\
\hline 1.92 & 1.73 & 13.28 & 1.77 \\
\hline 2.11 & 1.69 & 14,33 & 1,89 \\
\hline 2.54 & 1.62 & 25.09 & 2.15 \\
\hline 2.3 & $1.5 \tilde{3}$ & 16.93 & 1.40 \\
\hline 2.1 & 1.59 & 15.74 & $1 .+9$ \\
\hline 2.4 & 1.48 & 16.32 & 1.39 \\
\hline 2.39 & 1.49 & 10,72 & 1,31 \\
\hline 1.67 & $\because .59$ & 11.43 & 0,94 \\
\hline 9.7 & 1.78 & 13.64 & 1.71 \\
\hline 2,4 & 1.50 & 17.28 & $1.3 !$ \\
\hline 2.69 & 1.54 & 23.21 & \\
\hline$=$ & 1.5 & 20,03 & 2.08 \\
\hline & 1.0 & 16.75 & 2.30 \\
\hline & 1.5 & 13.38 & $1.1 \vec{z}$ \\
\hline 2.5 & 1.59 & 18.74 & 1.80 \\
\hline e. & 1.44 & 15.93 & 1.75 \\
\hline 1.4 & 1.64 & 9,78 & 0,83 \\
\hline 0 & $1.9 \mathrm{E}$ & 7.03 & 0.80 \\
\hline 1.14 & 2.0 & 9,86 & 1.47 \\
\hline 78 & 1.4 & & \\
\hline 2.78 & $\begin{array}{l}1.42 \\
1.53\end{array}$ & $\begin{array}{r}20.23 \\
24.49\end{array}$ & $\begin{array}{l}1.50 \\
2.04\end{array}$ \\
\hline
\end{tabular}




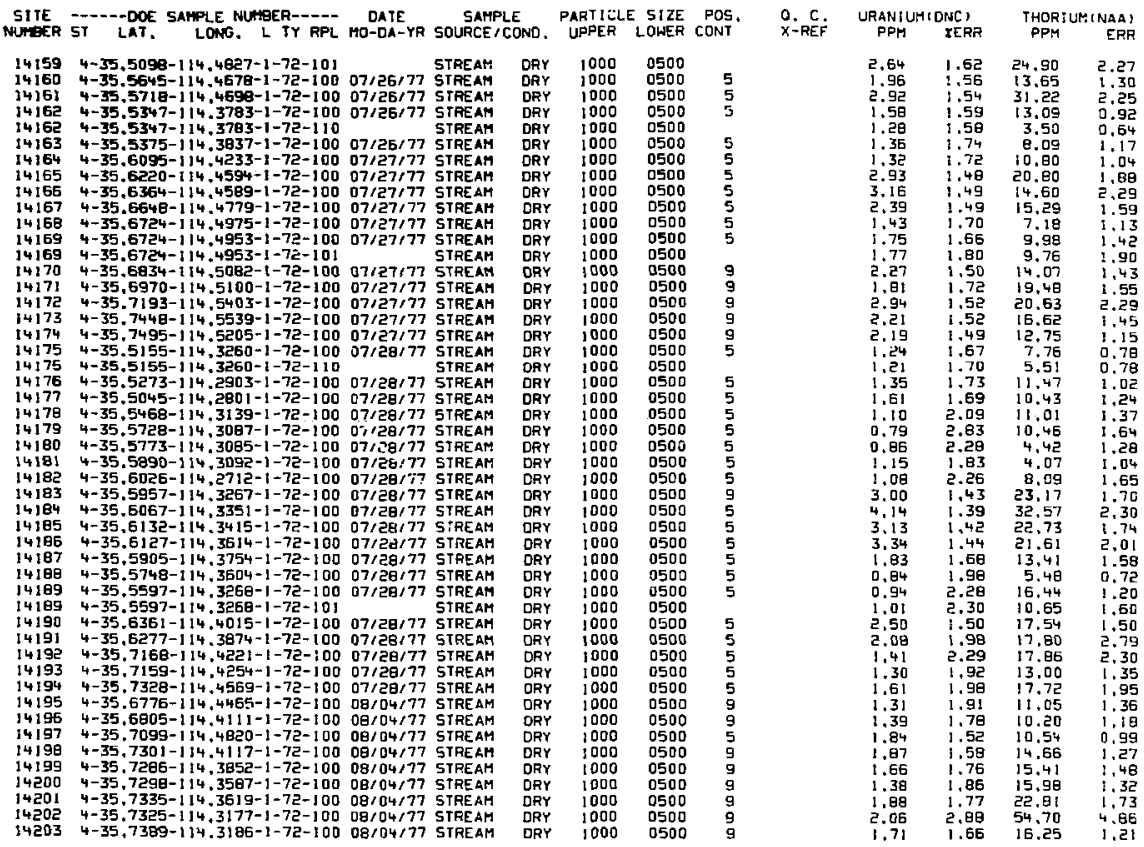




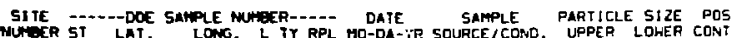
O. $\stackrel{\text { C. }}{x-\text { REF }}$

UPANIUMIDNCS
PPM

$147434-35.1270-114.2466-1-72-100 \quad 07 / 24 / 77$ STREAM

$147444-35.1277-114,3157-1-72-10007 / 24 / 77$ STREAH

$\begin{aligned} & 14745 \\ & 14746\end{aligned} 4-35.0649-114.2487-1-72-10007 / 25 / 77$ STAEAM

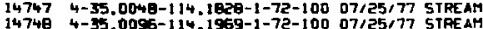

14749 - $-55.0424-114,2111-1-72-10007 / 25 / 77$ STREAM

14749 4-55.0424-114.2111-1-72-10

4-35.0289-114.2116-1-72-100 07/25/77 5TREAM

14751 4-35.0621-114,1689-1-72-100 07/25/77 STREAM

4-35,0633-114,1797-1-72-100 07/25/77 STREAM

14753 4-35.0299-114.2192-1-72-100 07/25/77 5TREAR

14754 - $55.2406-114,3274-1-72-100 \quad 07 / 25 / 77$ STREAM

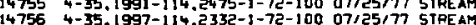

$147574-35.2048-114.1792-1-72-10007 / 25 / 77$ STREAM

14758 4-55.1859-114,1810-j-72-100 07/25/77 STREAM

14759 4-35.1921-114.2148-1-72-100 07/25/77 STREAM

34759 4-55,1921-114,2148-1-72-101

14761 45. 1564-114.2019-1-72-100 07/25/77 STAEAM

14762 4-35.1729-114,1627-1-72-100 07/26/77 STREAM

$\begin{aligned} & 14763 \\ & 14764\end{aligned} 4-35.1656-114.1597-1-72-10007 / 26 / 77$ STREAM

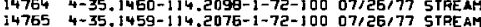

14765 4-35.1155-114.2163-1-72-100 07/26,77 STREAM

14767 4-35.1262-114.1742-1-72-100 07/26/77 5TREAM

\$4768 4-35. \$458-114.1242-1-72-100 07/26/77 5TREAM

$147694-35.1302-114.1116-1-72-10007 / 25 / 77$ SIREAM

$147694-35 \cdot 1302-114.1116-1-72-10107109$ STREAM

$147704-35.1594-114.0875-1-72-100 \quad 07 / 26 / 77$ 5TREAM

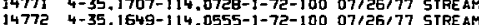

$\begin{aligned} & 14772 \\ & 147735\end{aligned} 4-35.1649-114.0555-1-72-10007 / 26 / 77$ STREAM

14774 4-35.1534-114.0636-1-72-100 07/26,77 STREAM

14775 4-35.1814-114.0329-1-72-100 07/26/77 5TREAM

14777 4-35.2549-114.3214-1-72-1C0 07/26/77 5TREAM

14778 4-35.2731-114.2978-1-72-100 07/26/77 5TREAM

14799 4-35,3011-114.2935-1-72-100 07/26/77 5TREAM

4479 4-35.3011-114.2935-1-72-101

14780 $4-35,3065-114,3340-1-72-10007 / 26 / 77$ STFEAM

i4782 $4-35.3057-114.3373-1-72-10007 / 26 / 77$ STREAM

14783 4-35.2515-114.2919-1-72-100 07/26/77 5IREAM

$94 \quad 4-35.2362-114,0243-1-72-10007 / 27 / 77$ 5TREAM

14785 4-35.2065-114,0649-1-72-100 07/27/77 STREAM

14766 - $-35.1967-1 / 4.0762-1-72-10007 / 27 / 77$ STREAM

14788 4-35.3304-114.2186-1-72-100 07/27/77 5IREAM

$\begin{array}{llll}\text { DRY } & 1000 & 0500 & 5 \\ \text { DRY } & 1000 & 0500 & 5 \\ \text { DRY } & 1000 & 0500 & 5 \\ \text { DRY } & 1000 & 0500 & 5 \\ \text { DRY } & 1000 & 0500 & 5 \\ \text { DRY } & 1000 & 0500 & 5 \\ \text { DRY } & 1000 & 0500 & 5 \\ \text { ORY } & 1000 & 0500 & 5 \\ \text { DRY } & 1000 & 0500 & 5 \\ \text { DRY } & 1000 & 0500 & 5 \\ \text { ORY } & 1000 & 0500 & 5 \\ \text { DRY } & 1000 & 0500 & 5 \\ \text { DRY } & 1000 & 0500 & 5 \\ \text { ORY } & 1000 & 0500 & 5 \\ \text { DRY } & 1000 & 0500 & 5 \\ \text { DRY } & 1000 & 0500 & 5 \\ \text { DRY } & 1000 & 0500 & 5 \\ \text { ORY } & 1000 & 0500 & 5 \\ \text { ORY } & 1000 & 0500 & 5 \\ \text { DRY } & 1000 & 0500 & 5 \\ \text { DRY } & 1000 & 0500 & 5 \\ \text { DRY } & 1000 & 0500 & 5 \\ \text { DRY } & 1000 & 0500 & 5 \\ \text { ORY } & 1000 & 0500 & 5 \\ \text { DRY } & 1000 & 0500 & 5 \\ \text { DRY } & 1000 & 0500 & 5 \\ \text { DRY } & 1000 & 0500 & 5 \\ \text { DRY } & 1000 & 0500 & 5 \\ \text { DRY } & 1000 & 0500 & 5 \\ \text { DRY } & 1000 & 0500 & \\ \text { DRY } & 1000 & 0500 & 5 \\ \text { ORY } & 1000 & 0500 & 5 \\ \text { DRY } & 1000 & 0500 & 5 \\ \text { DRY } & 1000 & 0500 & 5 \\ \text { DRY } & 1000 & 0500 & 1 \\ \text { ORY } & 1000 & 0500 & 5 \\ \text { DRY } & 1000 & 0500 & 5 \\ \text { DRY } & 1000 & 0500 & 1 \\ \text { DRY } & 1000 & 0500 & 1 \\ \text { DRY } & 1000 & 0500 & \\ \text { DRY } & 1000 & 0500 & 1 \\ \text { DRY } & 1000 & 0500 & 1 \\ \text { DRY } & 1000 & 0500 & 5 \\ \text { DRY } & 1000 & 0500 & 5 \\ \text { ORY } & 1000 & 0500 & 9 \\ \text { DRY } & 1000 & 0500 & 9 \\ \text { DRY } & 1000 & 0500 & 5 \\ \text { DRY } & 1000 & 0500 & 5 \\ \text { DRY } & 1000 & 0500 & 5 \\ & & & \end{array}$

$21.40 \quad 2.11$

$\begin{array}{ll}23.57 & 1.59 \\ 19.06 & 1.57\end{array}$

$\begin{array}{ll}3.05 & 1.32 \\ 11.47 & 1.15\end{array}$

$10.2 \mathrm{i} \quad 1.53$

$15.8 \mathrm{i} 1.82$

35. 5.65

$28.32 \quad 1.98$

$10.69 \quad 2.67$

$10.58 \quad 1.50$

9.56

$5.59 \quad 1.28$

11.60

9.22

10.59

0.50

1..93

B. 23

13.90

20.00

9.39

13.98

5.31

10.51

i6. 05

14,01
19.32

12.26

18,94

16.99

2.85

5.65

0.93
$? .53$ 


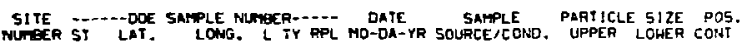
Q. $C$. PEF

\begin{tabular}{|c|c|c|}
\hline $\begin{array}{l}\text { DRY } \\
\text { DFY }\end{array}$ & $\begin{array}{l}1000 \\
1000\end{array}$ & $\begin{array}{l}0500 \\
0500\end{array}$ \\
\hline & 1000 & 0500 \\
\hline $\begin{array}{l}\text { DRY } \\
\text { DRY }\end{array}$ & $\begin{array}{l}1000 \\
1000\end{array}$ & $\begin{array}{l}0500 \\
0500\end{array}$ \\
\hline HET & 3000 & 0500 \\
\hline $\begin{array}{l}\text { ORY } \\
\text { DAY }\end{array}$ & $\begin{array}{l}1000 \\
1000\end{array}$ & $\begin{array}{l}0500 \\
0500\end{array}$ \\
\hline DRY & 1000 & 0500 \\
\hline DRY & 1000 & 0500 \\
\hline DRY & 1000 & 0500 \\
\hline $\begin{array}{l}\text { DRY } \\
\text { ORY }\end{array}$ & 1000 & 0500 \\
\hline ORY & 1000 & 0500 \\
\hline DRY & 1000 & 0500 \\
\hline DRY & 1000 & 0500 \\
\hline ORY & 1000 & 0500 \\
\hline DRY & 1000 & 0500 \\
\hline DRY & 1000 & 0500 \\
\hline DRY & 1000 & 0500 \\
\hline $\begin{array}{l}\text { DRY } \\
\text { ORY }\end{array}$ & 1000 & 0500 \\
\hline $\begin{array}{l}\text { DRT } \\
\text { ORY }\end{array}$ & $\begin{array}{l}1000 \\
1000\end{array}$ & $\begin{array}{l}0500 \\
0500\end{array}$ \\
\hline DRY & 1000 & 0500 \\
\hline ORY & 1000 & 0500 \\
\hline & 1000 & 0500 \\
\hline & 100 & 0500 \\
\hline DRY & 1000 & 0500 \\
\hline DRY & 1000 & 0500 \\
\hline$\overline{D R Y}$ & 1000 & 0500 \\
\hline DRY & 1000 & 0500 \\
\hline DRY & 1000 & 0500 \\
\hline DRY & 1000 & 0500 \\
\hline DRY & 1000 & 0500 \\
\hline DRY & 1000 & 0500 \\
\hline GRY & 1000 & 0500 \\
\hline DRY & ioug & 0500 \\
\hline ORY & 1000 & 0500 \\
\hline DRY & 1000 & 0500 \\
\hline DRY & 1000 & 0500 \\
\hline DRY & 1000 & 0 \\
\hline DRY & 1000 & 0500 \\
\hline DRY & 1000 & 0500 \\
\hline DRY & 1000 & a500 \\
\hline DRY & 1000 & 0500 \\
\hline & & 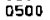 \\
\hline WE & 10 & \\
\hline HET & 1000 & 0500 \\
\hline DRY & 1000 & 0500 \\
\hline
\end{tabular}

\begin{tabular}{|c|c|c|c|c|}
\hline \multirow[t]{38}{*}{$\vec{x}-P \vec{E} \dot{F}$} & PFM & 2EPR & $P P M$ & $\underline{E P R}$ \\
\hline & $\begin{array}{l}1.41 \\
2.03 \\
1.29\end{array}$ & $\begin{array}{l}1.83 \\
1.99 \\
1.43\end{array}$ & $\begin{array}{l}19.33 \\
16.53\end{array}$ & $\begin{array}{l}1.37 \\
2.89\end{array}$ \\
\hline & $1-34$ & 1.59 & $3.5 \mathrm{~B}$ & 1.15 \\
\hline & $\begin{array}{l}1.2 ! \\
2.34\end{array}$ & $\begin{array}{l}1.73 \\
1.49\end{array}$ & $\begin{array}{r}3.7 \mathrm{R} \\
20.43\end{array}$ & $\begin{array}{l}1.06 \\
1.29\end{array}$ \\
\hline & $\begin{array}{l}2 .+1 \\
1.26\end{array}$ & $\begin{array}{l}1.52 \\
1.74\end{array}$ & $\begin{array}{r}21 .: 5 \\
7.78\end{array}$ & $\begin{array}{l}.53 \\
1.53\end{array}$ \\
\hline & 1.01 & 1.76 & 9.62 & $\begin{array}{l}1.08 \\
0.09\end{array}$ \\
\hline & 1.21 & $\begin{array}{l}2.02 \\
1.90\end{array}$ & $\begin{array}{r}8.27 \\
20.31\end{array}$ & 1.56 \\
\hline & $\begin{array}{l}1.53 \\
1.30 \\
1.55\end{array}$ & $\begin{array}{l}1.59 \\
:-79\end{array}$ & $\begin{array}{r}20.31 \\
7.29\end{array}$ & $\begin{array}{l}1.58 \\
0.99\end{array}$ \\
\hline & $\begin{array}{l}1.55 \\
2.33\end{array}$ & $\begin{array}{l}1.44 \\
1.71\end{array}$ & 30,24 & : .૬a \\
\hline & 1.76 & 1.53 & 10.35 & $\begin{array}{r}90 \\
: .03\end{array}$ \\
\hline & $3.4 \overline{7}$ & 1.32 & 13.13 & 1.15 \\
\hline & 2.77 & 1.43 & 15.47 & 1.62 \\
\hline & 1.79 & 1.51 & 5.84 & 1.13 \\
\hline & $\begin{array}{l}1.68 \\
1.53\end{array}$ & $\begin{array}{l}1.5 E \\
1.3 E\end{array}$ & $7.3 !$ & \\
\hline & 1.09 & 1.61 & 4.97 & 0.97 \\
\hline & 1.30 & 2.08 & 12.30 & 3.80 \\
\hline & 1.22 & $\begin{array}{r}2.20 \\
1.85\end{array}$ & 17.64 & $\begin{array}{l}1.74 \\
0.84\end{array}$ \\
\hline & 1.00 & $\begin{array}{l}1.85 \\
1.63\end{array}$ & $\begin{array}{r}5.65 \\
11.16\end{array}$ & 1.53 \\
\hline & 1.12 & 2,16 & 13,19 & 1.56 \\
\hline & 1.17 & :5! & 7.72 & 1,32 \\
\hline & $\begin{array}{l}1.37 \\
3.37\end{array}$ & $\begin{array}{l}1.86 \\
1.25\end{array}$ & $\begin{array}{l}8.23 \\
7.84\end{array}$ & 7.41 \\
\hline & 1.45 & 1. & $\begin{array}{r}1.84 \\
4.87\end{array}$ & 1.63 \\
\hline & 1,51 & 1.39 & & \\
\hline & 1.34 & 2.09 & 14.98 & 1,94 \\
\hline & $\therefore$. & 1,99 & 13.92 & $i .77$ \\
\hline & $\therefore .73$ & 1.73 & 10.08 & 1.75 \\
\hline & 1.94 & 1.58 & 13.09 & $\begin{array}{l}1.52 \\
1.27\end{array}$ \\
\hline & $\begin{array}{l}1.54 \\
1.00\end{array}$ & $\begin{array}{l}1.66 \\
1.82\end{array}$ & $\begin{array}{l}5.37 \\
7.84\end{array}$ & 0.74 \\
\hline & 1.16 & 2,27 & 5.46 & 1.87 \\
\hline & 1.10 & 2.64 & 6.90 & 5.29 \\
\hline & 1.34 & 1.61 & B.-24 & 1.29 \\
\hline & 1.00 & $\begin{array}{l}2,25 \\
3.15\end{array}$ & $\begin{array}{r}5.81 \\
11.58\end{array}$ & $\begin{array}{l}1.50 \\
6.56\end{array}$ \\
\hline & $\begin{array}{l}2.32 \\
1.62\end{array}$ & 1.71 & $\begin{array}{l}11.58 \\
10.82\end{array}$ & 1.34 \\
\hline & 1.63 & $\therefore .60$ & 10.17 & 1,41 \\
\hline & 2.31 & 1.75 & 15.54 & 2.50 \\
\hline & 1.77 & 1.56 & 11.63 & 0.94 \\
\hline & $\begin{array}{l}1.92 \\
2.69\end{array}$ & $\begin{array}{l}1.52 \\
1.94\end{array}$ & $\begin{array}{r}8.61 \\
15.06\end{array}$ & $\begin{array}{l}1.12 \\
3.01\end{array}$ \\
\hline & 2.07 & 1.59 & 12.34 & 14 \\
\hline
\end{tabular}




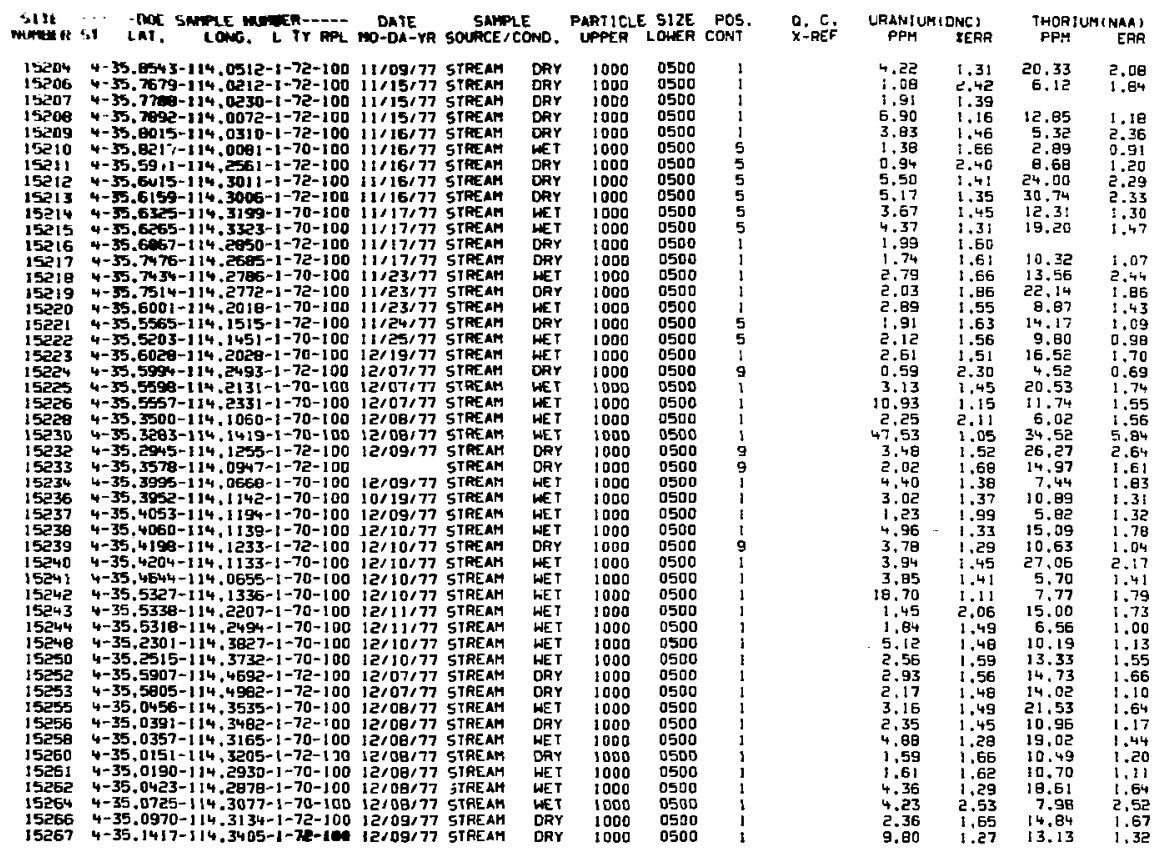




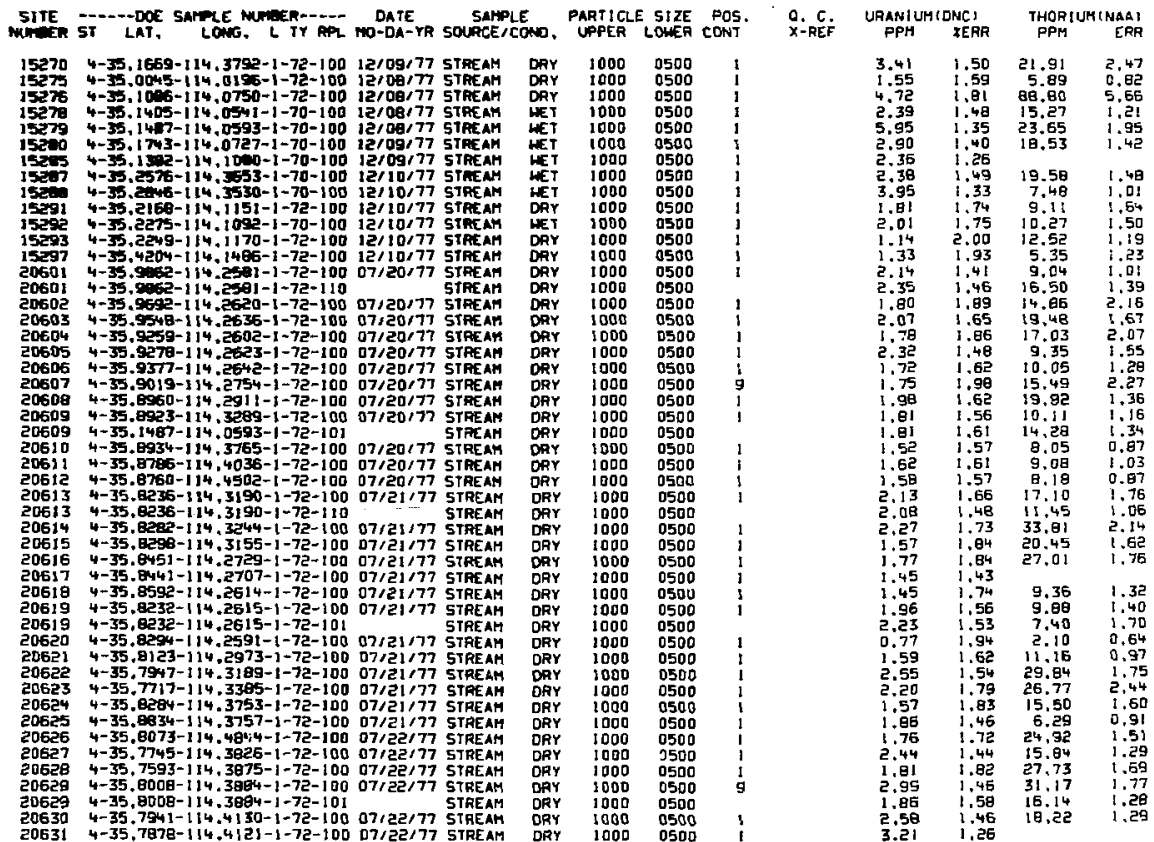




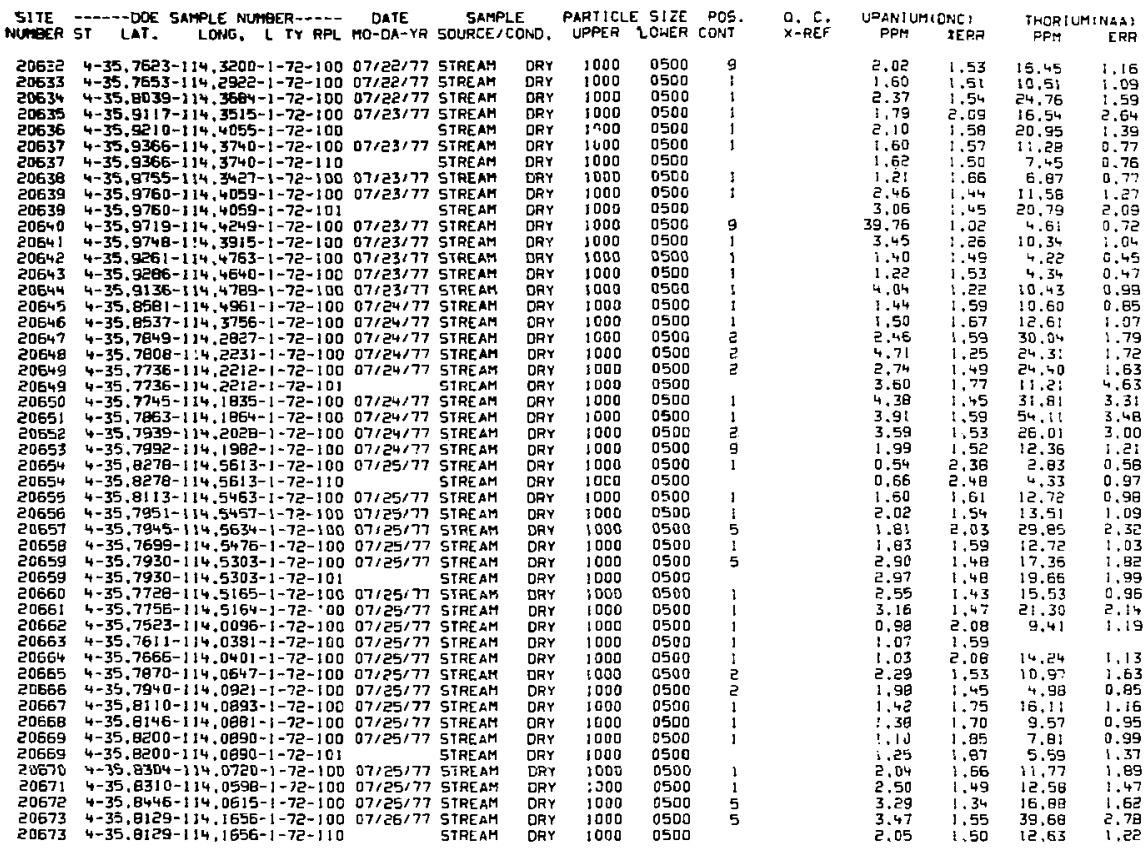




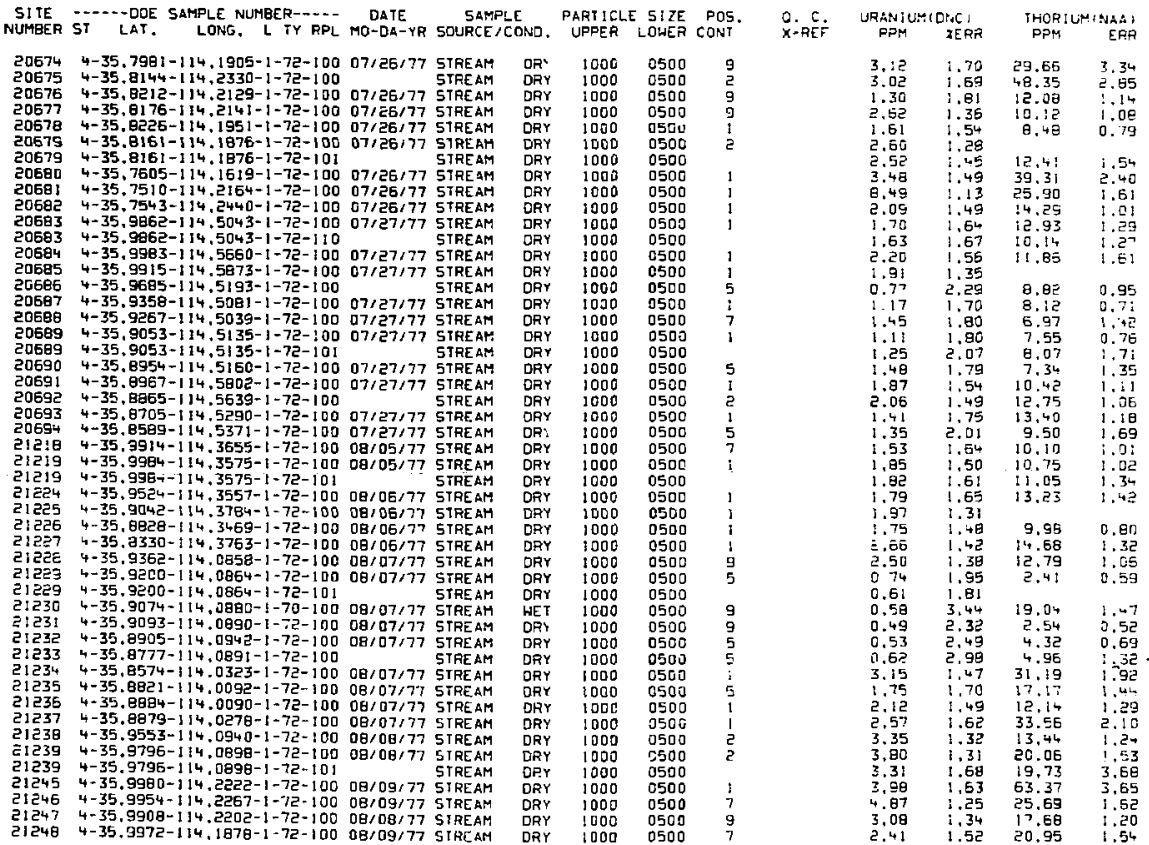




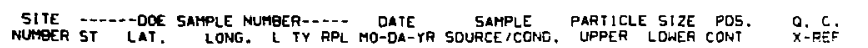

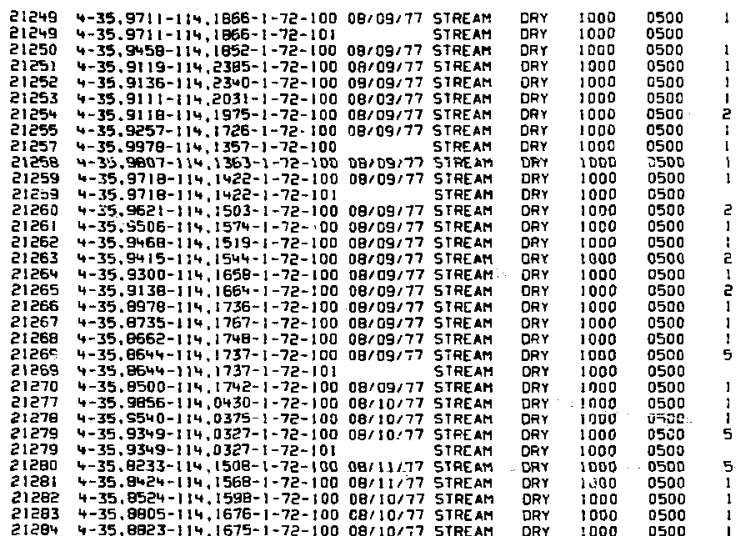

URANTUMIONCJ

THORIUMTNAAF
PPY ER ERR

$\begin{array}{ll}3.65 & 1.29 \\ 3.15 & 1.42 \\ 2.51 & 1.45 \\ 2.54 & 2.30 \\ 3.01 & 1.50 \\ 1.72 & 1.63 \\ 1.69 & 1.72 \\ 2.04 & 1.46 \\ 1.30 & 1.69 \\ 2.14 & 1.54 \\ 0.78 & 1.94 \\ 0.68 & 2.16 \\ 0.76 & 2.62 \\ 1.97 & 1.51 \\ 0.95 & 2.05 \\ 1.28 & 1.60 \\ 1.54 & 1.60 \\ 0.67 & 2.09 \\ 1.29 & 1.51 \\ 1.21 & 1.79 \\ 1.26 & 1.85 \\ 1.31 & 1.53 \\ 1.71 & 1.60 \\ 1.44 & 1.56 \\ 2.77 & 1.24 \\ 1.85 & 1.45 \\ 2.39 & 1.42 \\ 2.25 & 1.39 \\ 3.63 & 1.28 \\ 1.62 & 1.57 \\ 1.46 & 1.58 \\ 0.72 & 1.70 \\ 0.42 & 2.48\end{array}$

$16.63 \quad i .20$

$14.19 \quad 1.45$

$71.84 \quad 4.24$

$13.12 \quad 1.17$

$13.91 \quad 1.58$

0.91
6.69

$6.69 \quad 0.00$

9.79
2.80

$5.55 \quad 1.21$

$9.27 \quad 1.15$

$\begin{array}{ll}7.83 & 1.07 \\ 6.02 & 0.69\end{array}$

$9.16 \quad 0.99$

$2.61 \quad 0.58$

$13.44 \quad 1.13$

15.21

$6.35 \quad 0.74$

$8.78 \quad 0.89$

i0. 1401.08

$15.05 \quad 1.37$

$10.72 \quad 0.89$

$2.43 \quad 0.49$ 


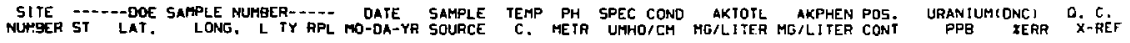

7378 6-35.1120-114.9964-1-22-200 03/14/77 STREAM $19,0 \quad 7.9$

485. 220.

$3.65 \quad 2.05$ 


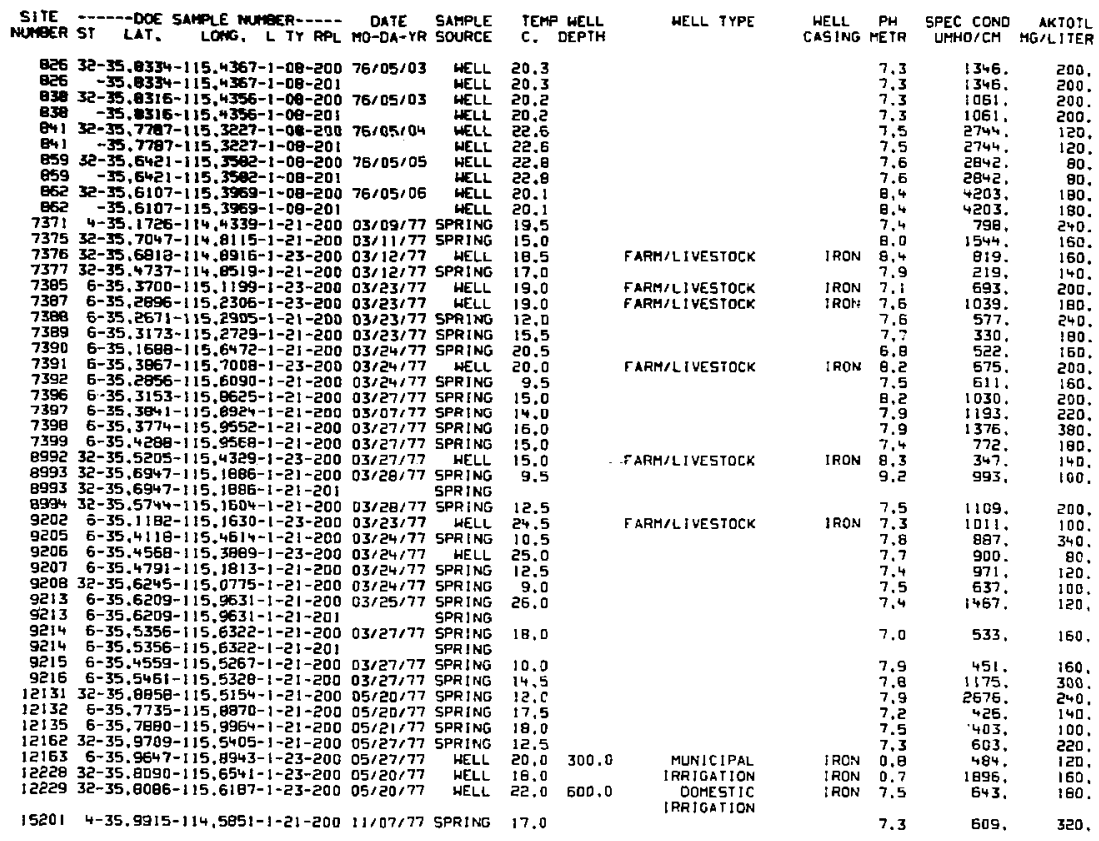




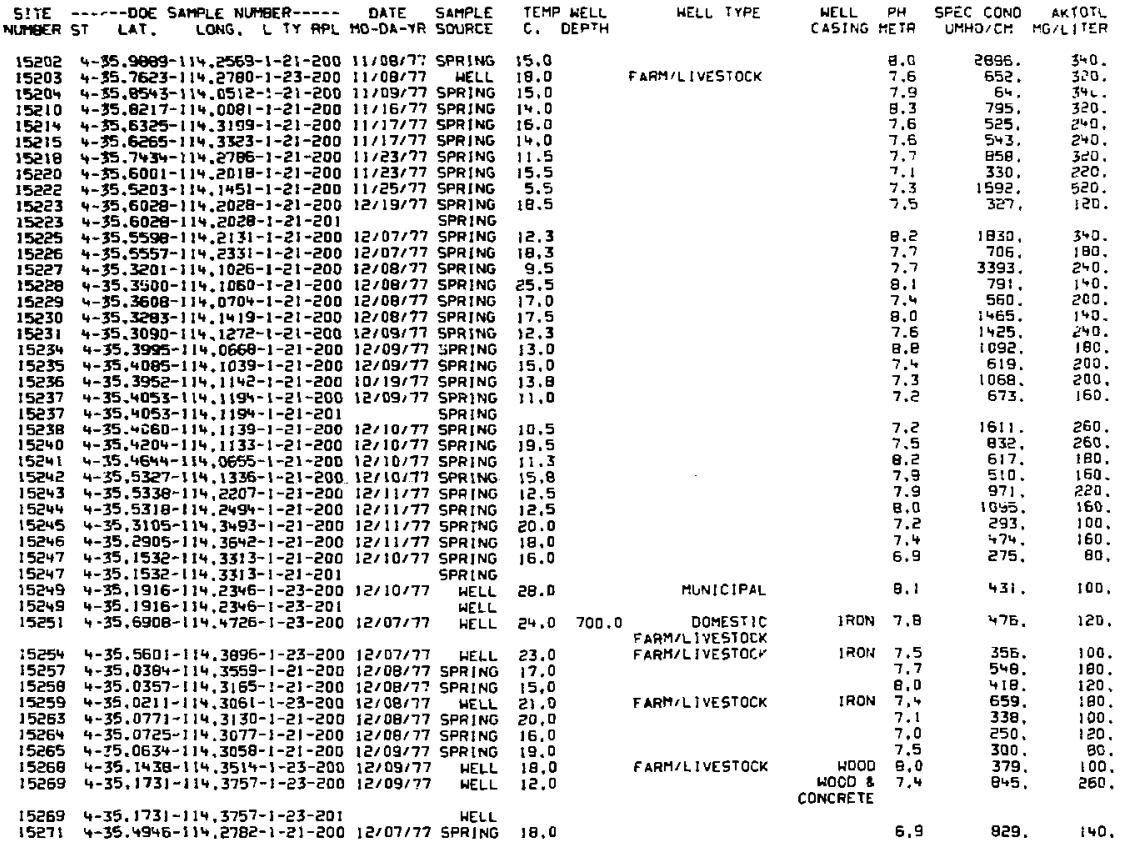




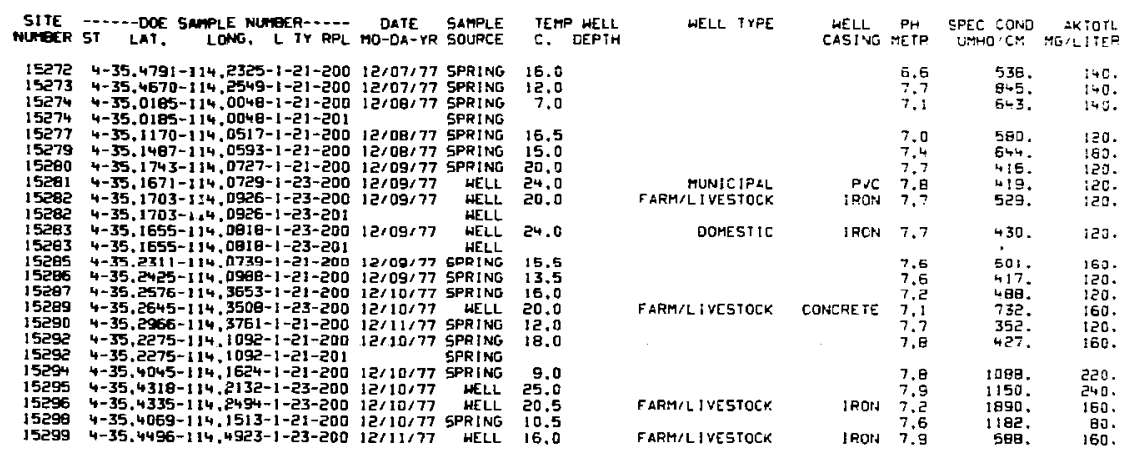


$\underset{\text { SITE APL TPTR AKPHEN POS. URANIUHIJNCI }}{\text { Q. C. }}$

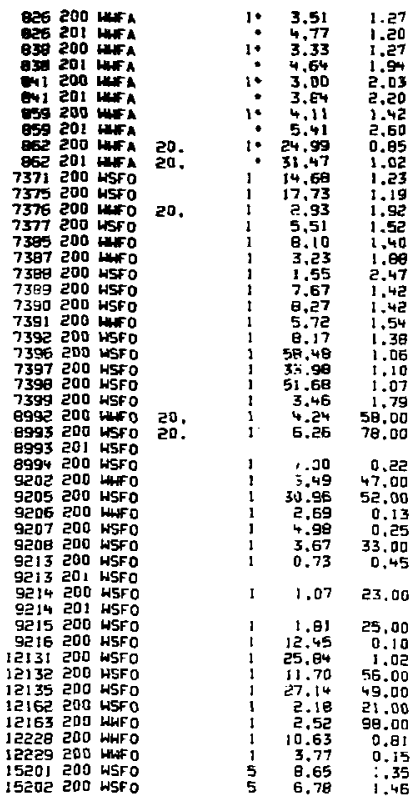




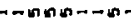

鼓

i

i

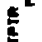

0000000000000000000000000000000000000000000000000

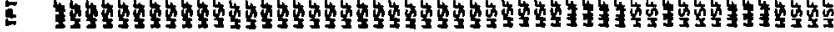

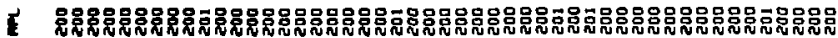




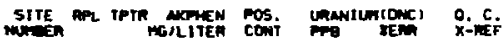

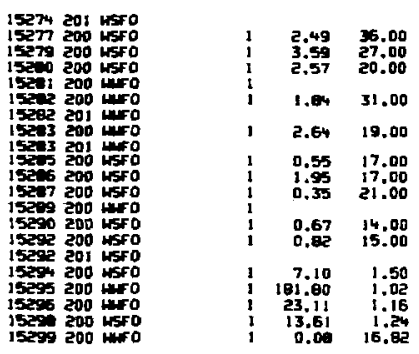




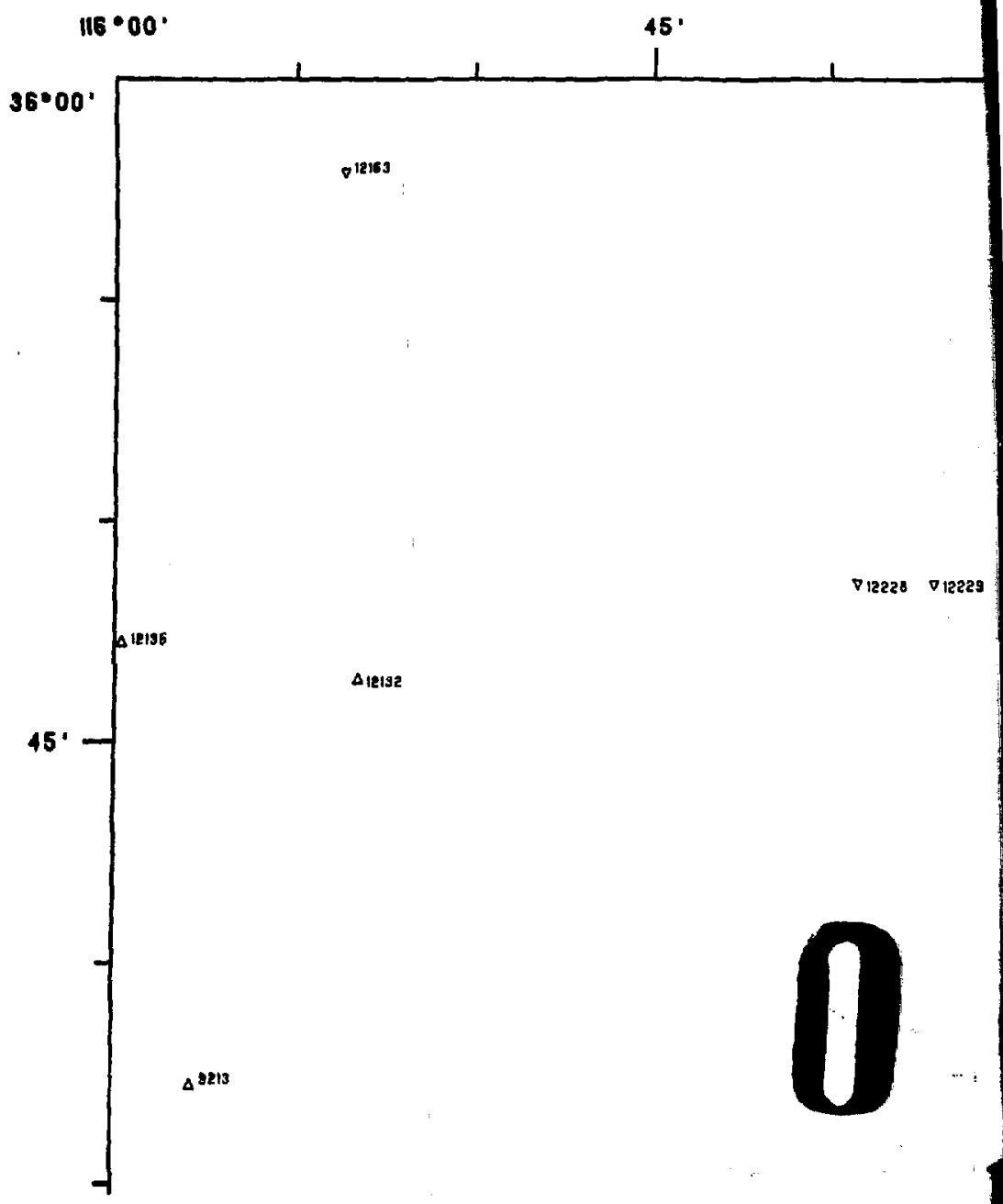




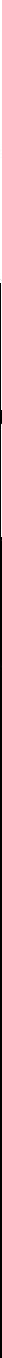


NI 11-03

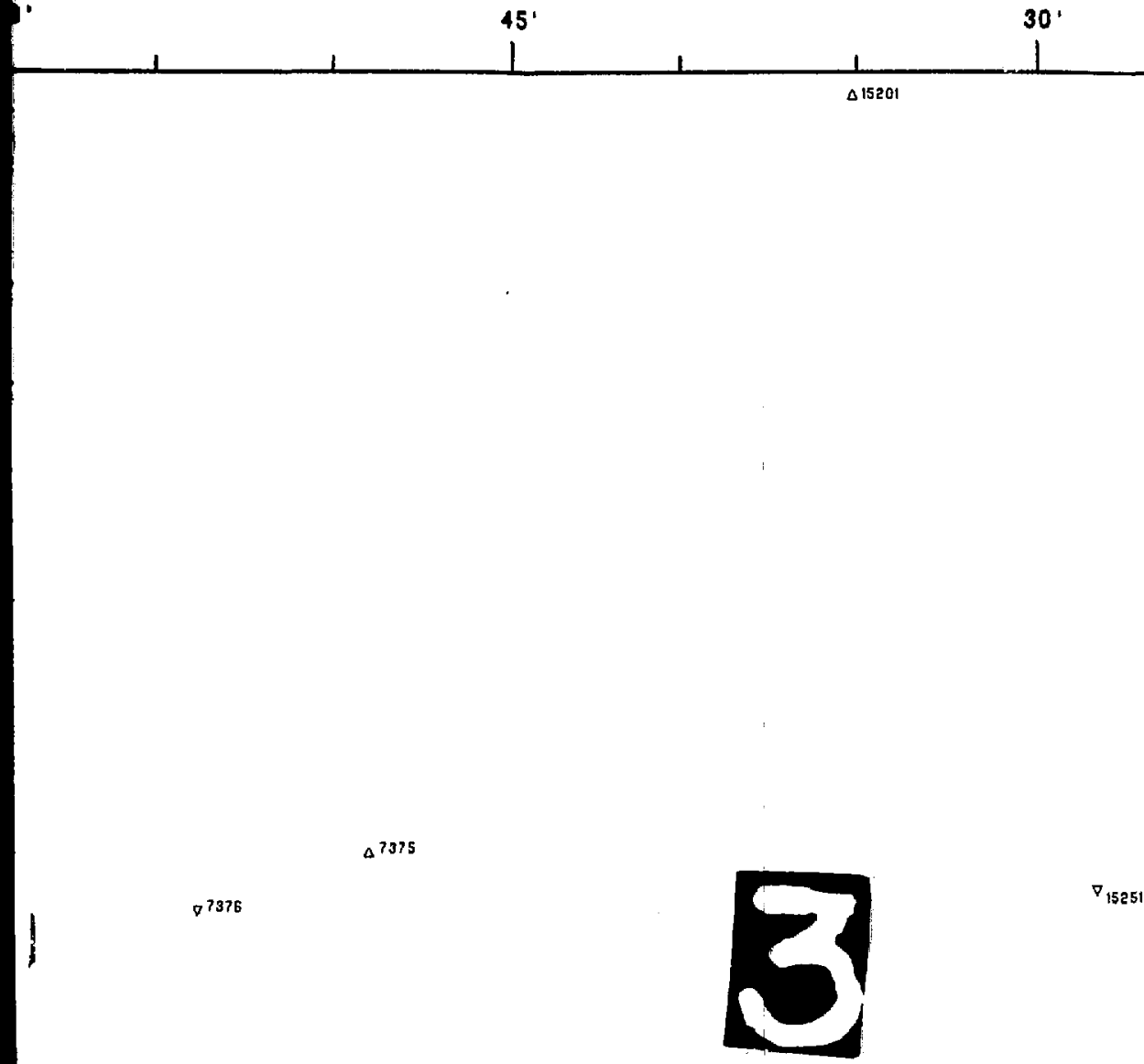




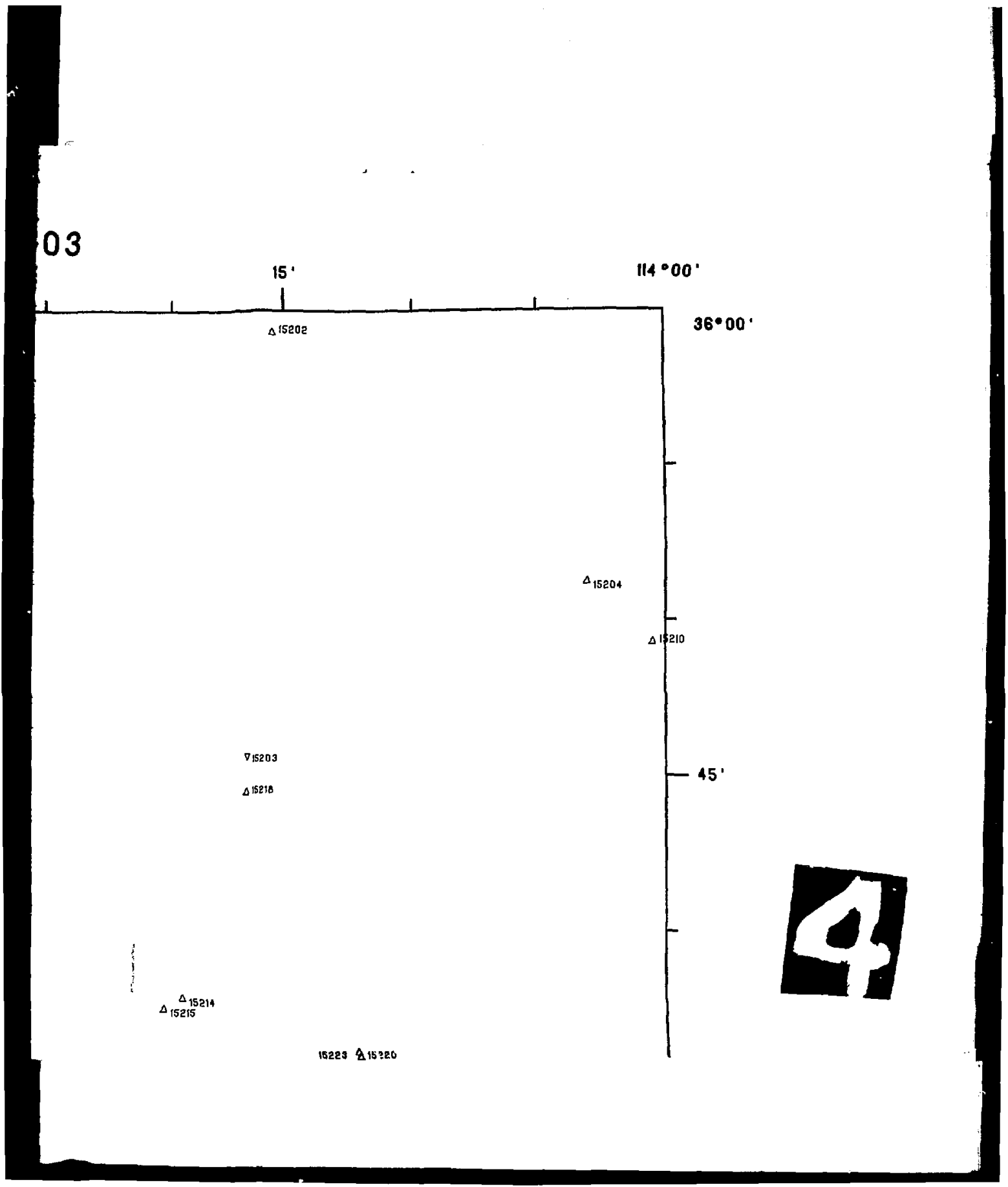




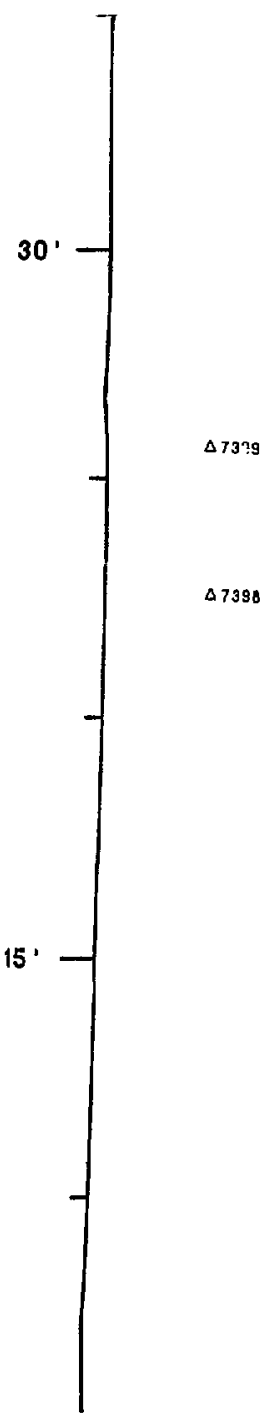

$\Delta$ gai4

Q7397

$\nabla_{7391}$

$\triangle 7396$

$\Delta^{7392}$

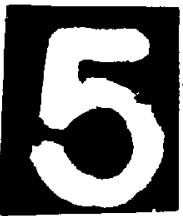

$\Delta 7390$ 
$\triangle 9216$

$$
\nabla^{8992}
$$

$$
\Delta \text { eens }
$$

$\triangle 7389$

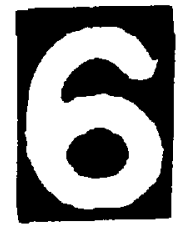




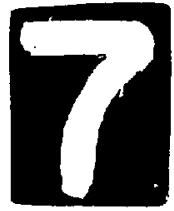

$\Delta 7371$

$\nabla 15269$ $\Delta 15290$

$\nabla 1$ $\triangle 15207$

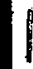


$\sim 15254$

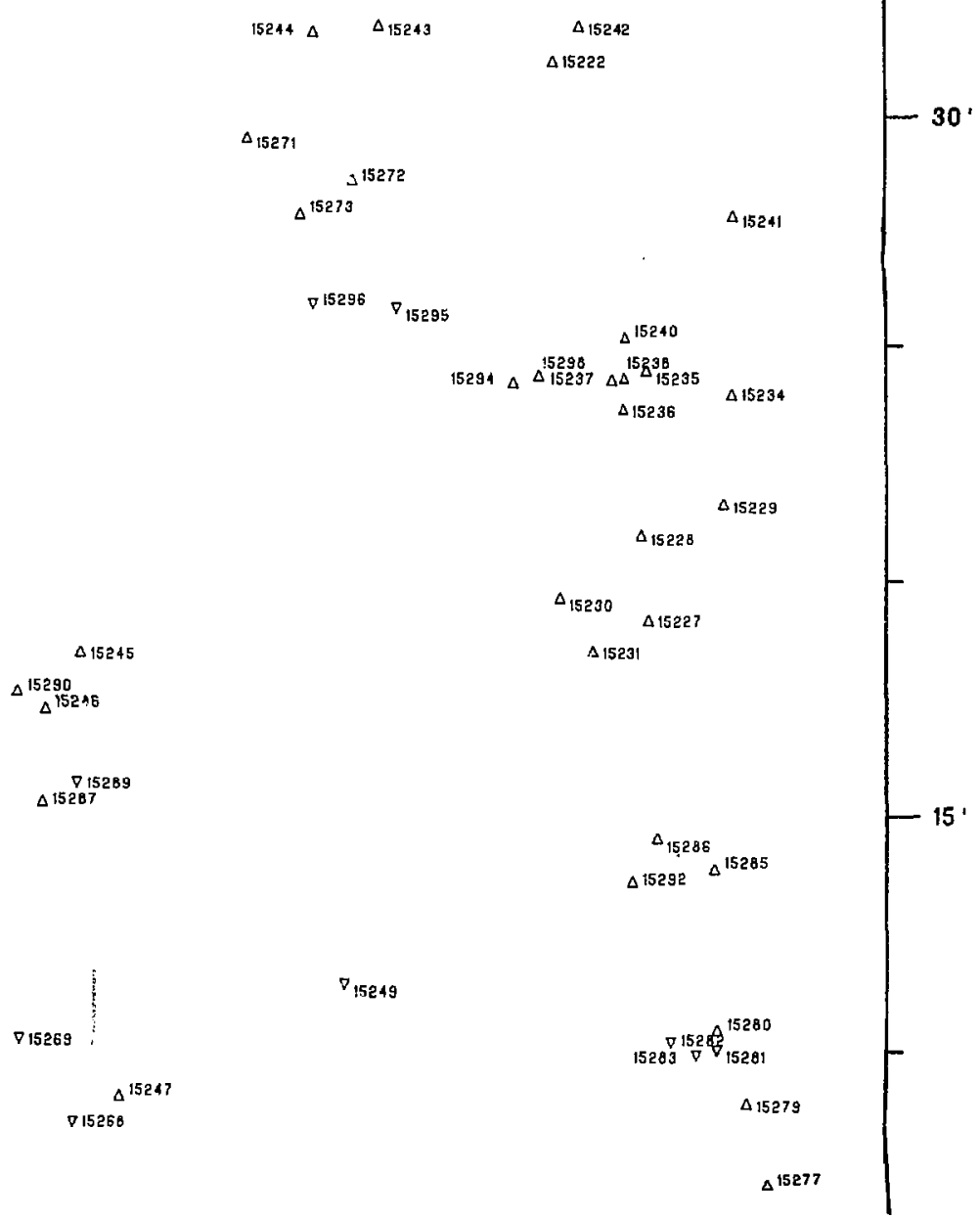




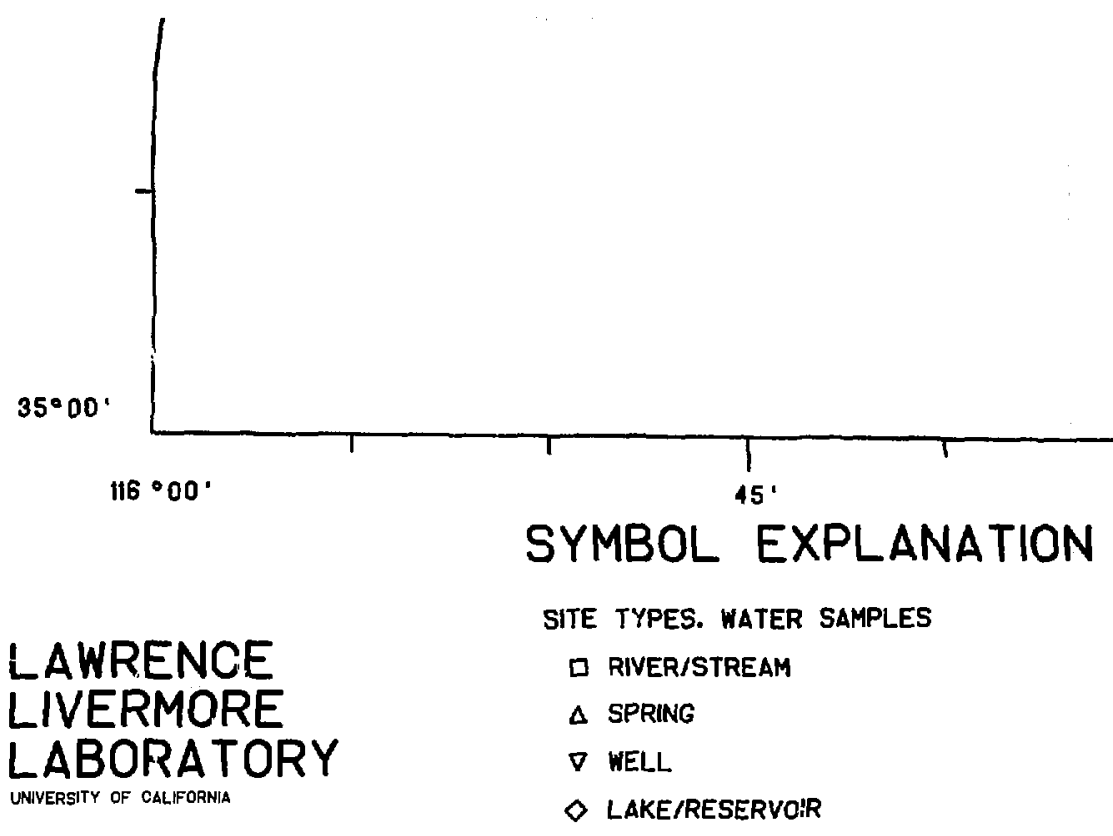

SER NO. LLL, NURE:HSSR 12,45,02 U 07/26/76

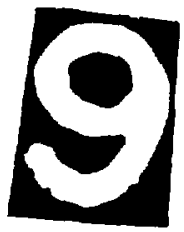




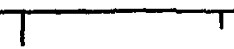

$30^{\circ}$ $115^{\circ} 00^{\circ}$

SCALE 1,25000

5

SITE LOCATIONS. WAT 


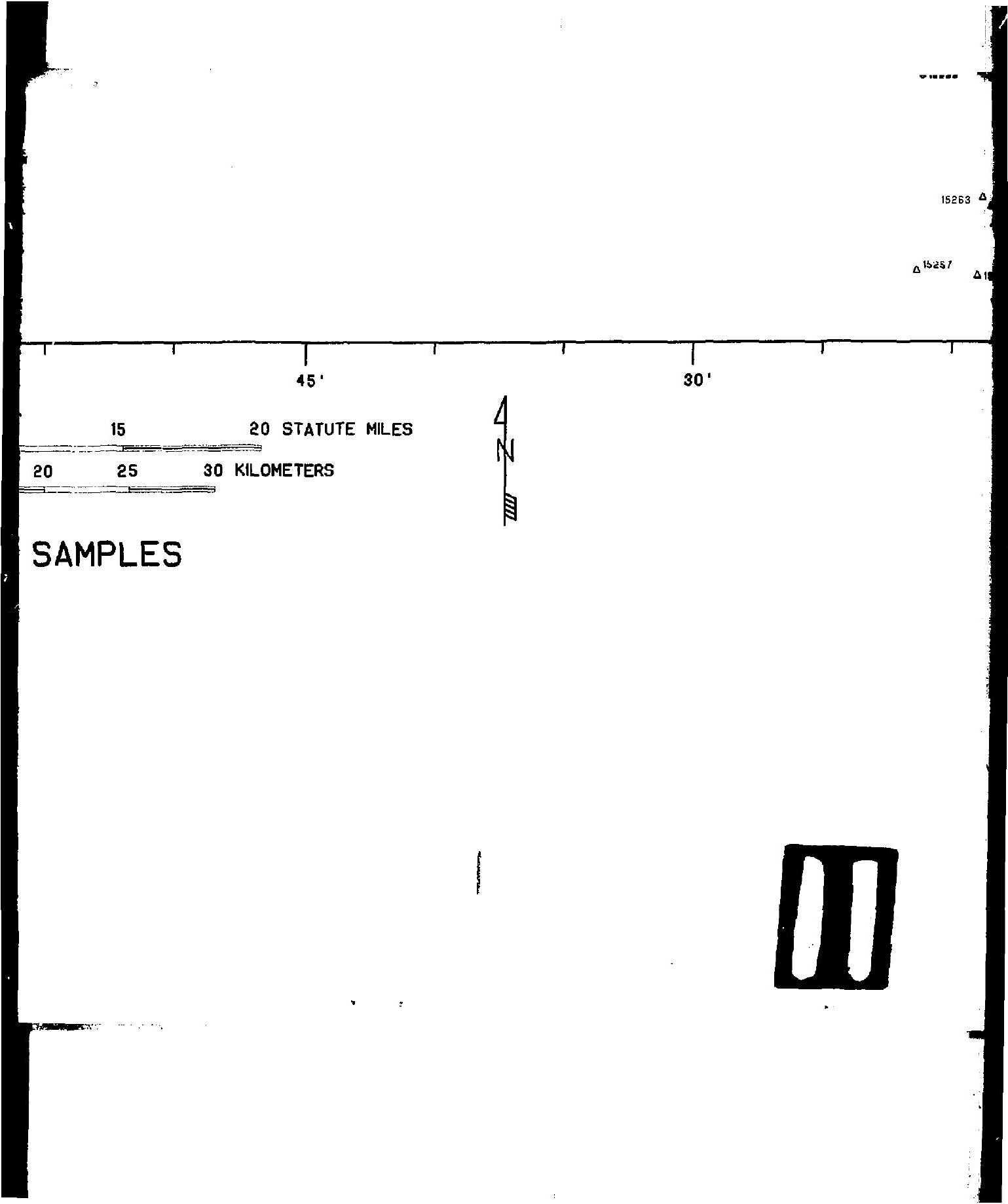




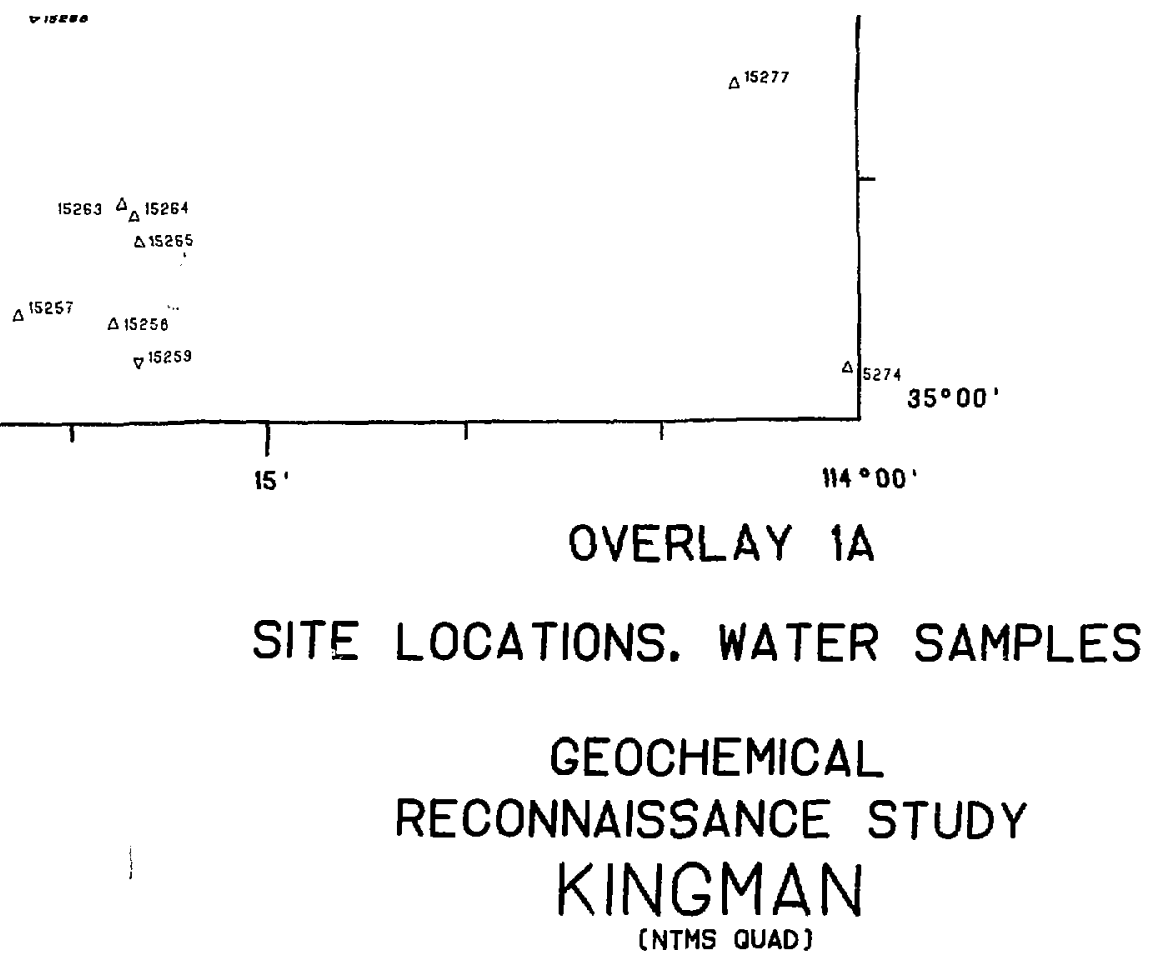




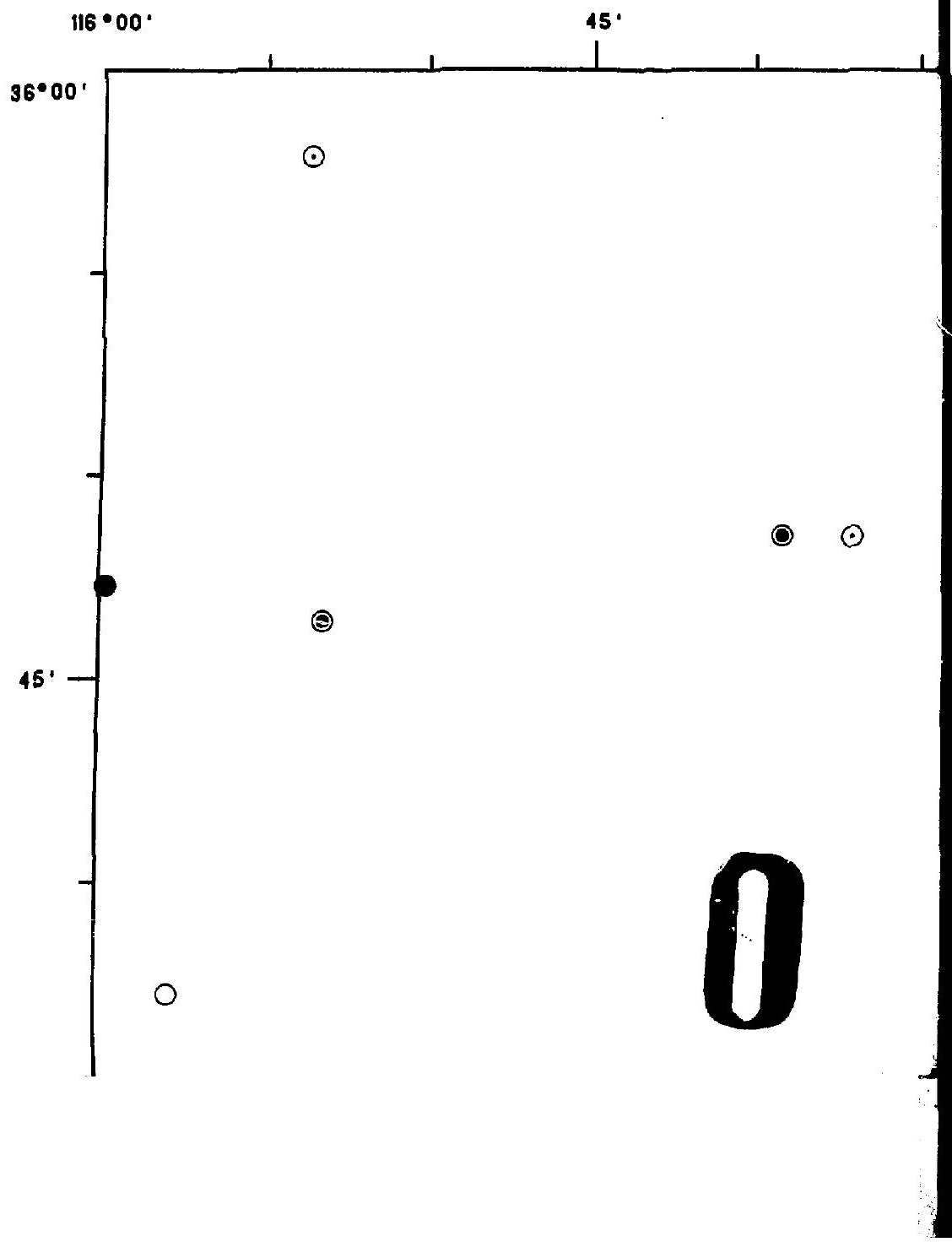


$\odot$

(2)

$\odot$

$\odot$

$\odot$ 
NI $11-03$

()

$\odot$

$\odot$

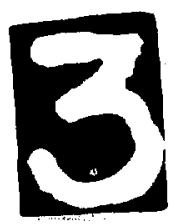


3

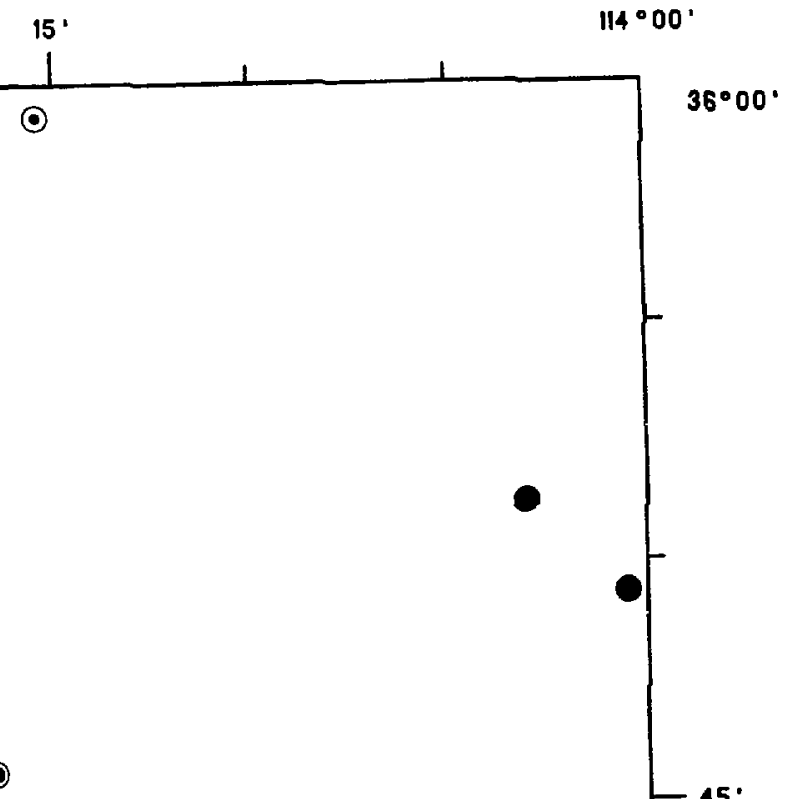

○

$\odot^{0}$

(2)

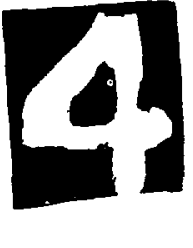




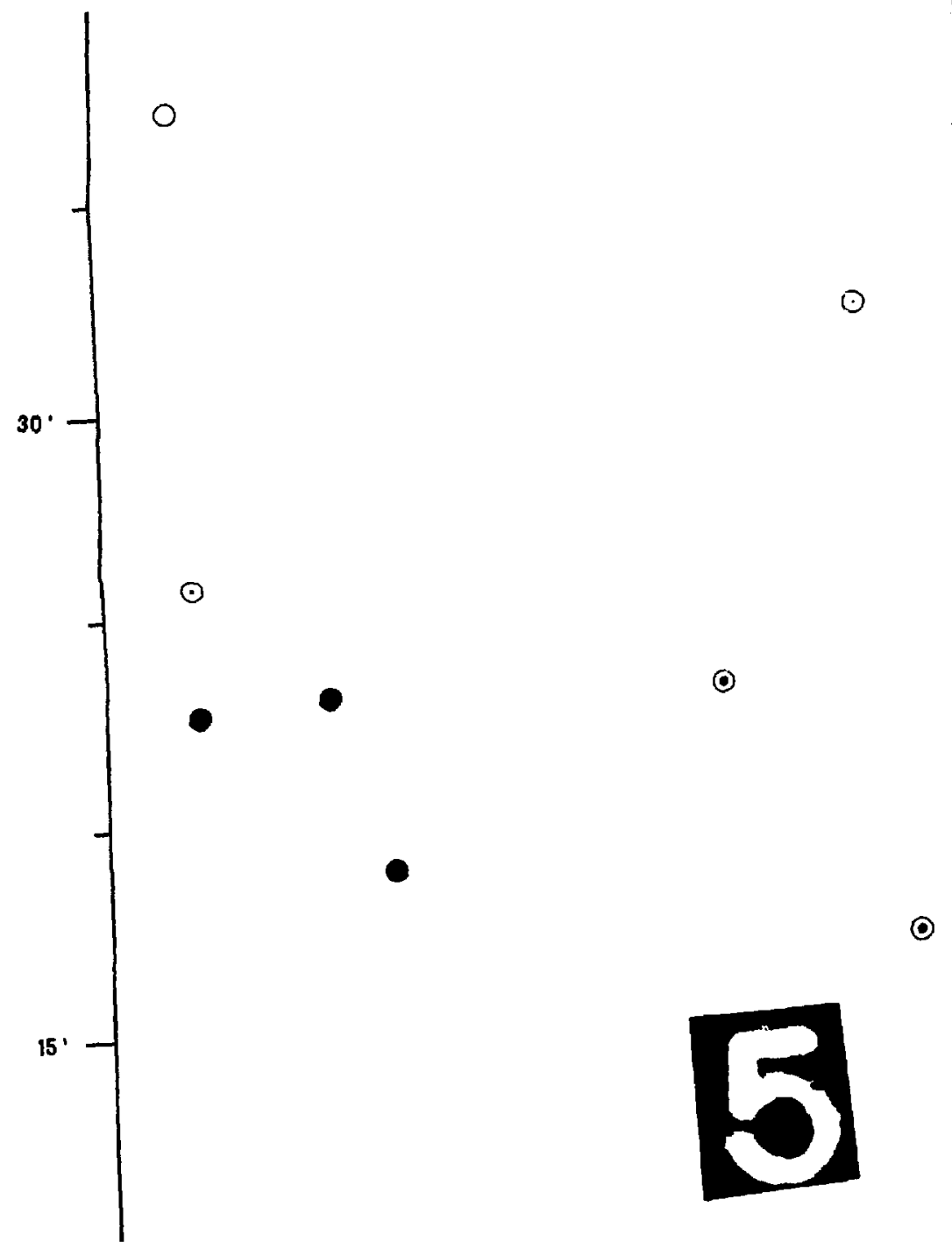


0

()

○

$\odot$

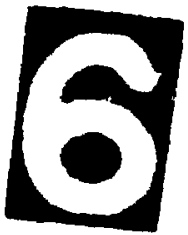


$\odot$

(

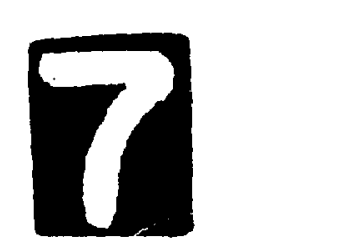

$\mathrm{O}_{\odot}$

0 


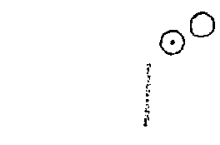

$\odot$
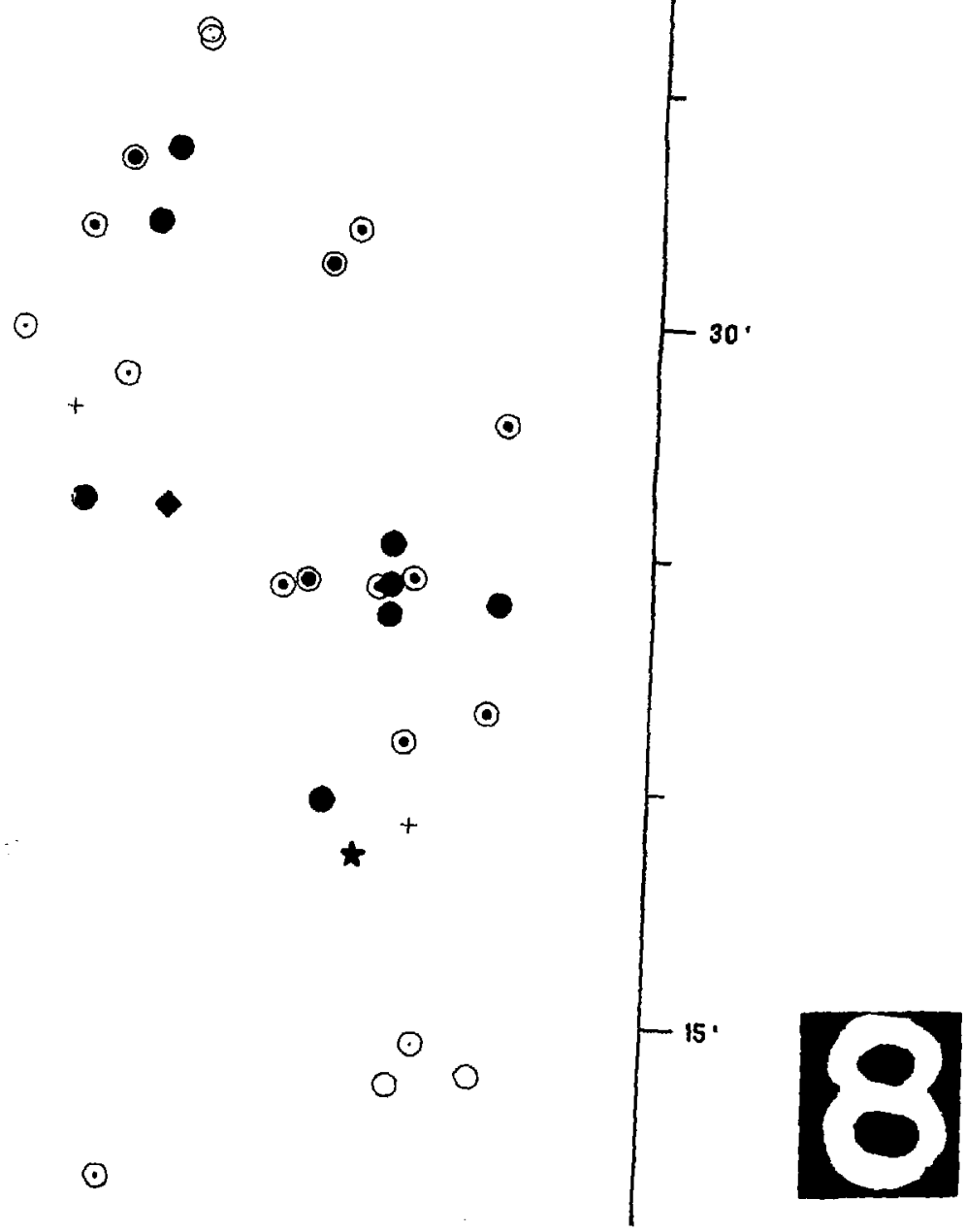


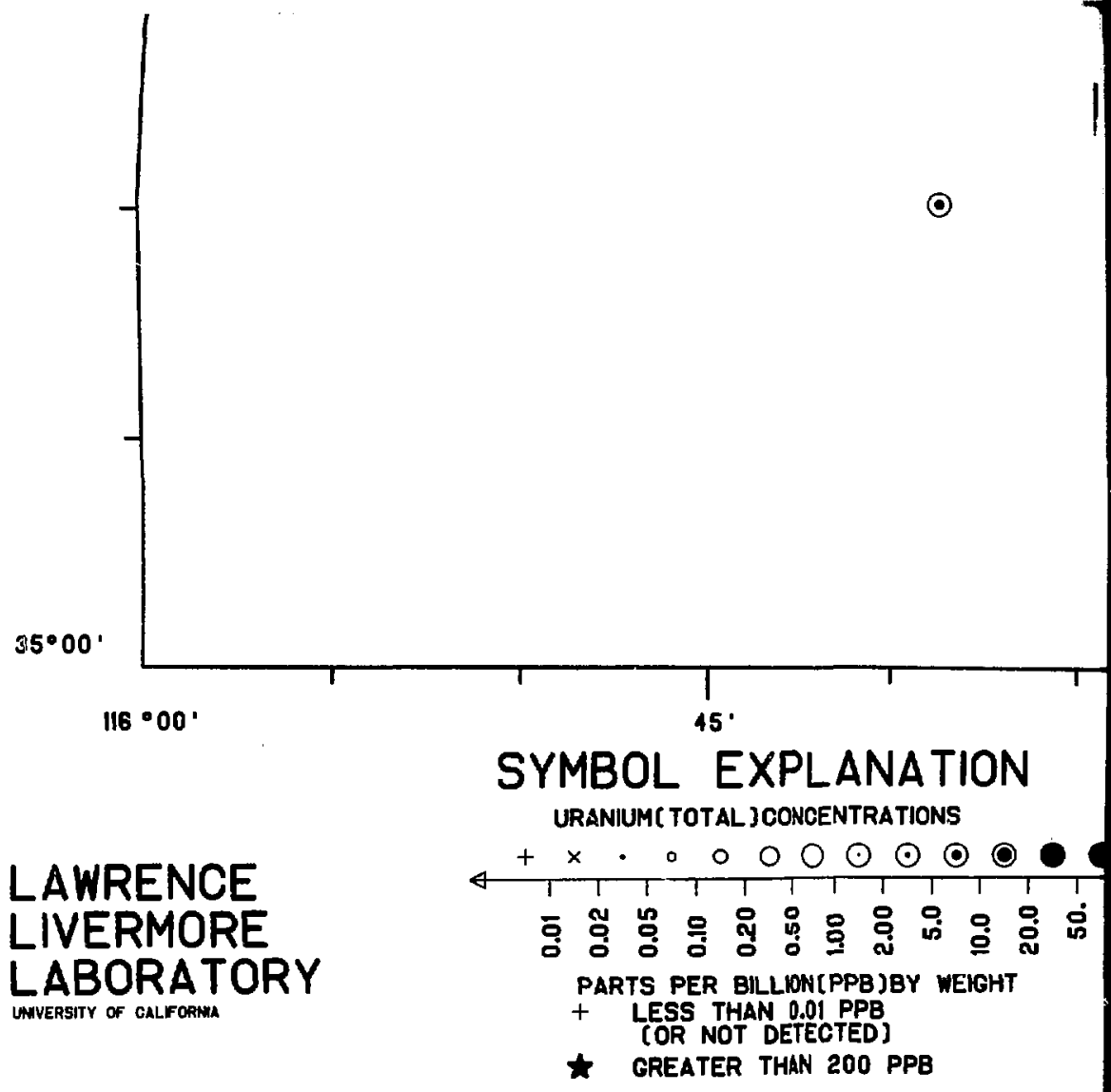

SER NO. LLL , NURE,HSSR $12,46,15$ U 07/20/78 
○

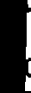
0 50000

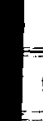

10

15

20

15

20 StATUTE MILES

25

30 KILOMETERS

\section{ENTRA
MPLES}




$$
\text { o־ } 0
$$

$\odot$

○ $\odot$

$0^{\circ}$

$\odot^{+}$
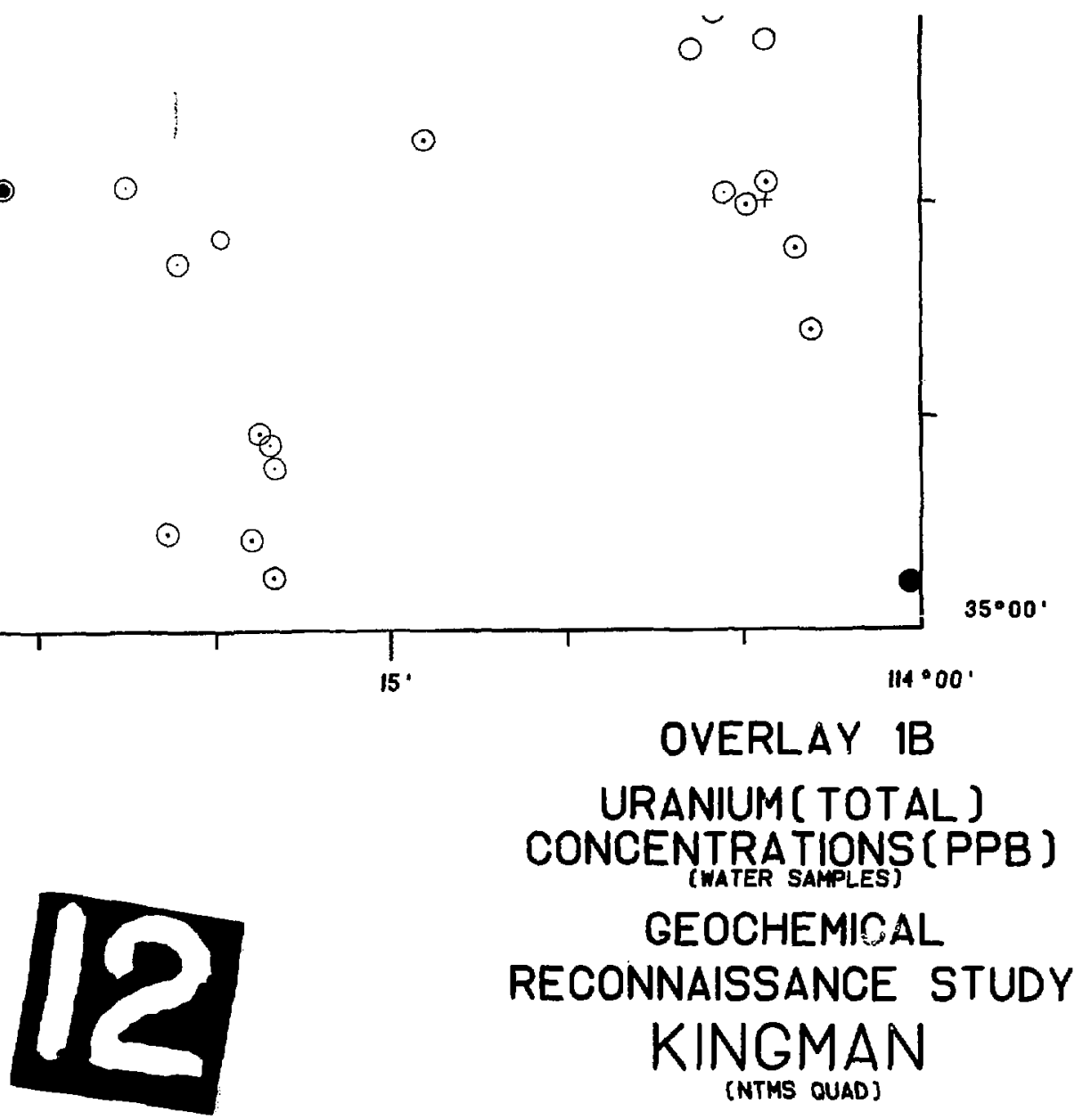

15. 


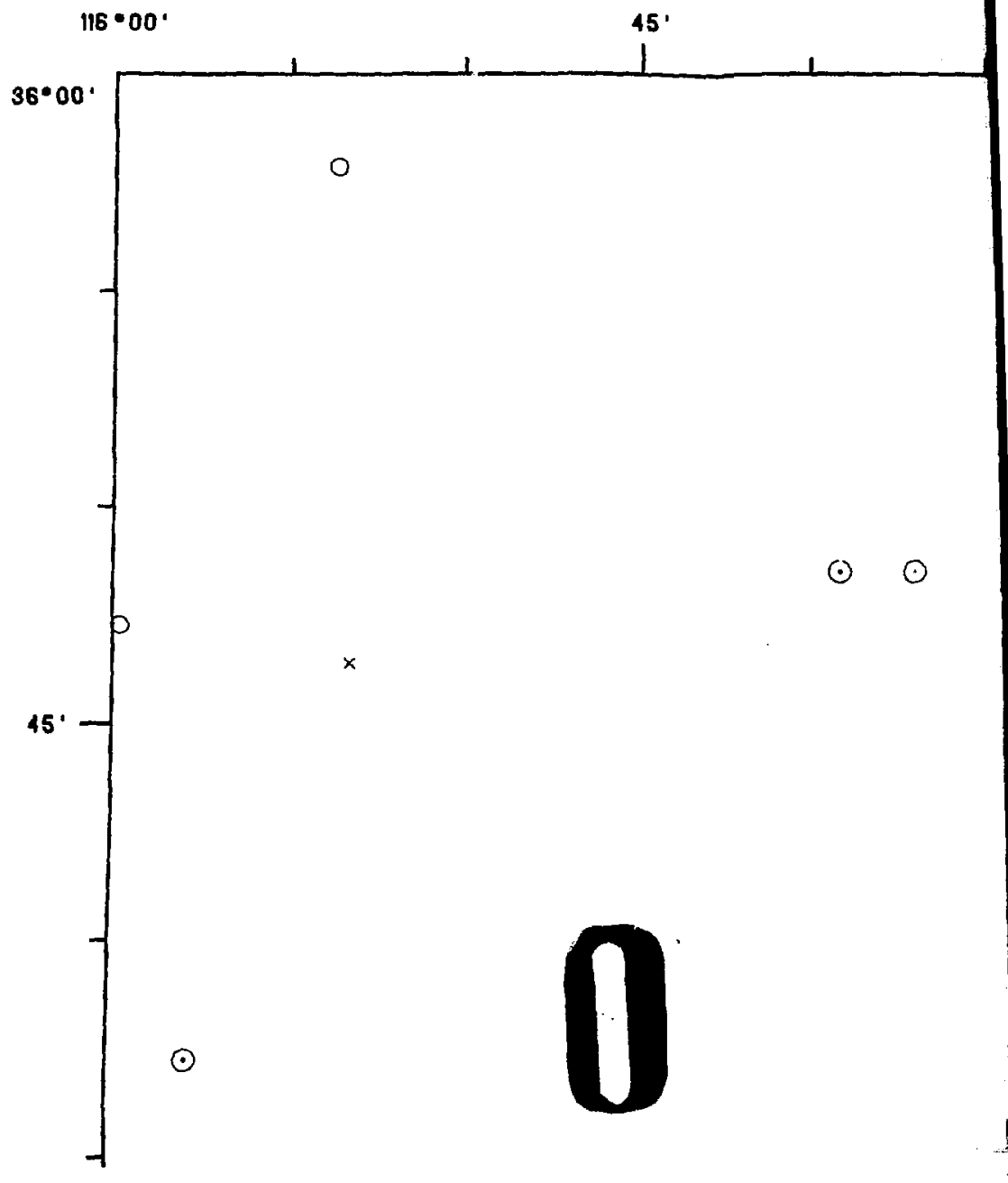


$\odot$

(2)

○

$\odot$

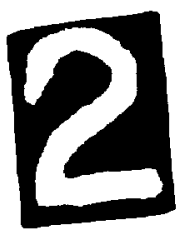

○ 
(5)

$\odot$

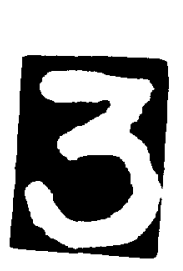


03

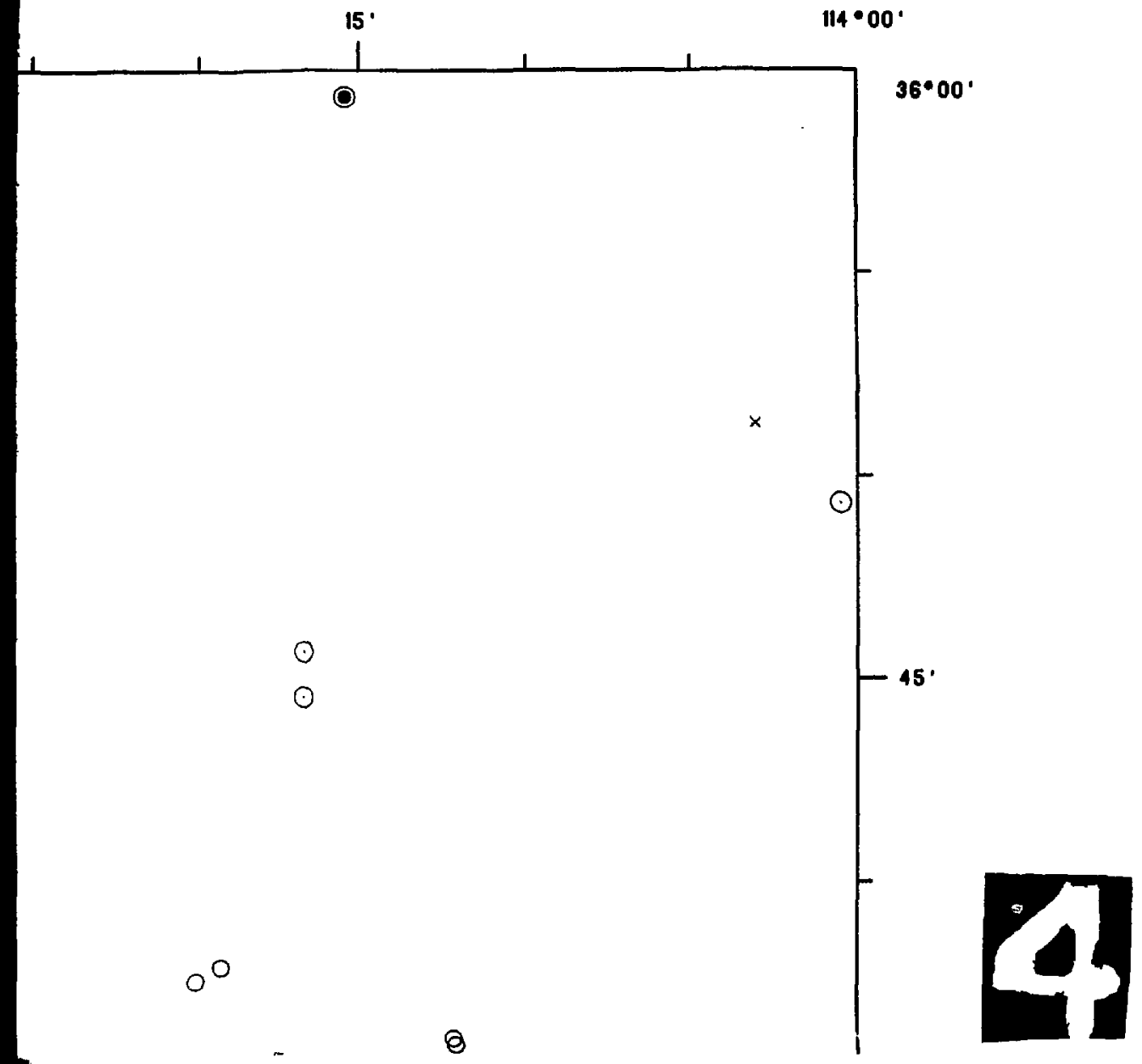




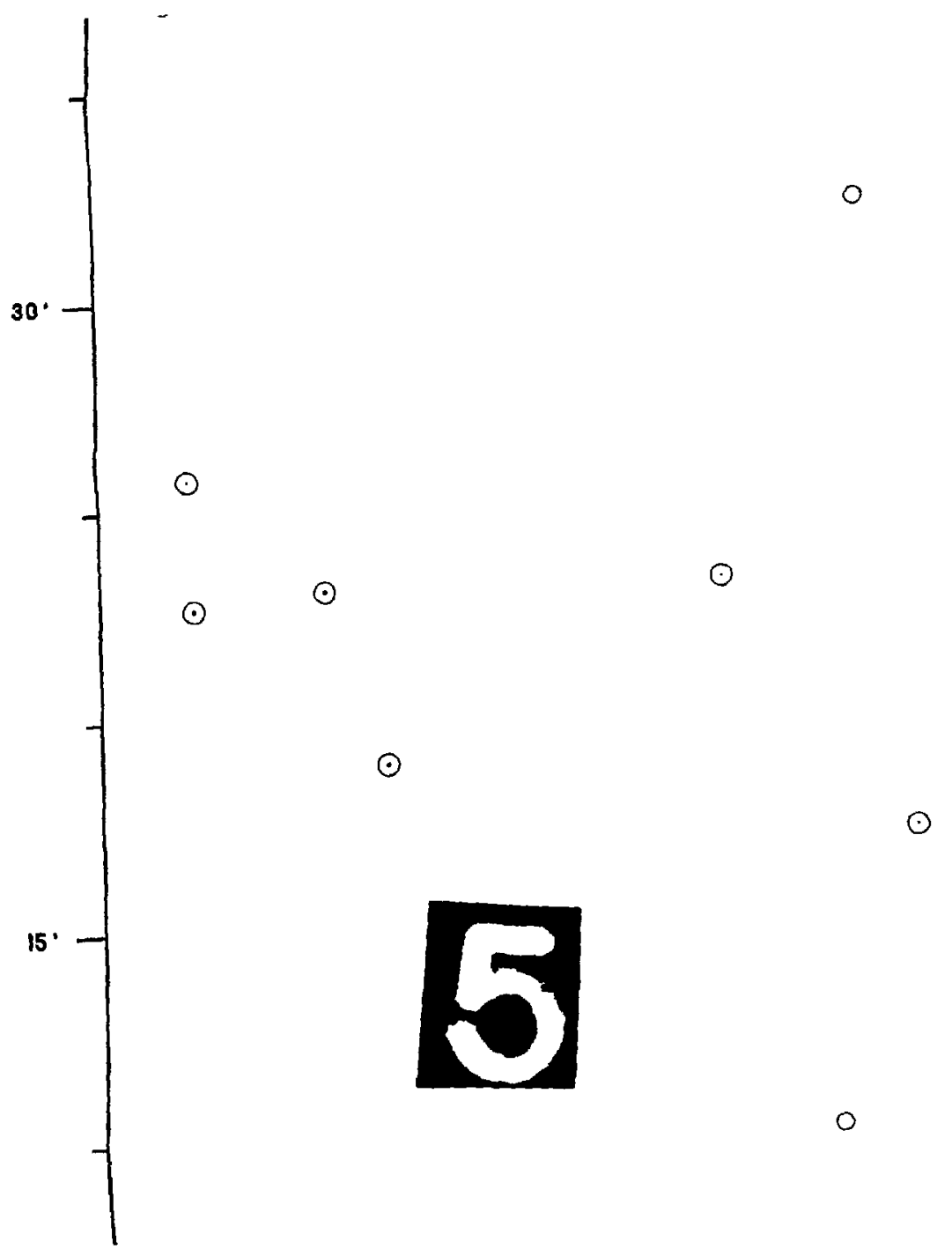


$\odot$

0

$\odot$

$\odot$

\section{$\theta$}

0

c

0

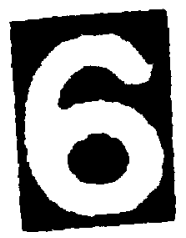


o

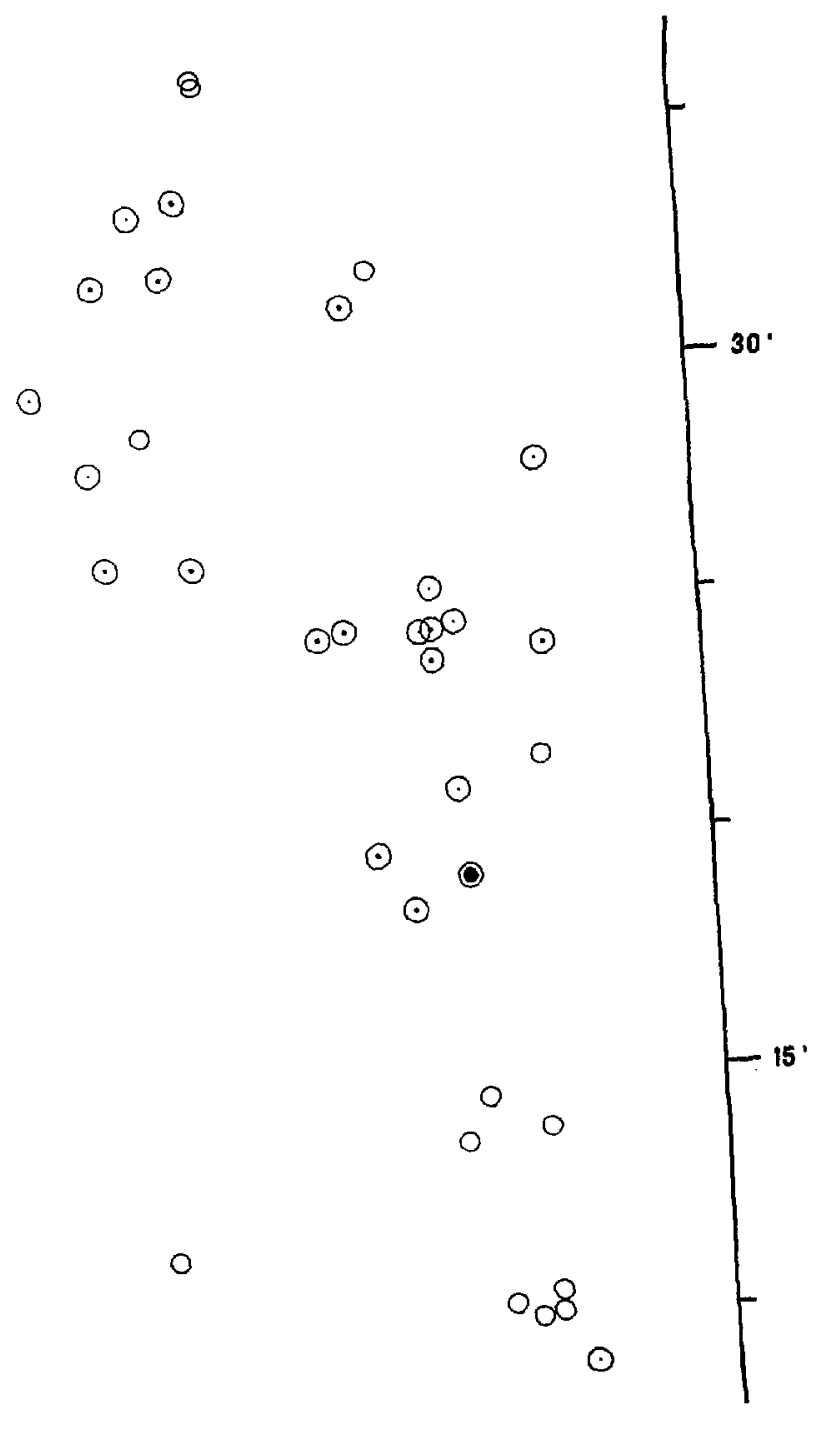




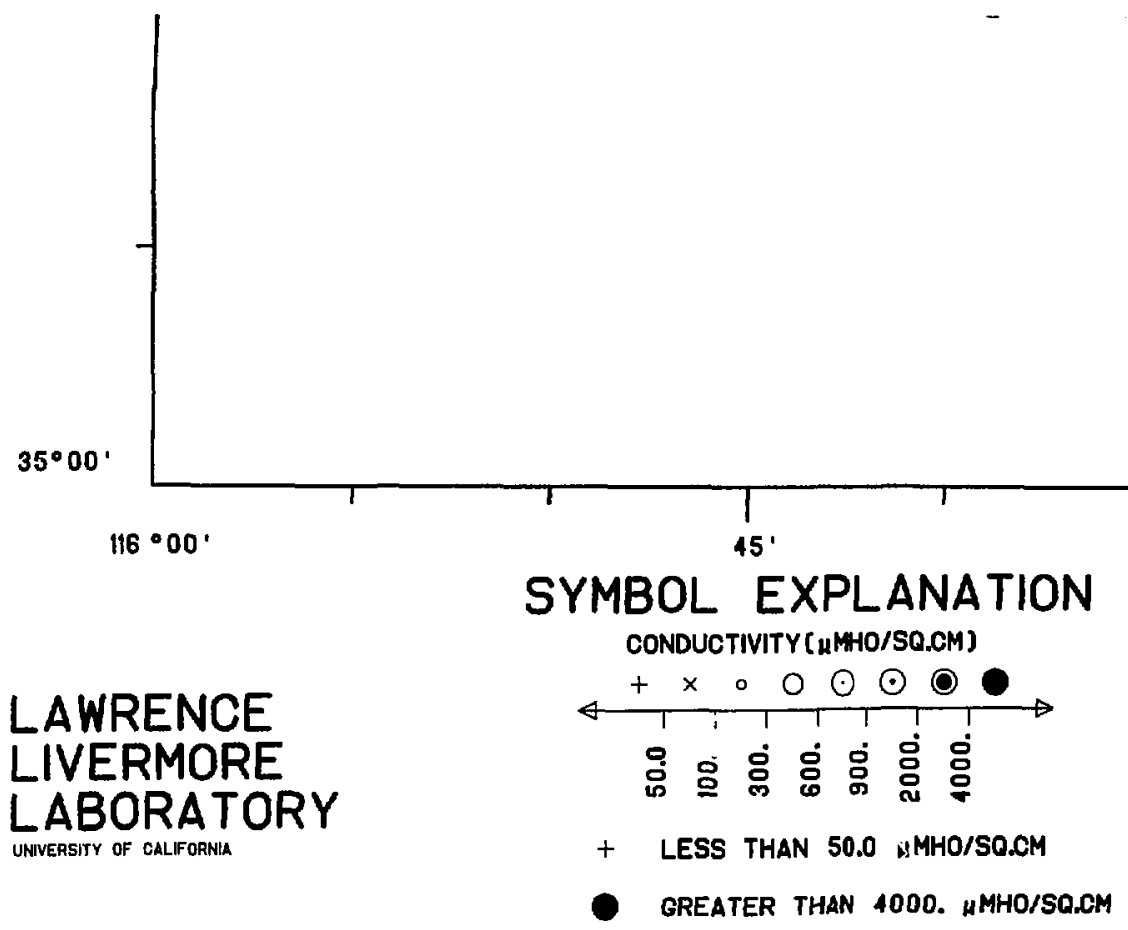

SER NO. LLL, INURE,HSSR 21:25:35 R 08/10/78 


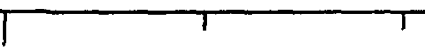

$30^{\circ}$

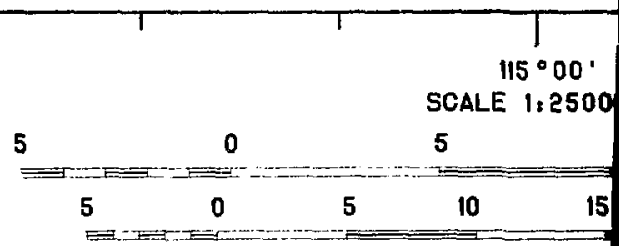

CONDUCTIVITY $C_{H} M$ WATER SAM

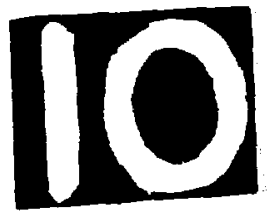




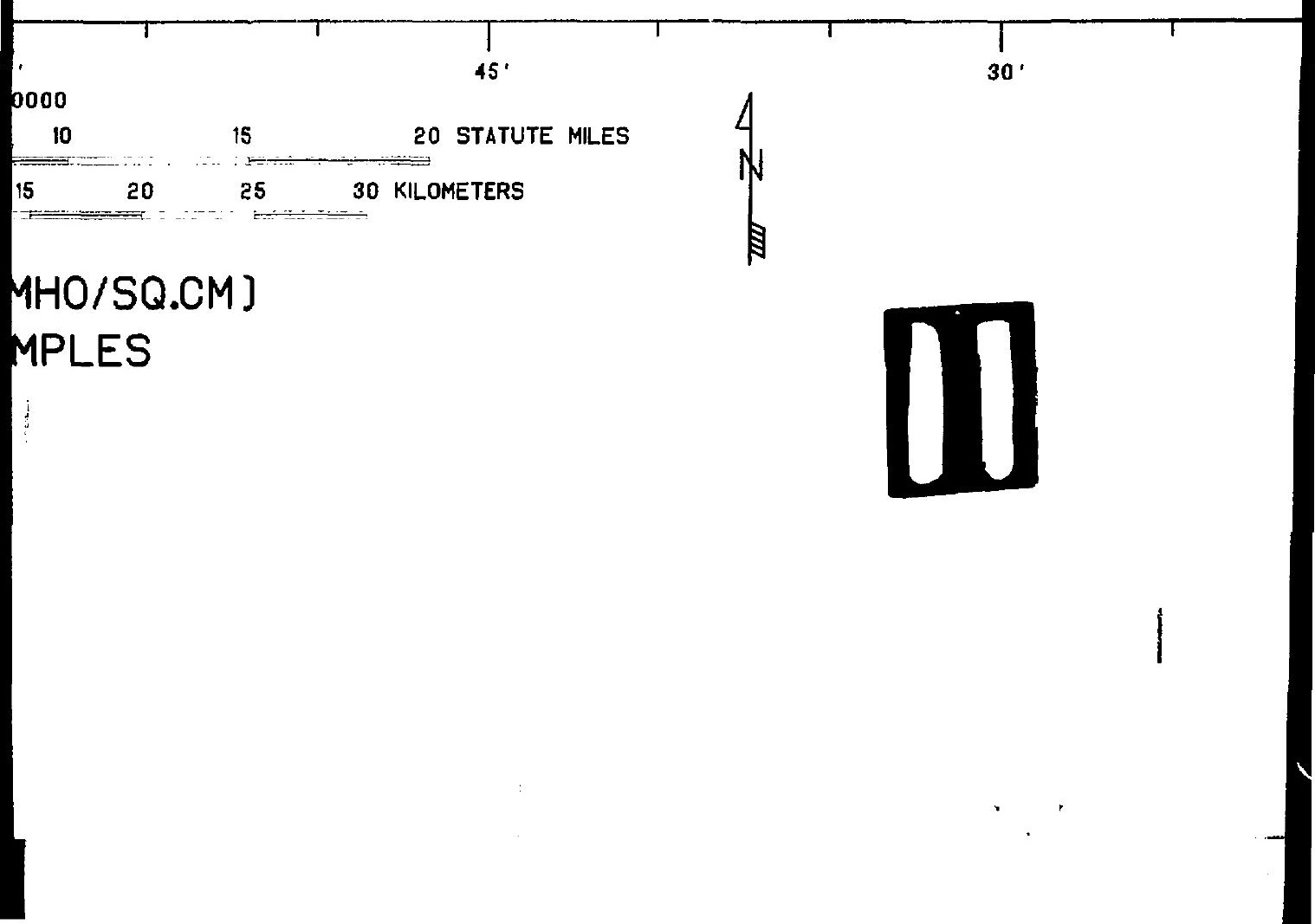



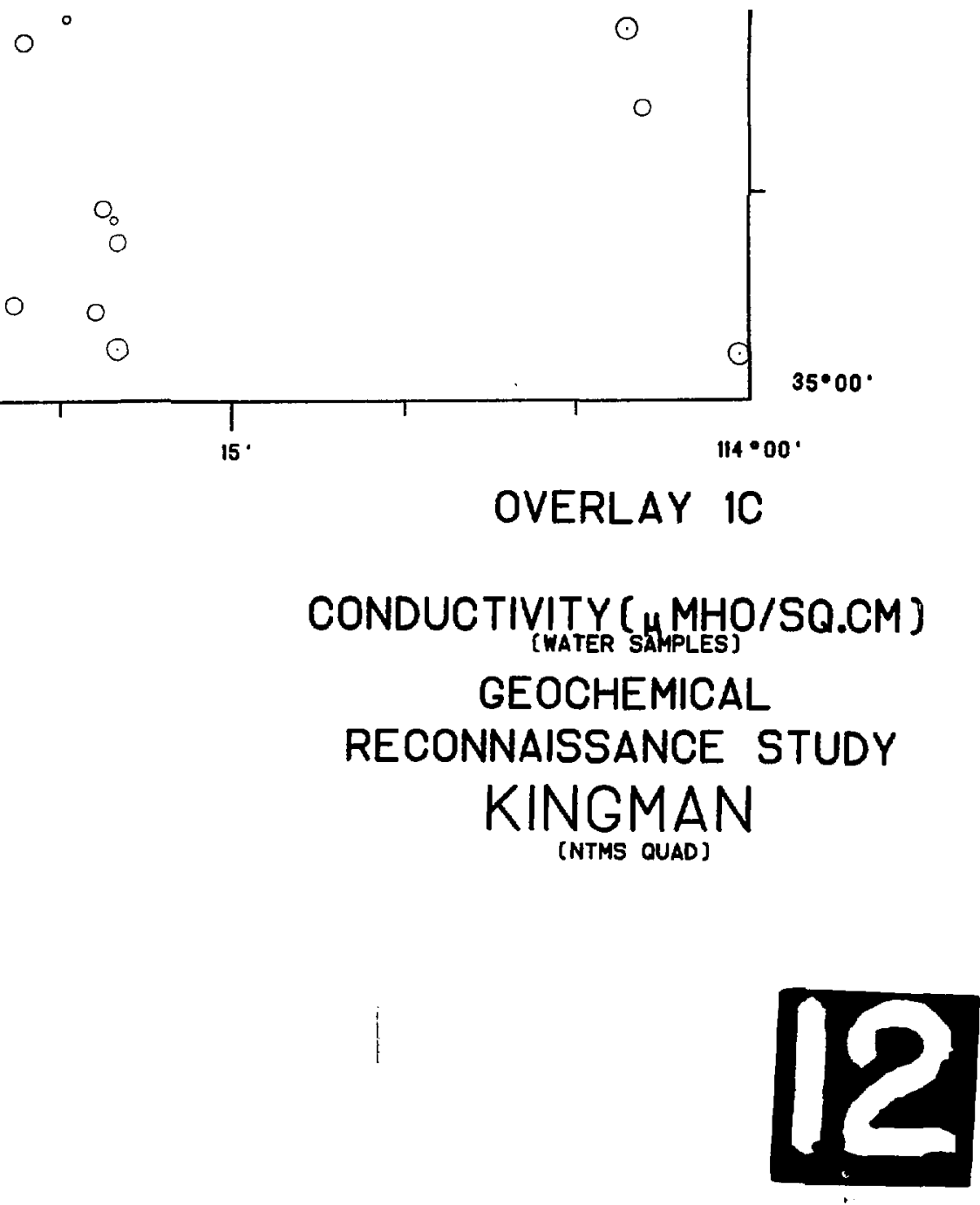


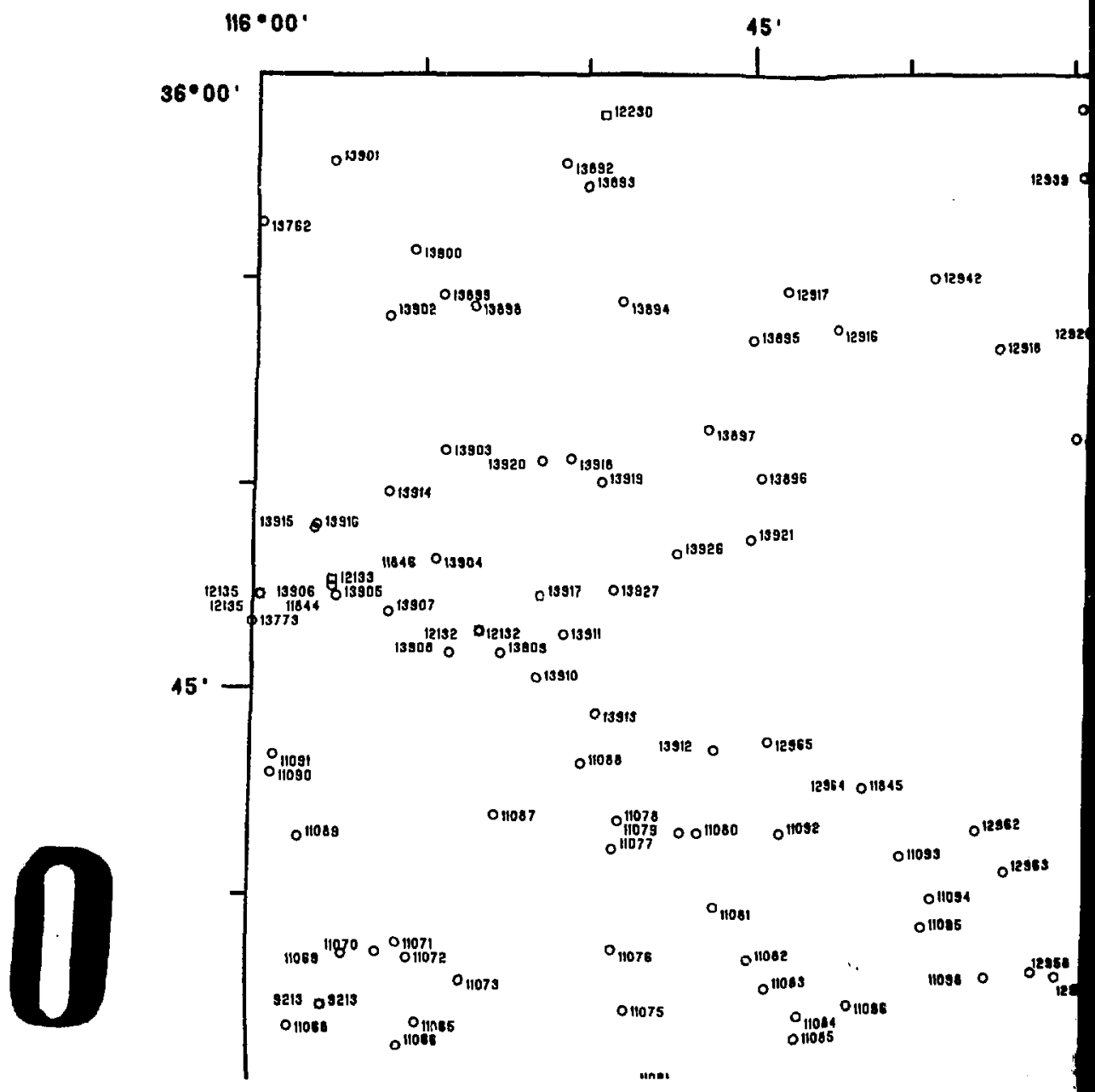




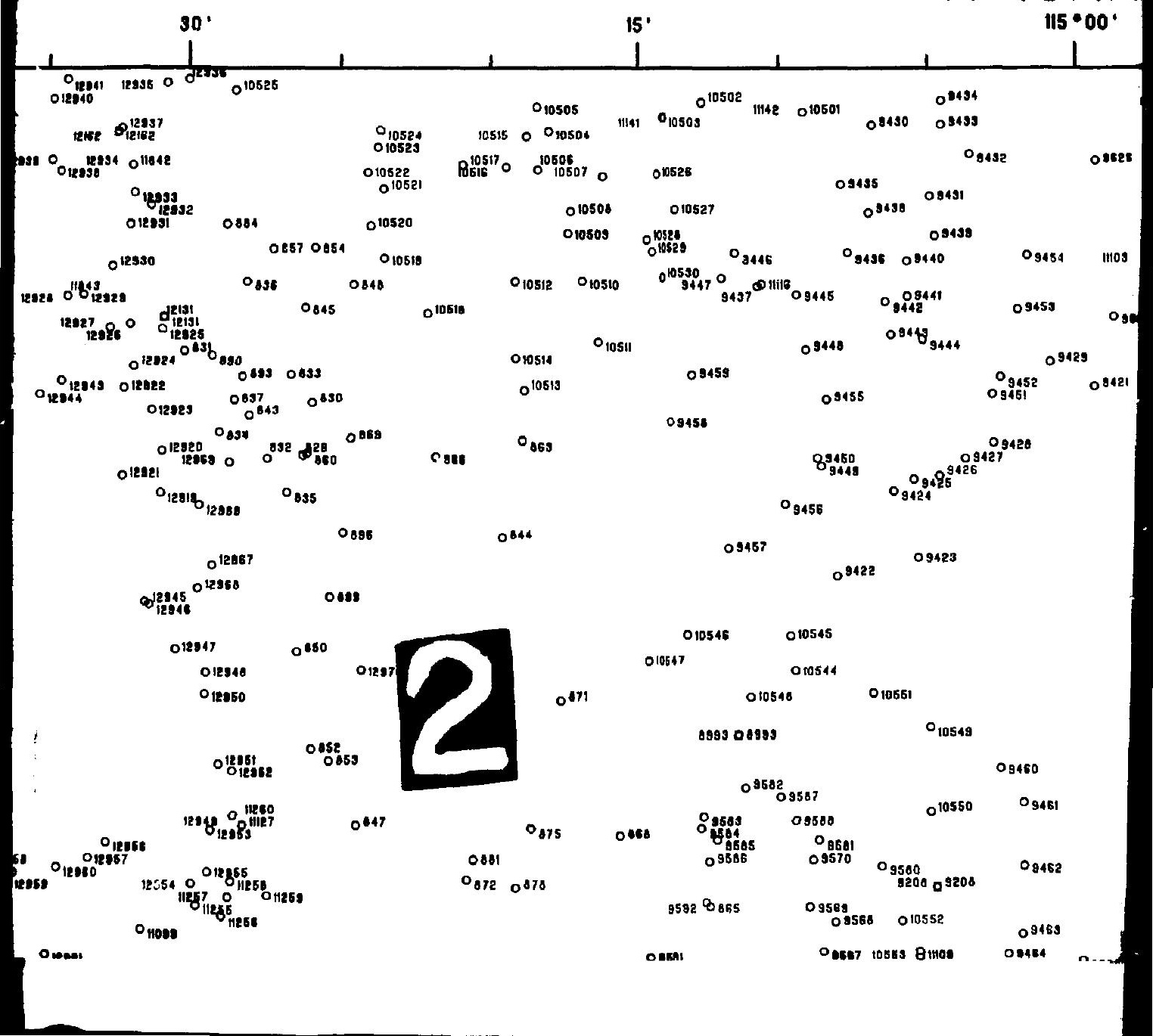


NI 11-03

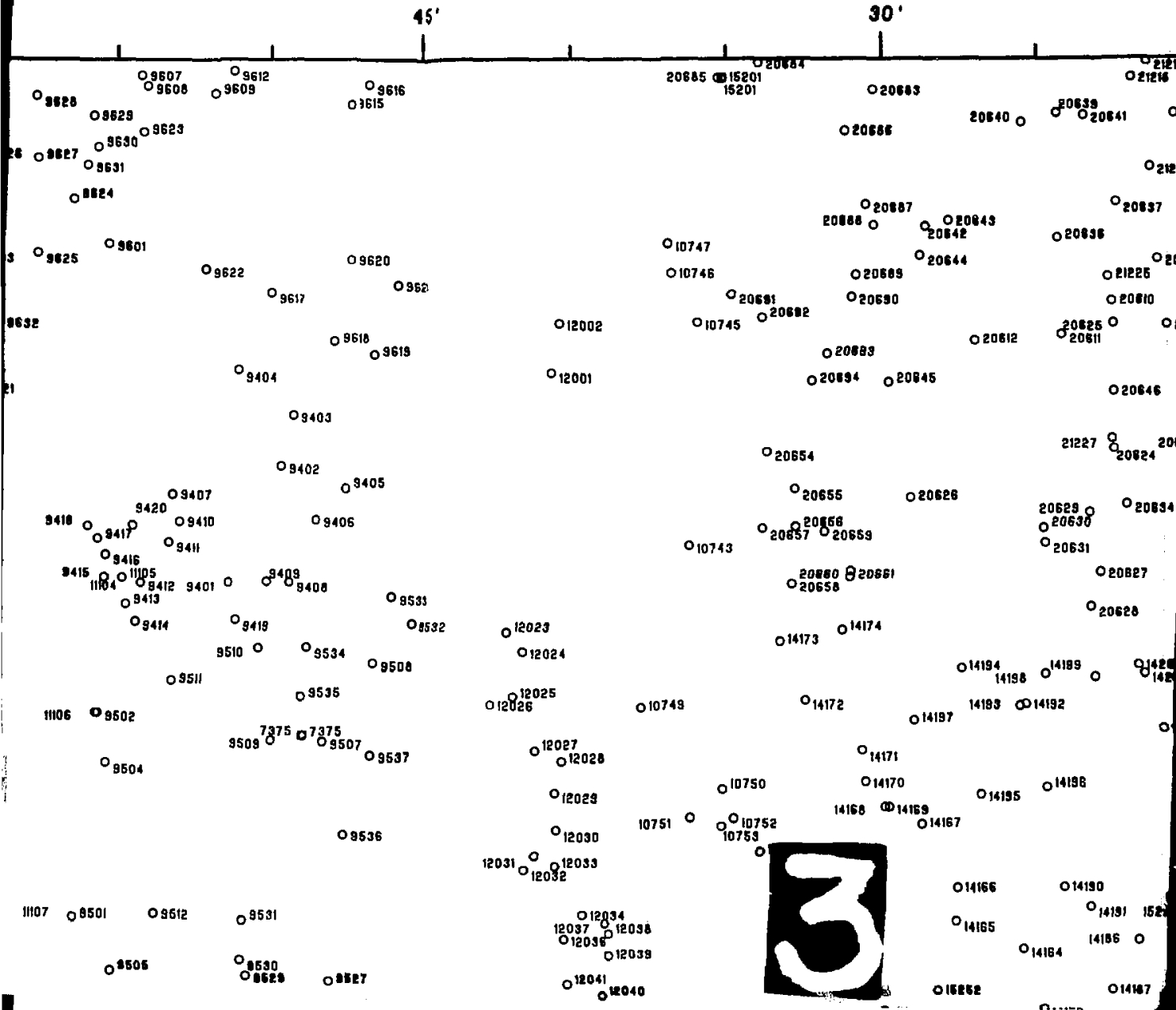




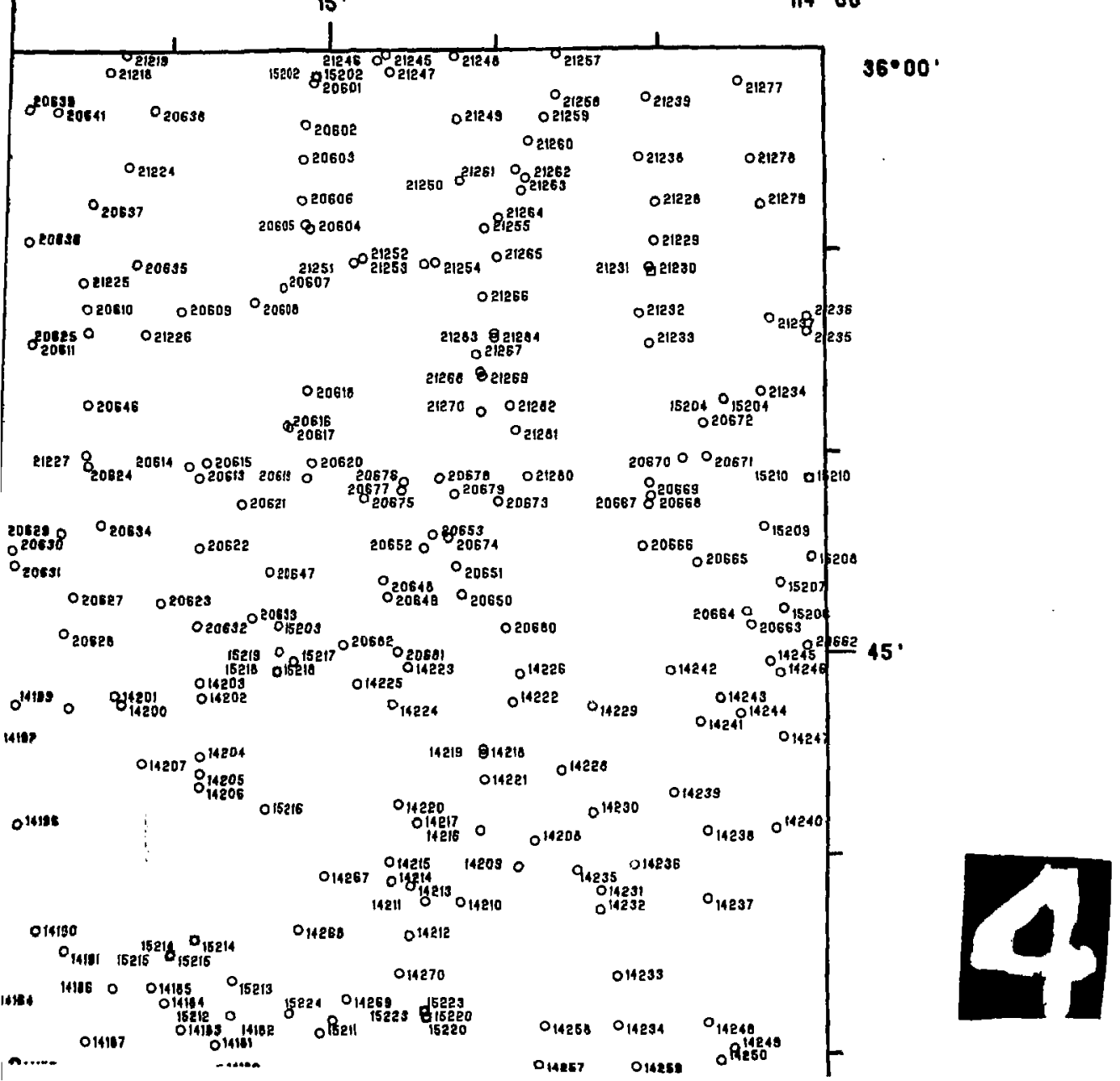




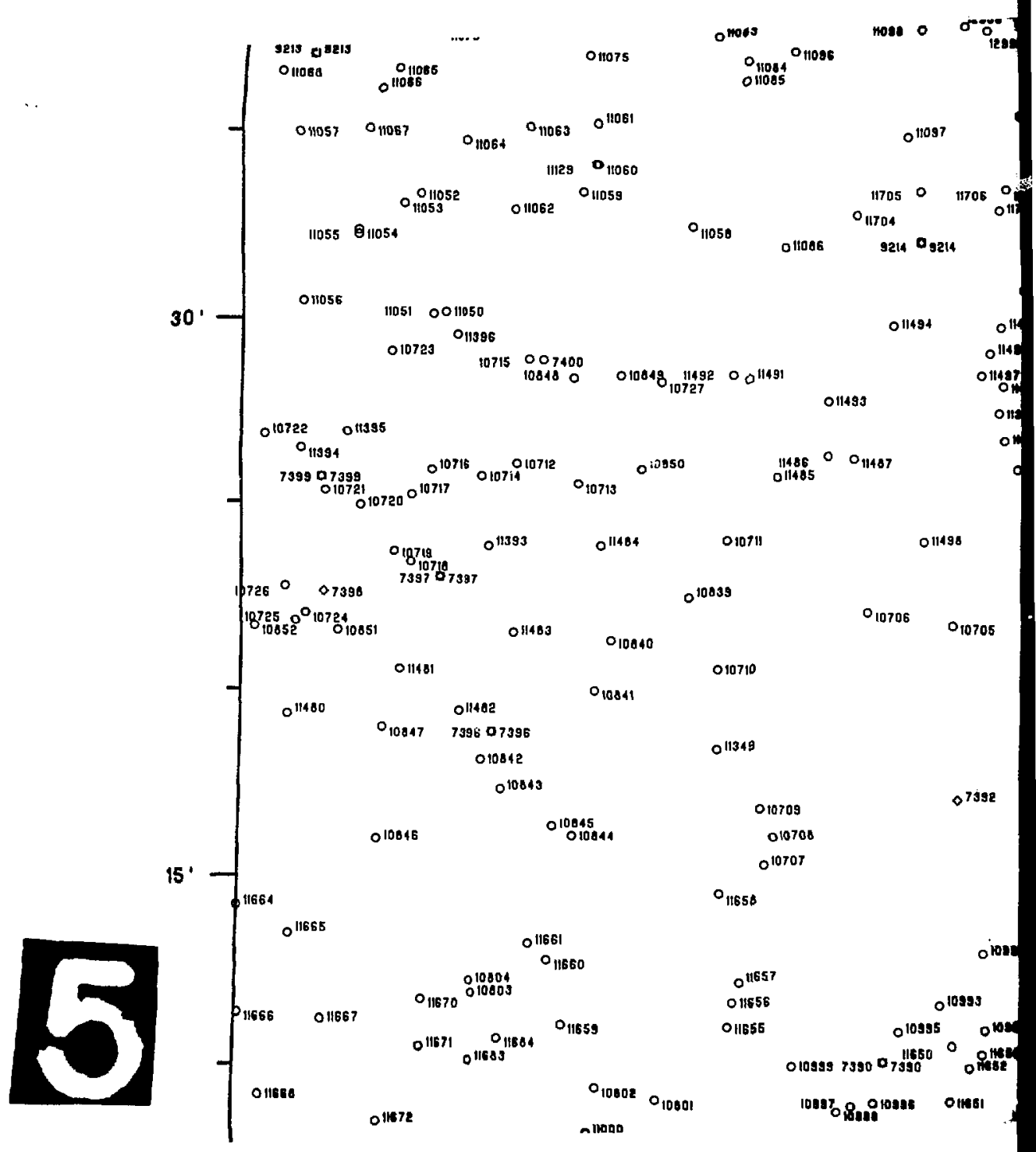




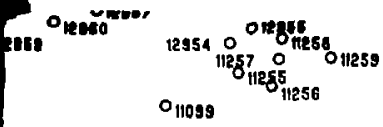

O12961 omoo $O_{11254}$

Omet $011701 \quad 09594$

osers

ot702 oll7os osss3

buss

mes

De7 ol14as onase ${ }^{9661}$

010599

inst

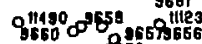

se15 O

A5० 10598

$10597 \circ 0^{10588} 010600 \quad 09662$

Ot1s4s oll500 ons44

105030010502

10603001802

O114as 9205 oto804

011345010701

$0^{\text {OISt6 }} \quad 0^{10505}$

$0_{10702}$

010808

$\operatorname{sess} 0$

09565

$0_{10703}$

$0^{10704}$

ol1347

onses
0001

0.820078

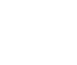

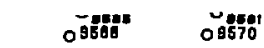

95928865

09580

920009200

O9569

$09568 \quad 0.0552$

O 9567 ioss3 811109

$0_{9579}$ O9578 $_{9590}$ $0994 \circ 0 \begin{gathered}9564 \\ 09565 \\ 09565\end{gathered}$

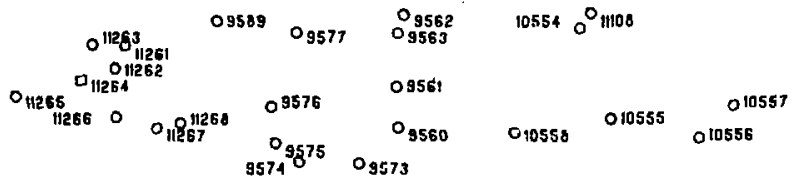

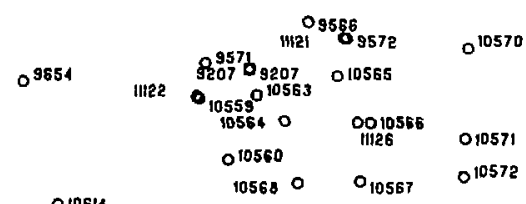

010614

010573

$0^{10568}$

$0_{10574}$

$O_{10613}$

$0_{10562}$

010561

$0_{10575}$

0.0576

09463

09464

$O_{9520}$

$0_{10585}$

$0^{10586}$

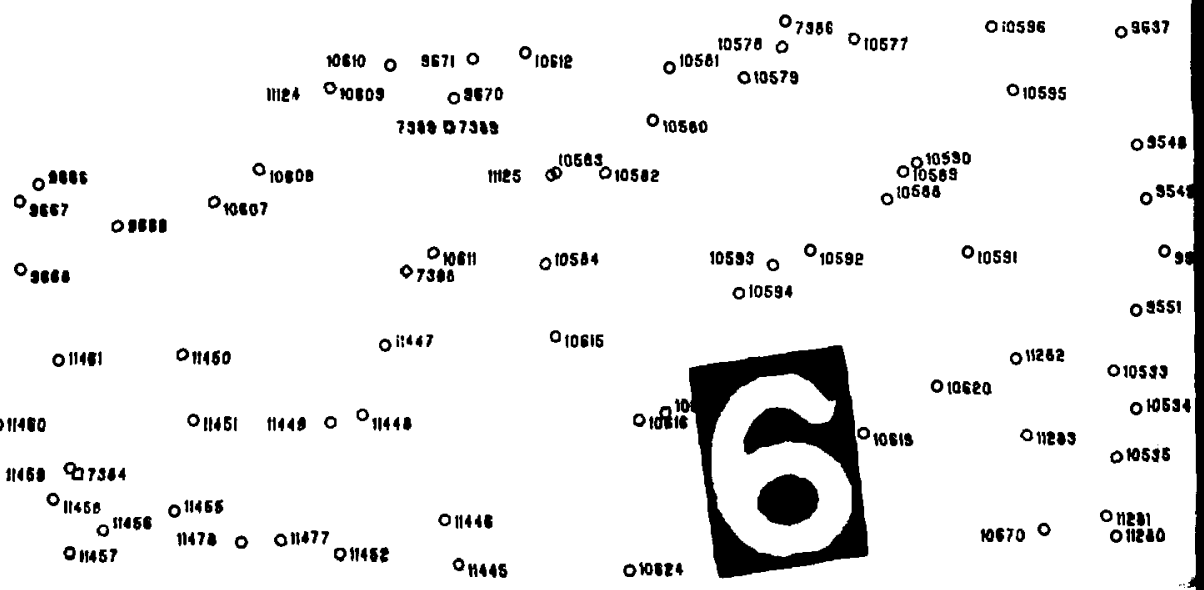

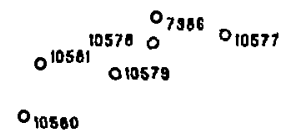

010587 


$$
\text { IEosi } 0_{12082}^{\circ}
$$

$11107 \quad 0^{9501} \quad 09512 \quad 0^{9531}$

$$
0^{9505}
$$$$
\begin{aligned}
& \text { O9530 } \\
& \text { O9529 }
\end{aligned}
$$$$
08527
$$$$
09526
$$

00510

$$
0_{9506} 0_{9515}^{9516}
$$

\section{ossis}

ossit

$$
0^{9513}
$$

09524

$0^{12043}$

$$
\begin{aligned}
& 09528 \\
& \text { O9521 } \\
& 09514 \\
& \text { 09633 } 96400_{11113}{ }_{0}^{099676} \\
& \text { O963ם O } 6640 \\
& 946689465 \\
& \text { Og649 }
\end{aligned}
$$

09467

09673

09695

o 0630

$$
5630009651
$$$$
94950
$$$$
09496 \quad 09497
$$$$
\text { O } 8498
$$

$$
\text { 95ss o gog4t }
$$

$$
\text { O9552 }
$$

03499

$$
09538
$$

\section{4}

09500 $94600 \quad 09469$ $9541 \circ \quad 09474$

${ }_{9543} \circ 0_{9544}$

$$
\begin{gathered}
\text { O5547 } \\
954509453 \\
09646
\end{gathered}
$$

010581

o 10658

$$
\begin{aligned}
& \text { I1117 O5553 } \\
& 0.5520_{9475} \\
& 9654 \text { of1118 } \\
& 0.5555 \\
& 0.555
\end{aligned}
$$$$
0_{9542}^{09472}
$$

$$
\begin{aligned}
& \begin{array}{c}
012934 \\
12037 \\
012036
\end{array} \\
& 012039 \\
& 0^{12041} 0^{12040} \\
& 012068 \\
& \begin{array}{c}
\text { O12048 } 012067 \\
\text { ol2066 }
\end{array}
\end{aligned}
$$

Grored

$$
\begin{aligned}
& 014165 \text { O14190 } \\
& 0_{14165} \\
& 0,14164 \\
& \begin{array}{l}
0_{14191} \\
141860
\end{array} \\
& 0^{015253} \begin{array}{ccr}
015252 & 014187 \\
0^{14161} & 0_{14156} & O_{14160} \\
O_{14160} & 0.14157 & 014158
\end{array}
\end{aligned}
$$

010767

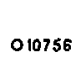

010756

$014158 \quad 4462^{0 / 6180}$

\section{9}

$010760 \quad 014159$

012046

$10531 \quad 810630$

o poses
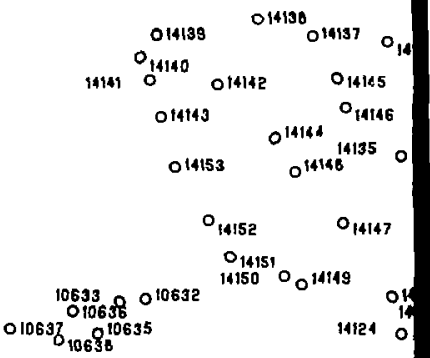

$$
0_{10639}^{014941} 014930
$$



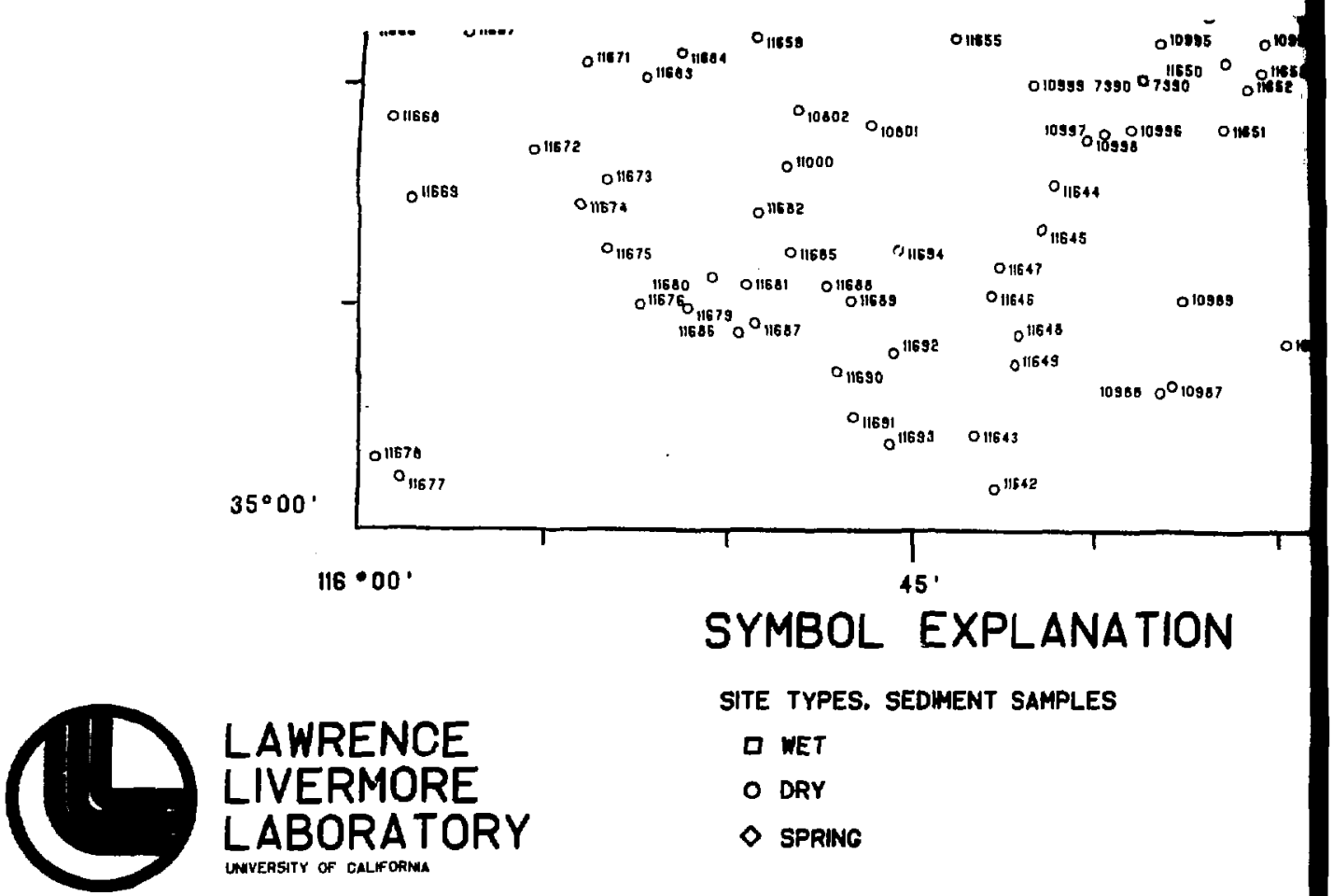

\section{SYMBOL EXPLANATION}

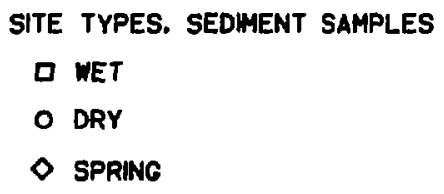

UNMVESTTY OF CALIFORMA

SER NO. LLL , NURE, HSSR 14:15:15 R 07/29/70

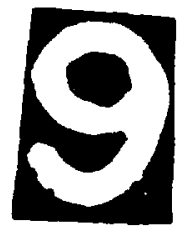




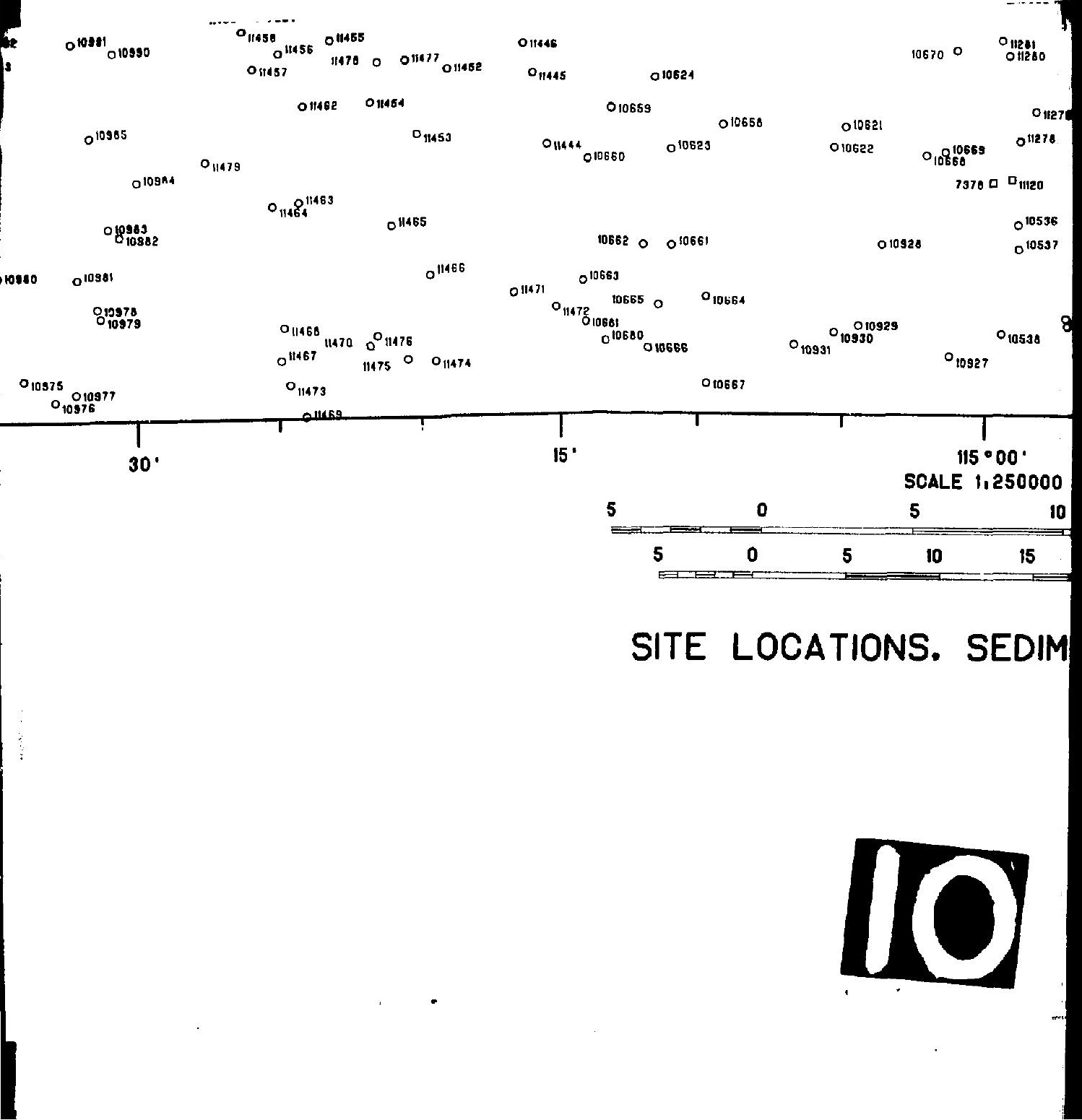




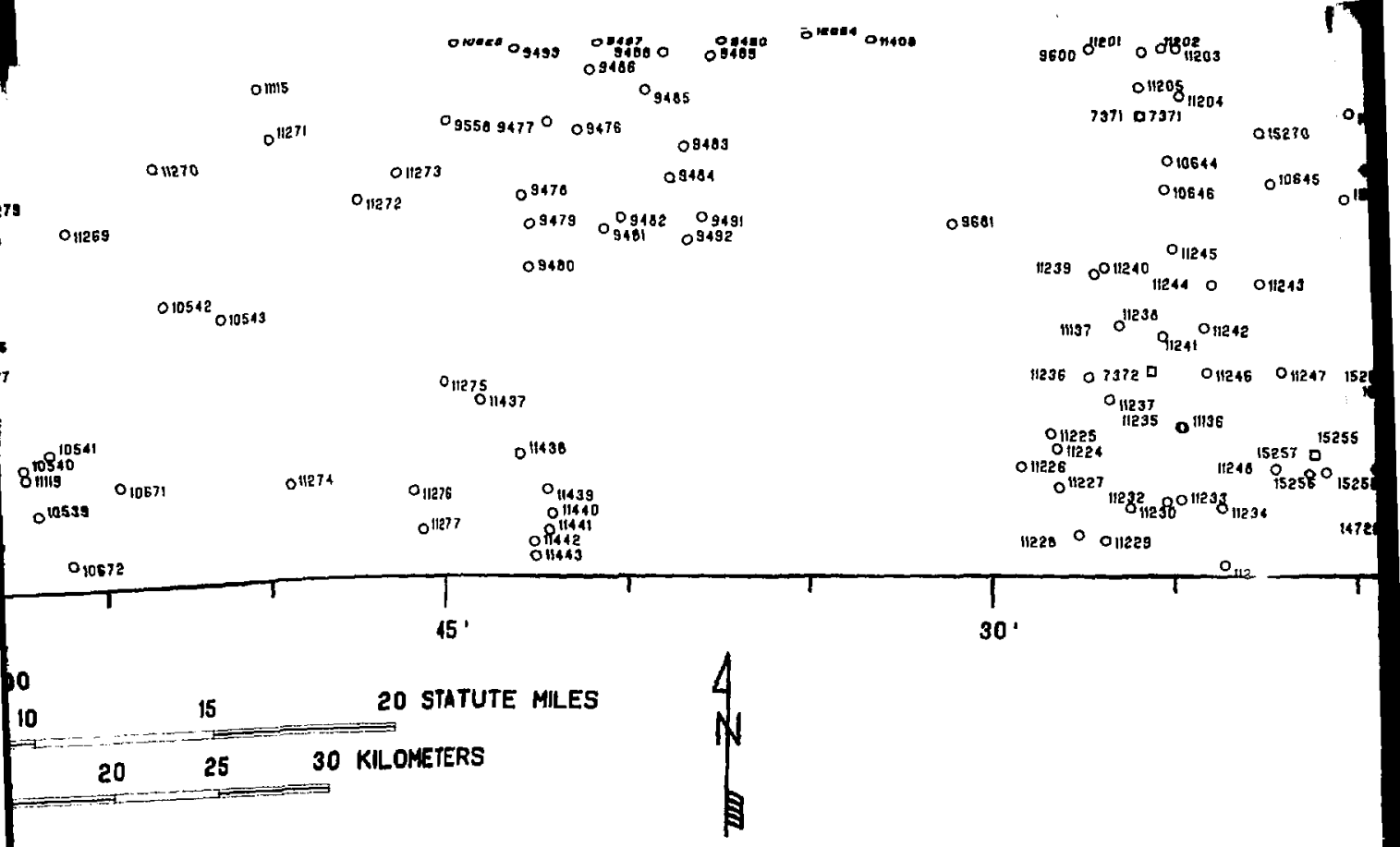

\section{MENT SAMPLES}





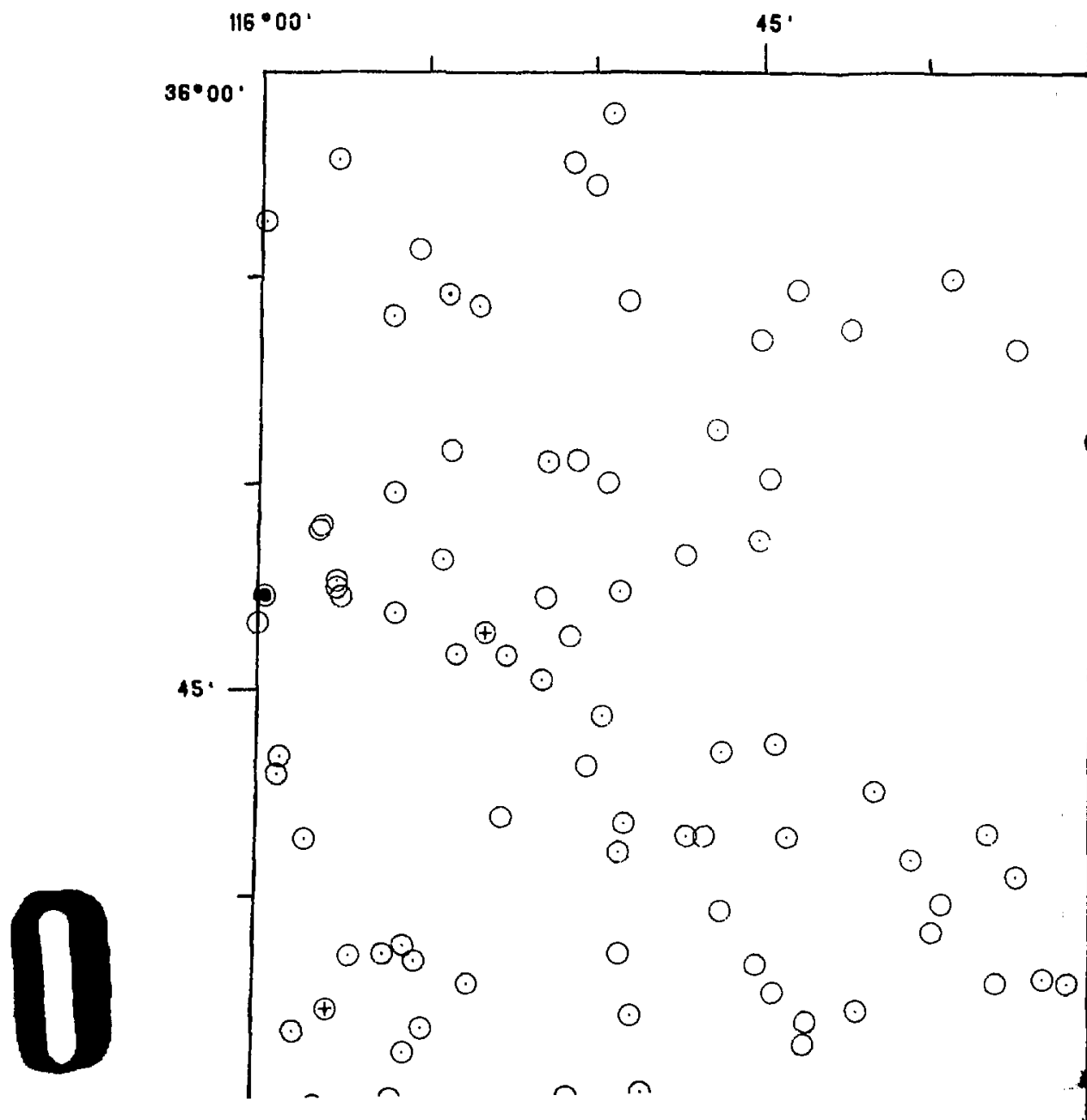




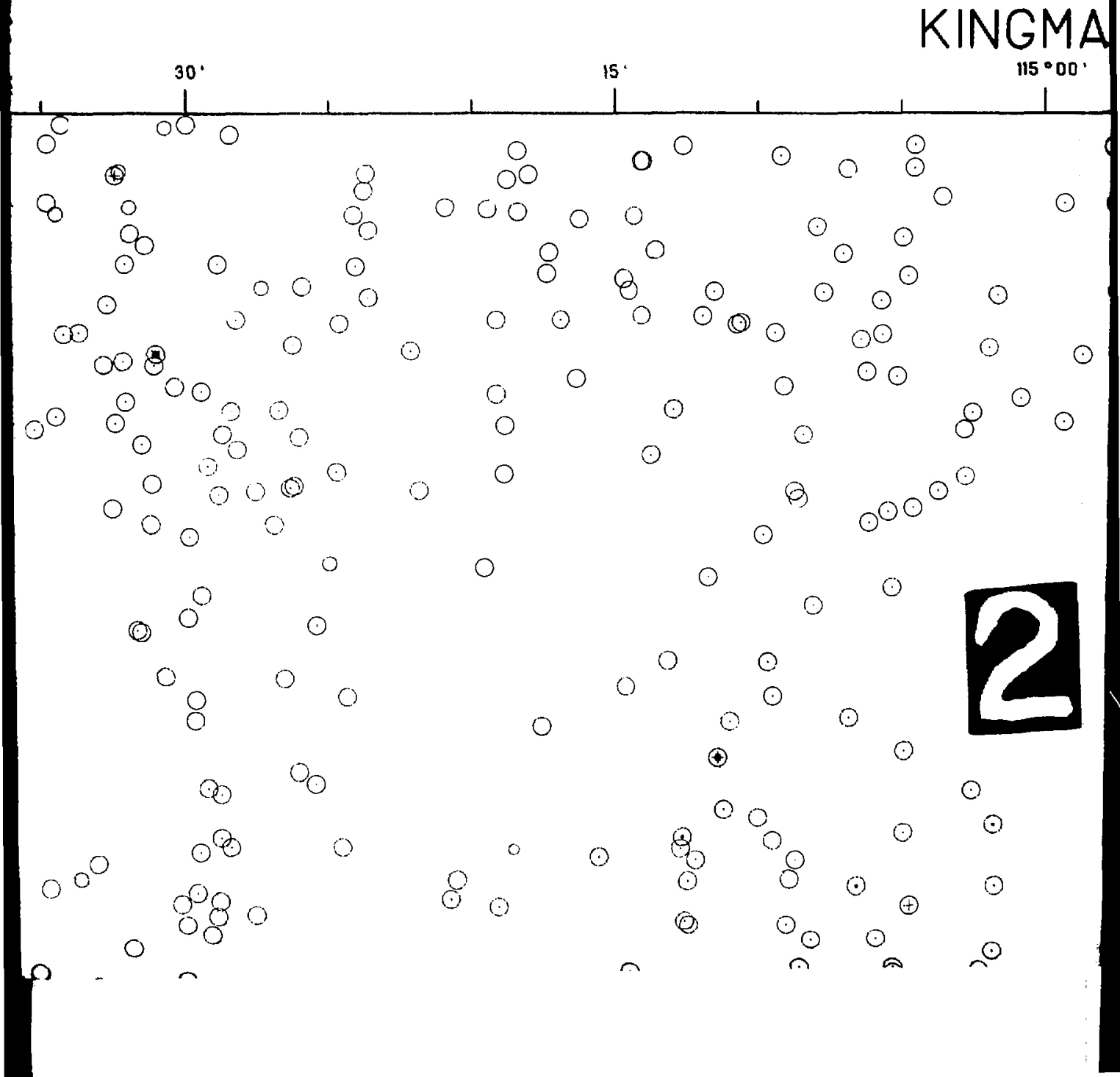


${ }_{\odot}^{\circ} \odot^{8} \odot^{8} \odot^{\circ}$

0

$\odot \odot$

$\odot$

o

() 0

$300^{\circ} 0^{\circ}$

80

$\odot$

$\odot$

$\odot \odot$<smiles>OCCO</smiles>

$\odot$<smiles>O[Os]</smiles>

0

$\odot$
$0^{\odot}$

$45^{\circ}$

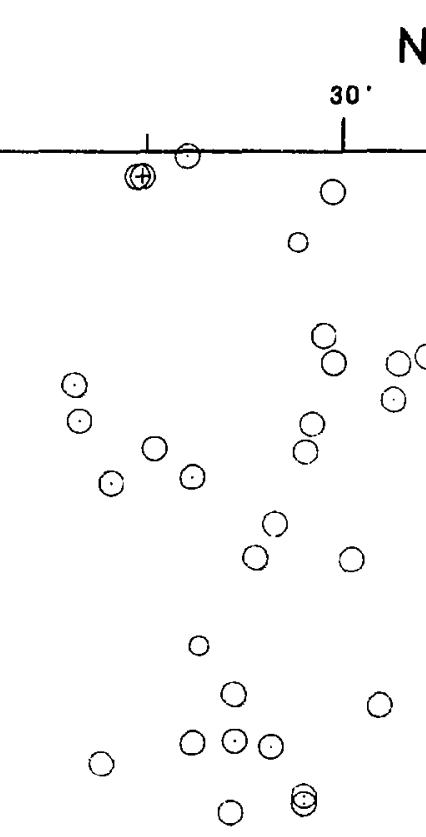

○

o

$\circ \quad \circ \circ$

0

$\odot$

80

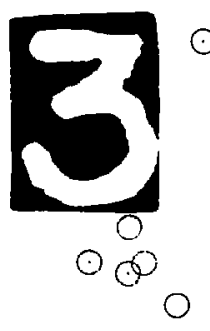

08 $\odot \odot$

O

0

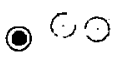

o

$\circ 0$

○

o

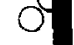

0

8

$8^{\odot} \odot$

$\odot$

$00 \%$

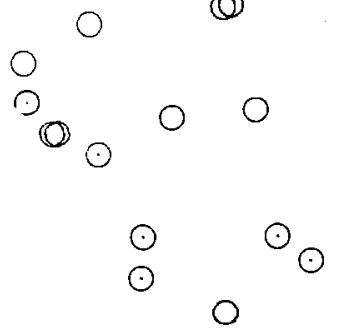


3

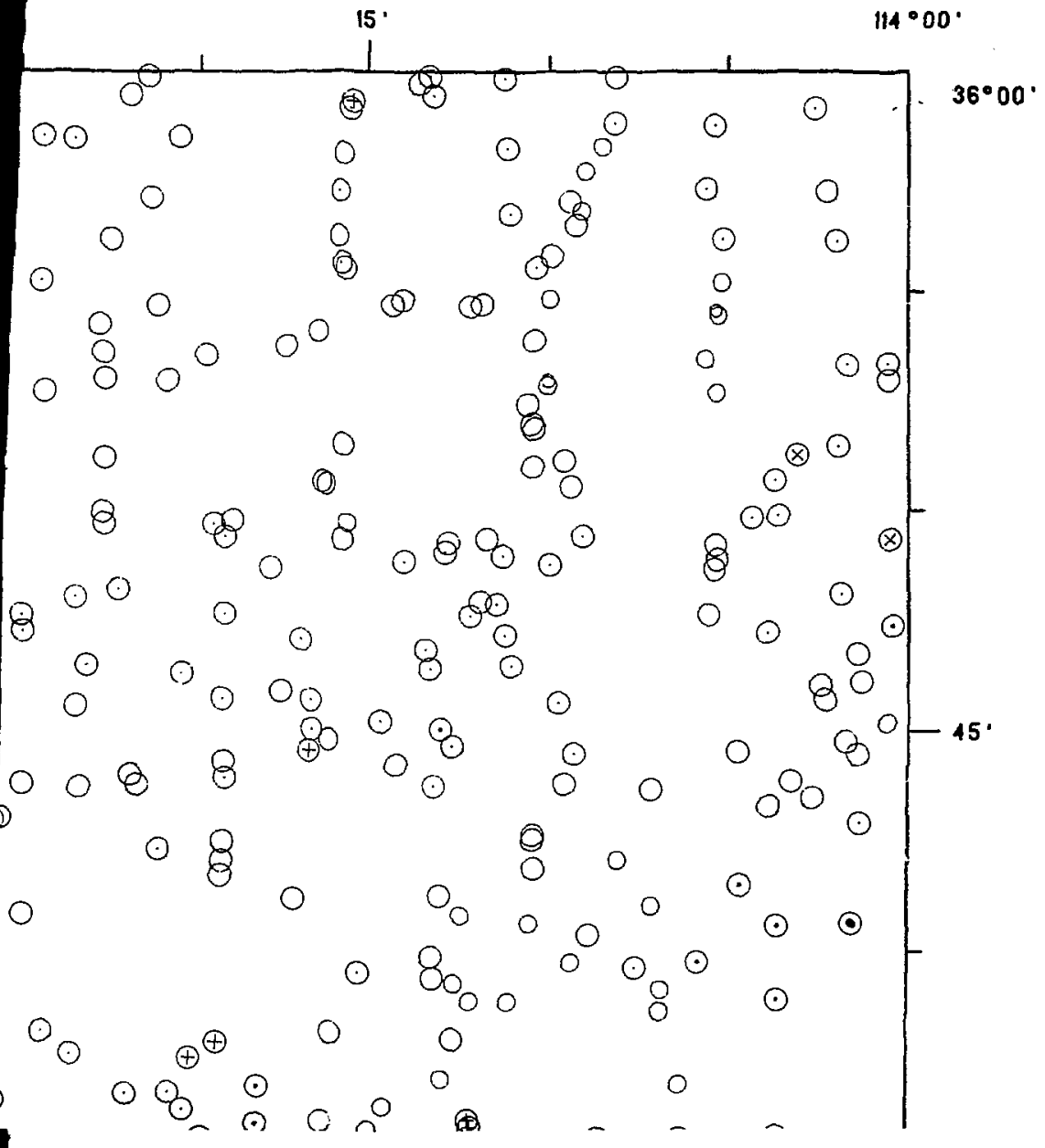




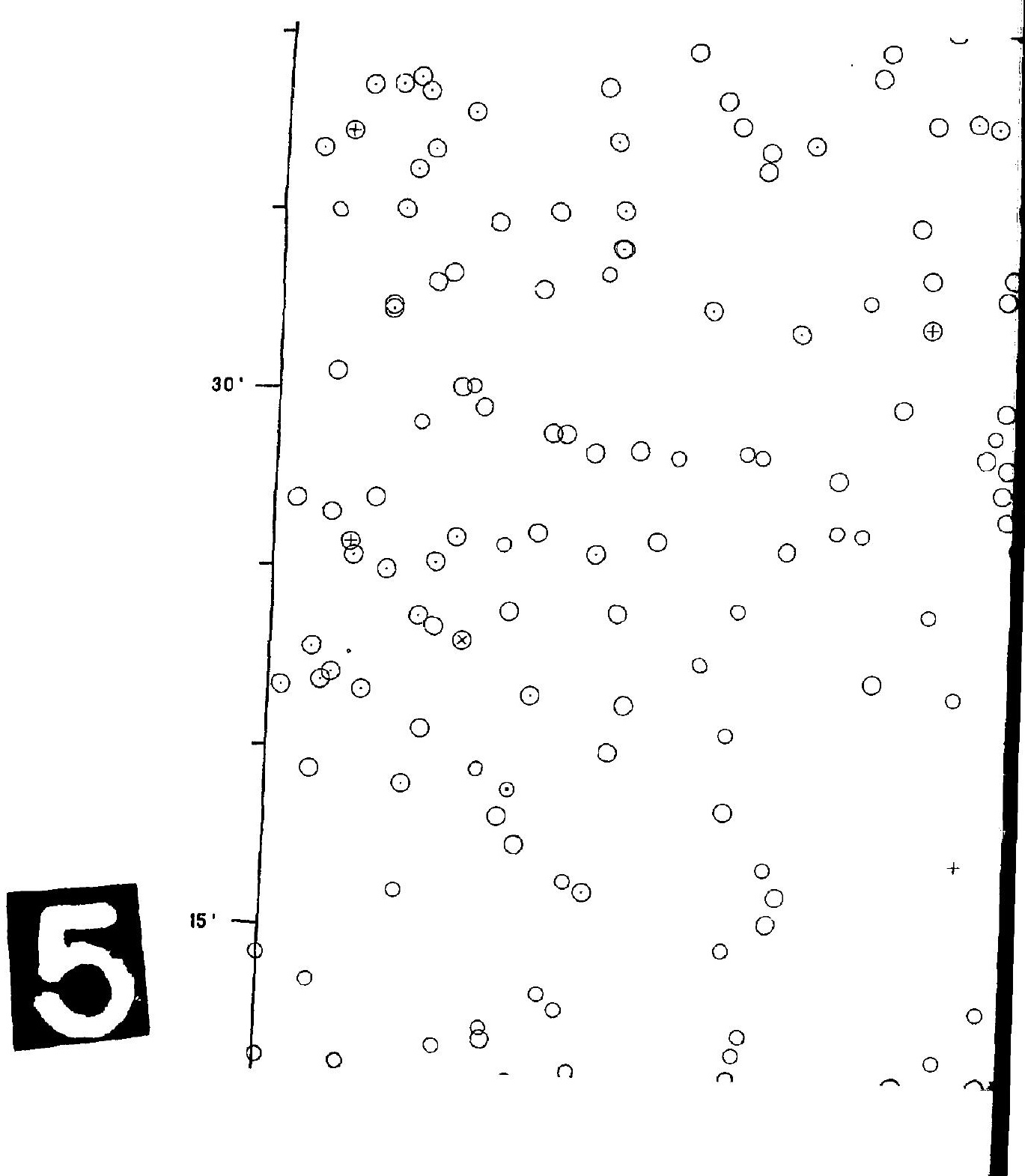




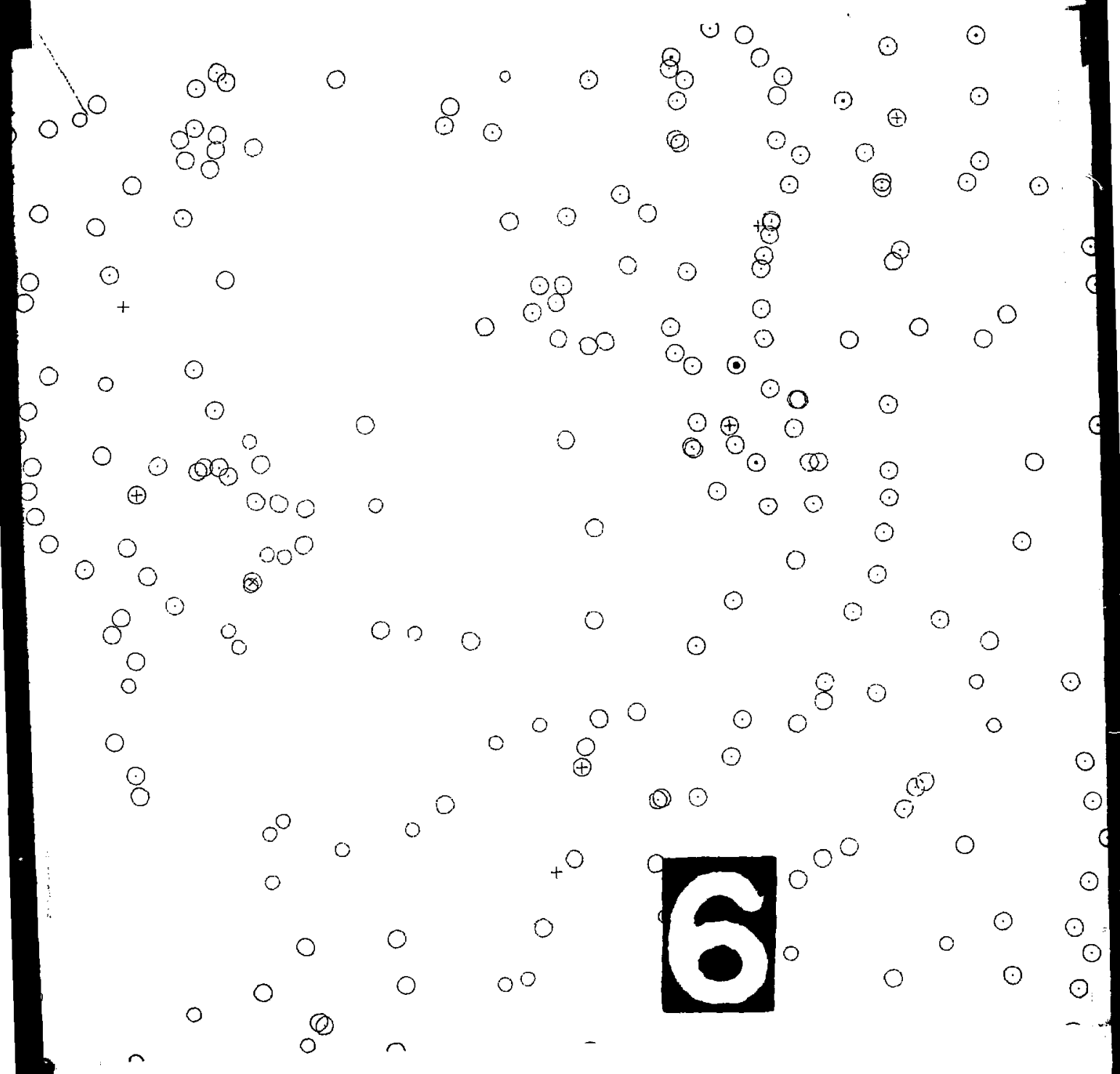




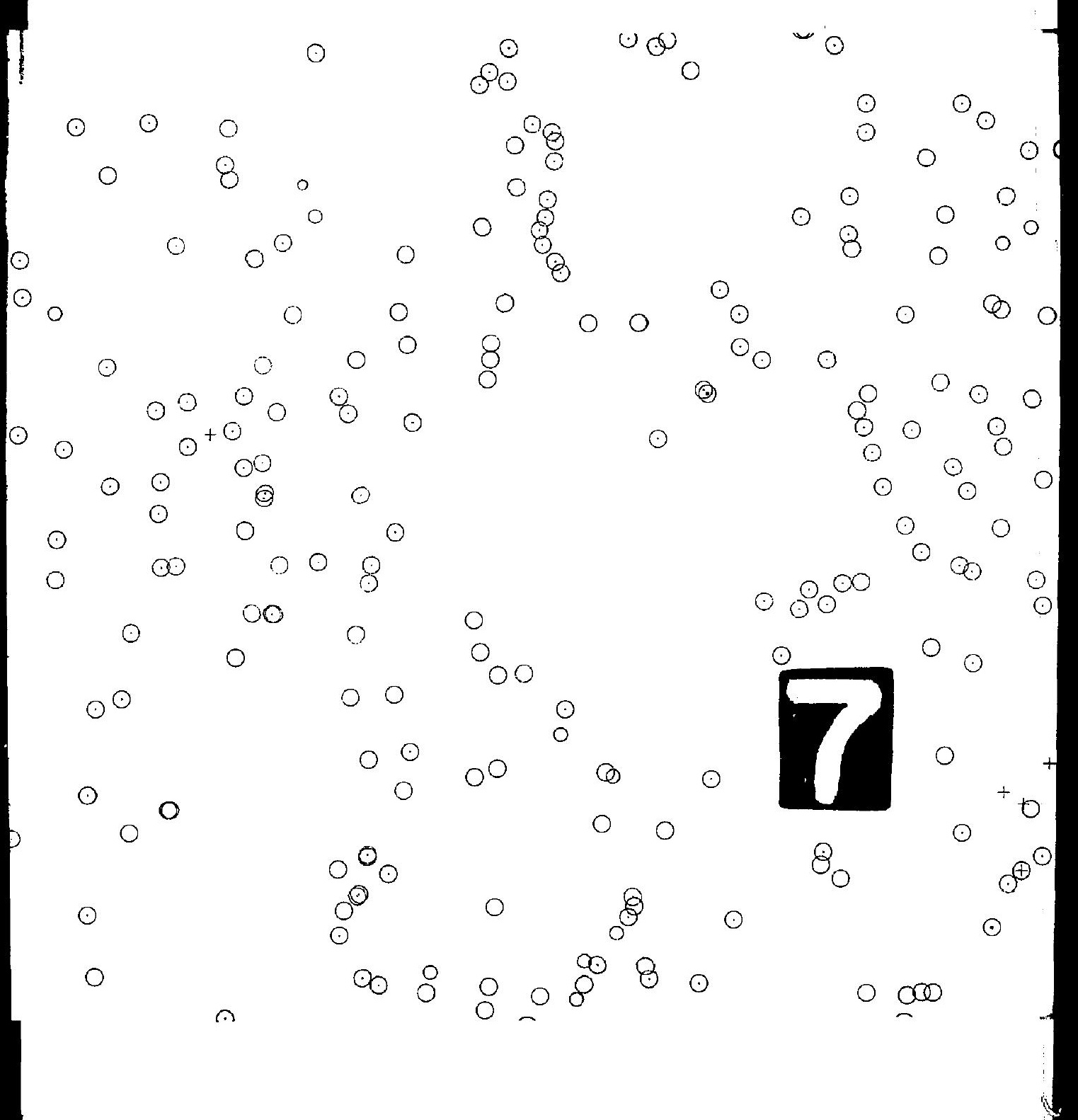



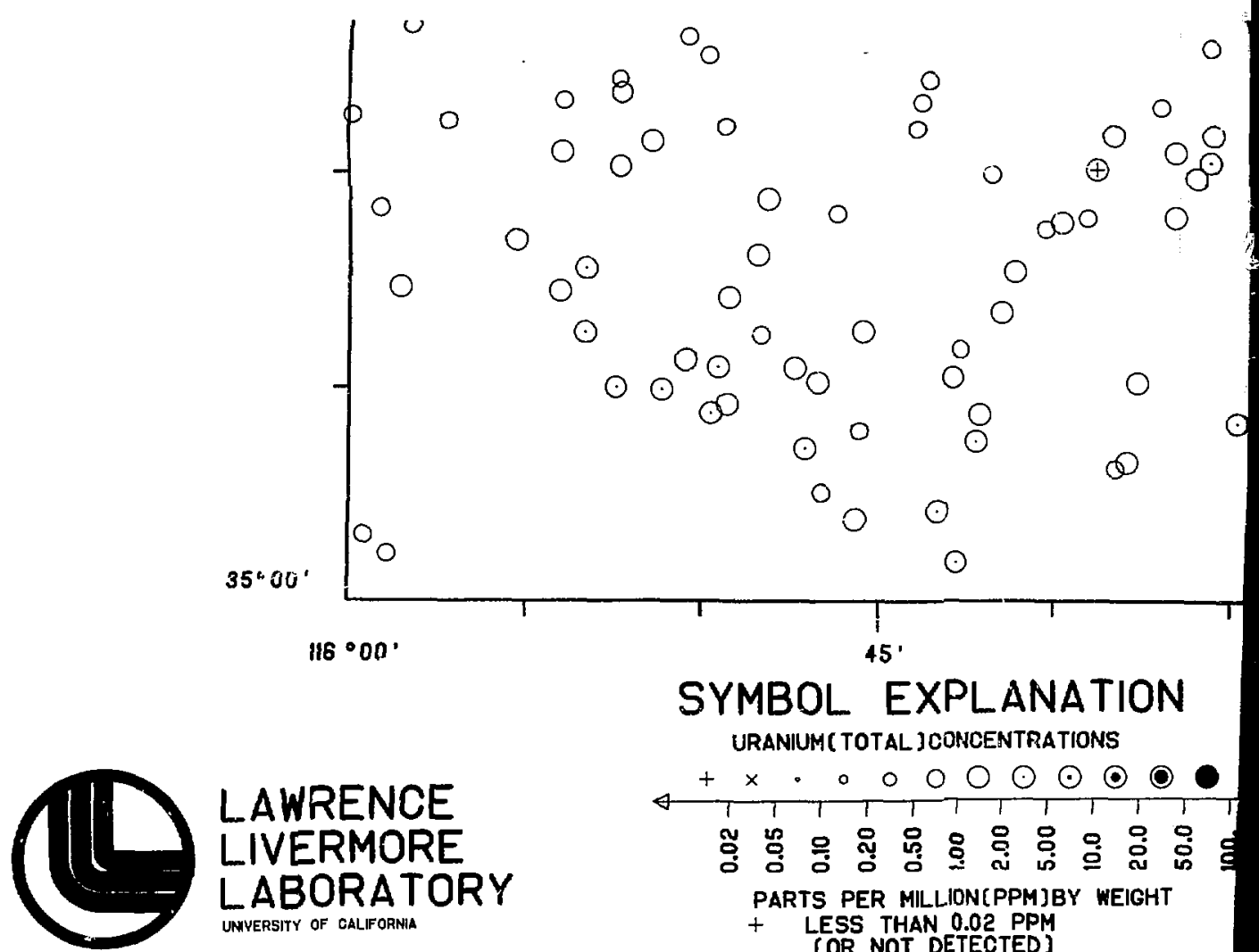

\section{SYMBOL EXPLANATION}

URANIUM( TOTAL JCONCENTRATIONS

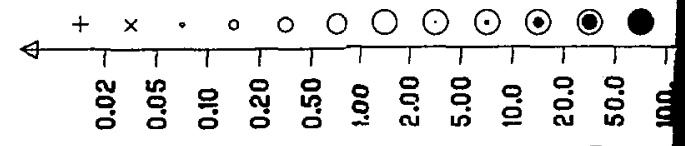

PARTS PER MILLION(PPM)BY WEIGHT

$+\quad$ LESS THAN 0.02 PPM

(OR NOT DETECTED)

$\star$ greater than 500 PPM

SER NO. LLI_: NURE :HSSR $14,28,35$ R $07 / 29 / 78$

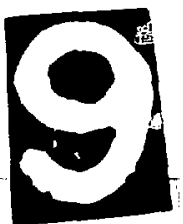




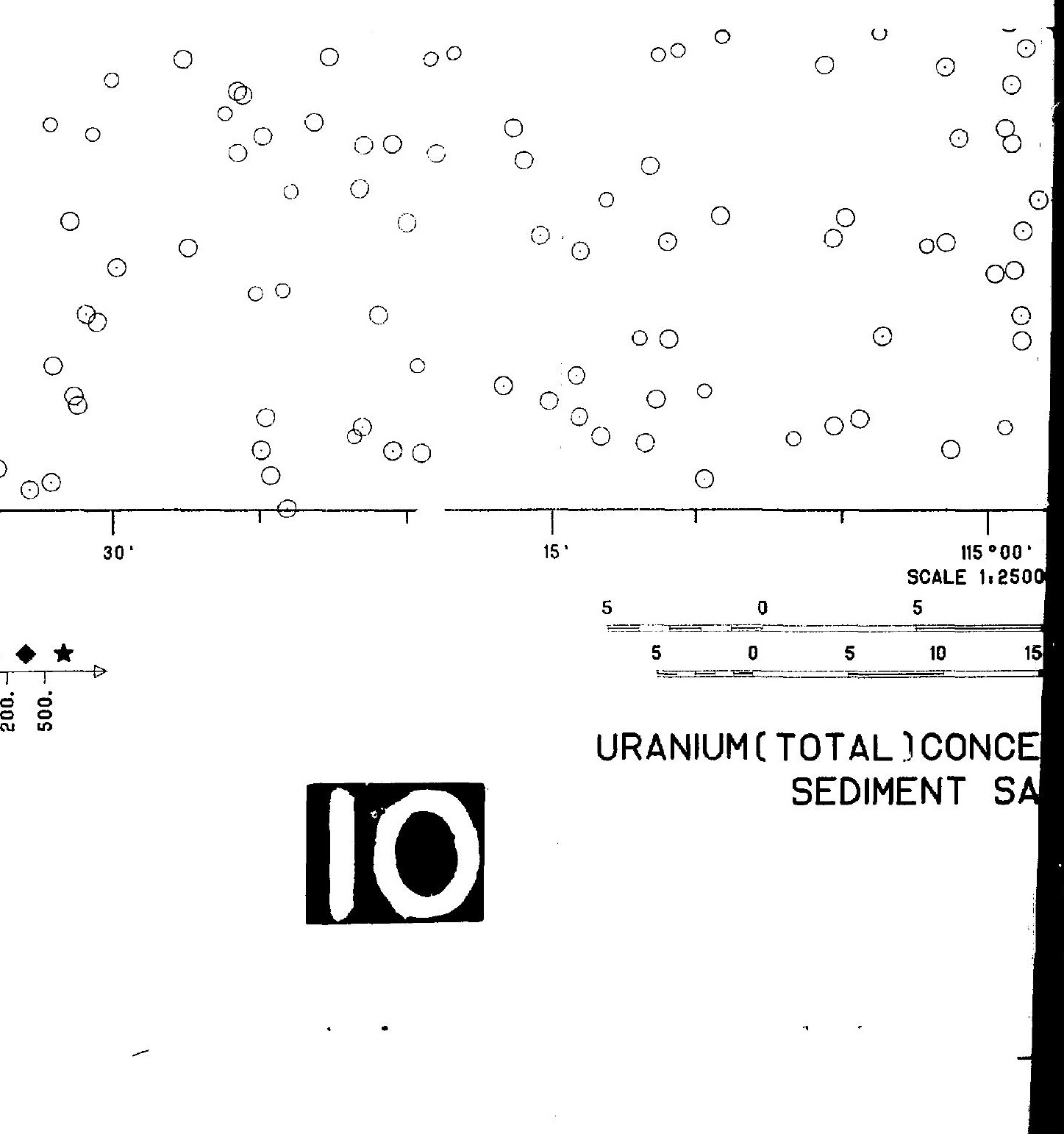


O

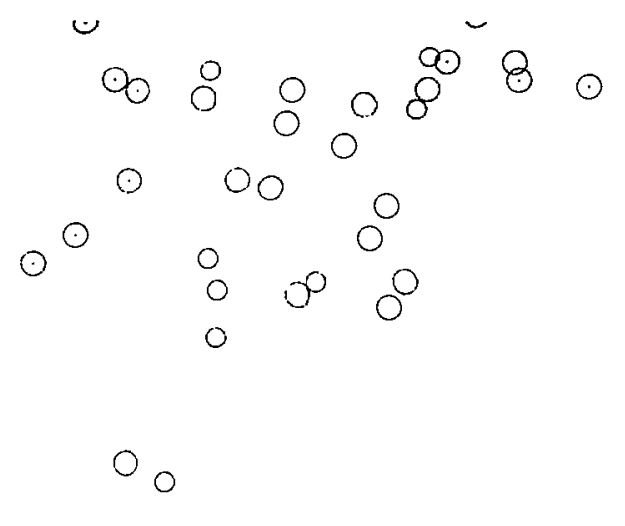

$8^{\circ}$

0

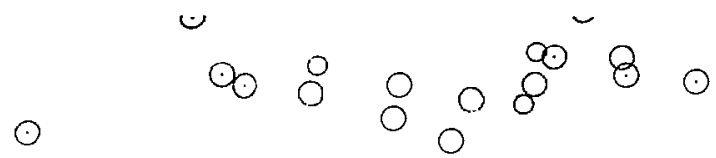

$\odot^{\circ} 0$

0

○

- 00

$\odot \odot$

$\bigcirc$

C

$\odot$

(2) $\odot$

$\odot \odot$

$\odot \odot \odot$

$\odot_{\odot} \odot \odot \odot$

00

O

0

50000

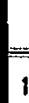

10

15

20

25

20 STATUTE MILES

30 KILOMETERS

4

ENTRATIONS (PPM)

AMPLES

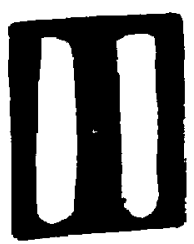




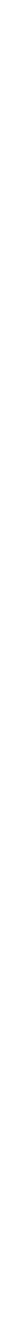




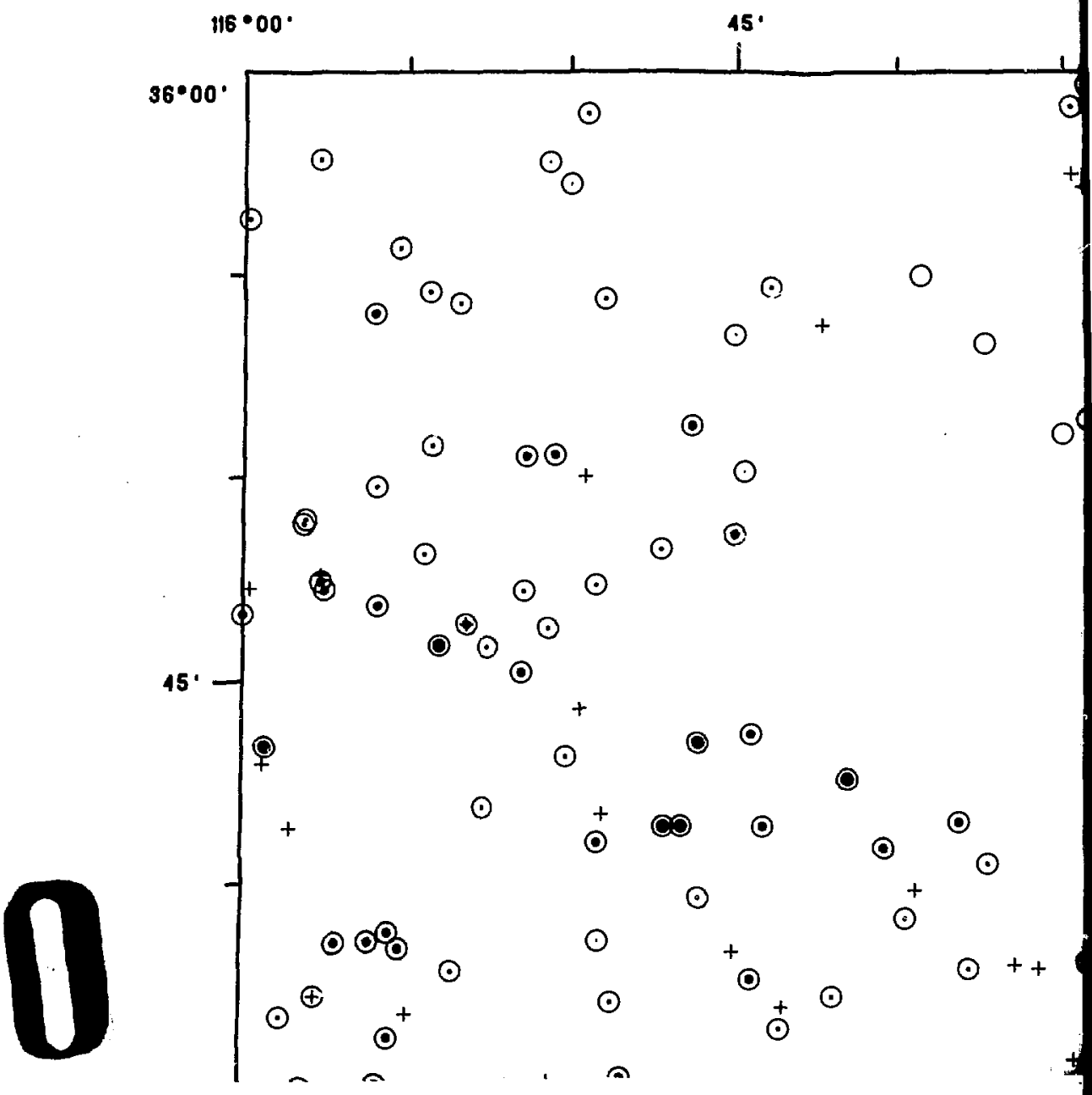


KINGMA

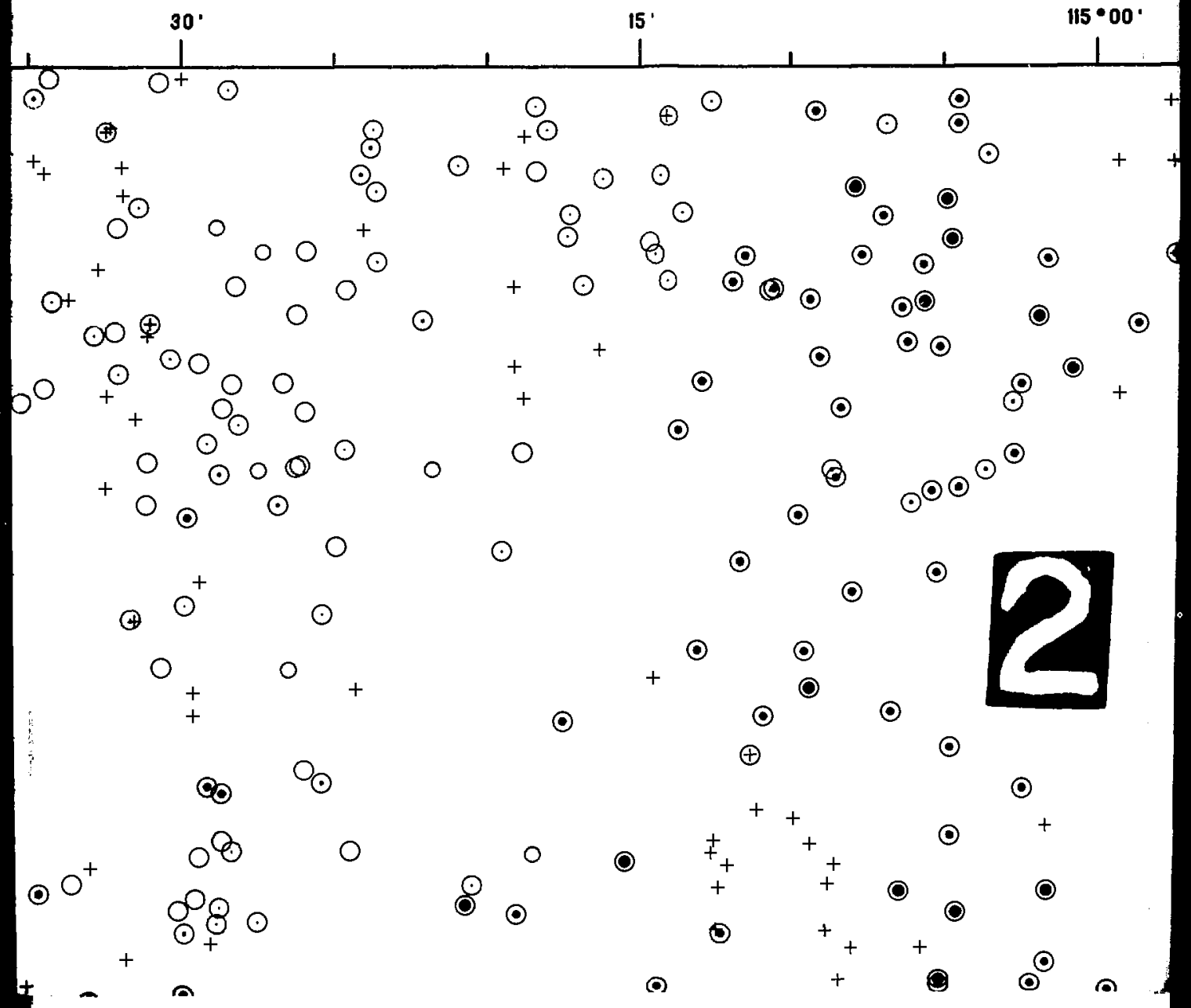


NI $11-03$

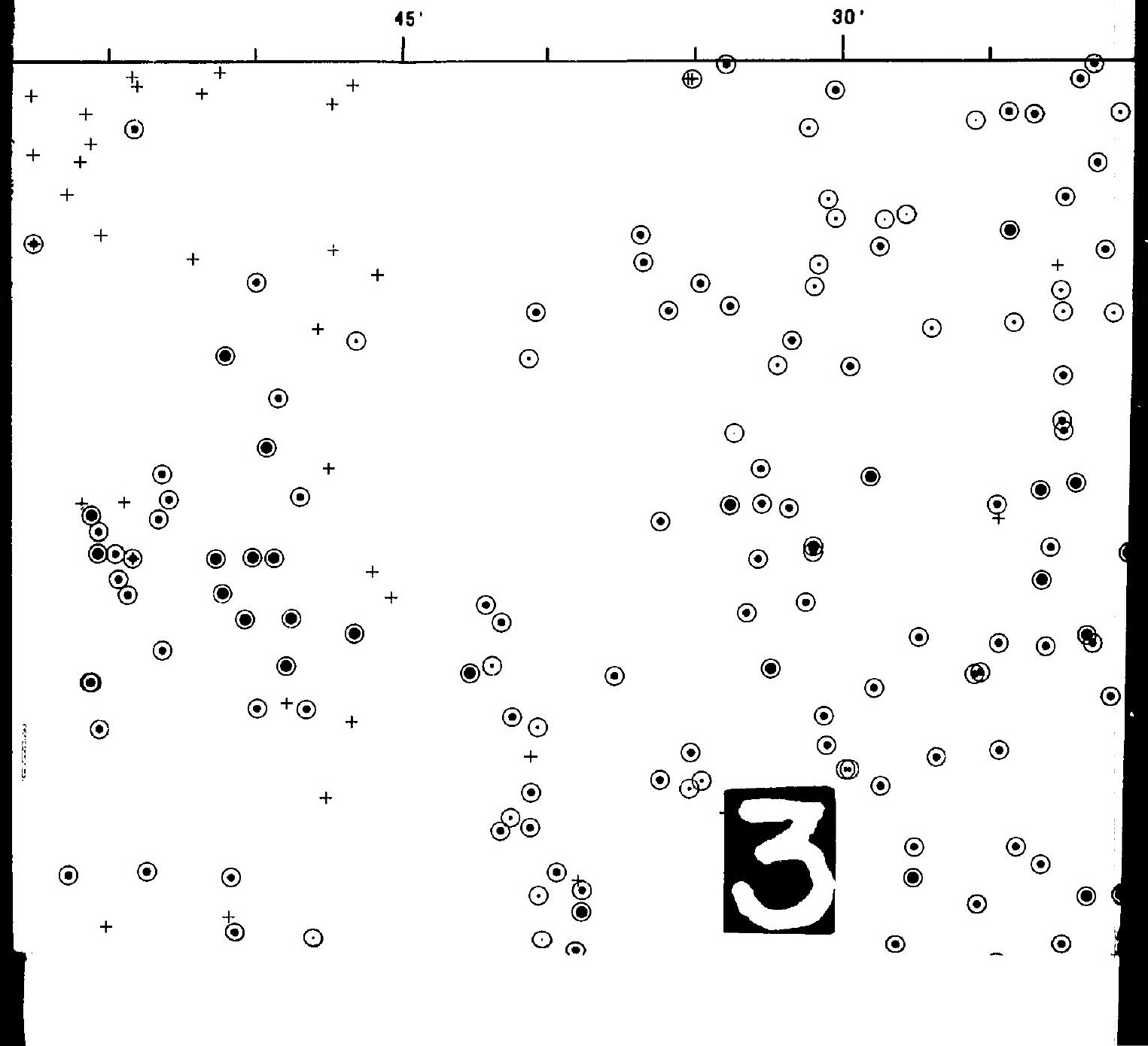


D3

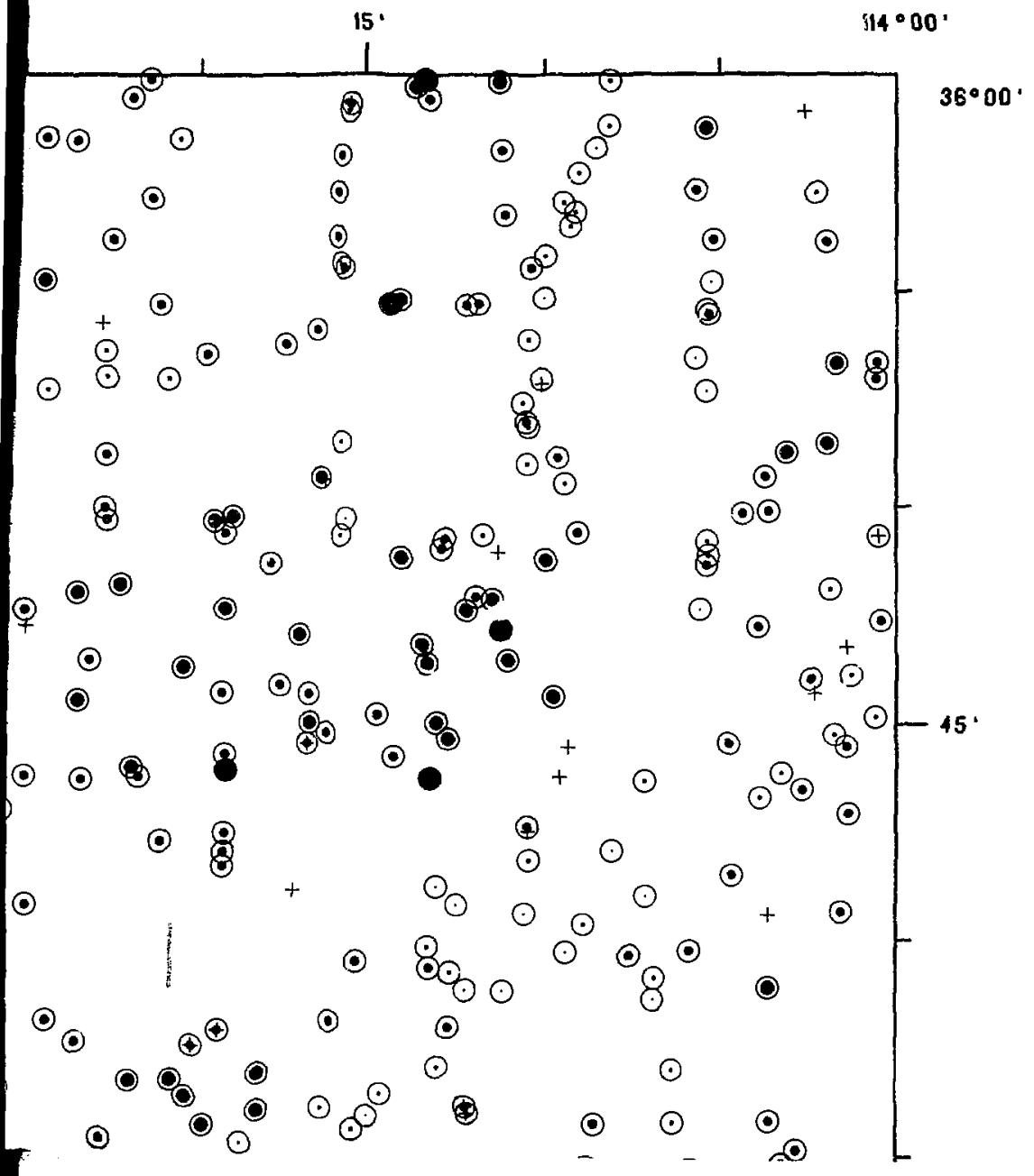


$\odot$

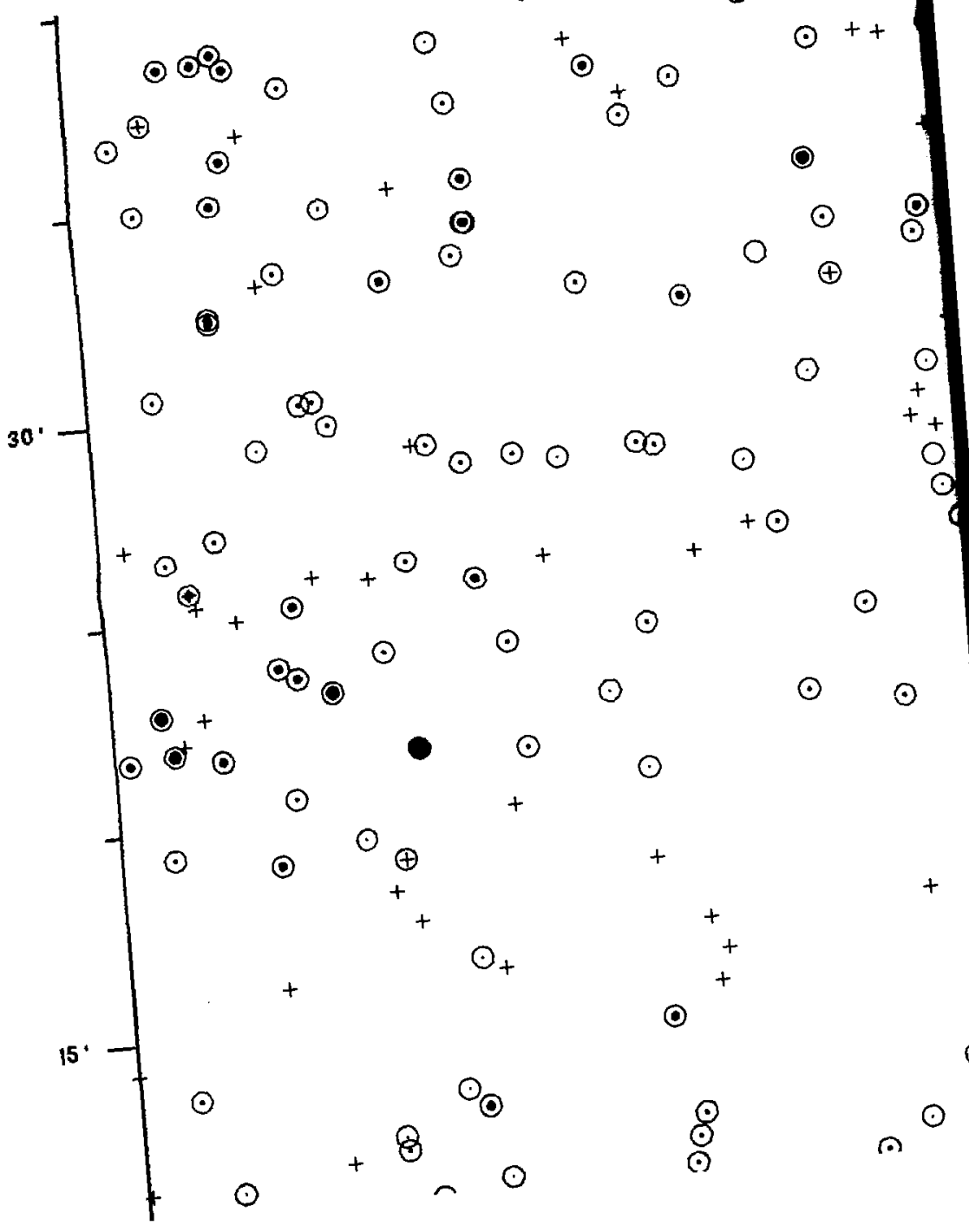


$+\odot_{\odot}^{\odot} \quad-{ }_{+}^{+}=$

-

$+$

○

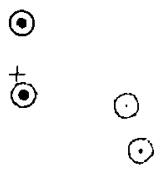

$\odot^{+}$

$\odot$

$(\bullet$

$\odot$

$\odot \odot$

○

$\odot$

$0^{+} \odot$

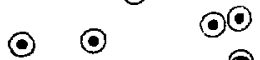

$\circ$

○

○

$\infty$

0

$\odot$

○

0

$\circ$

○

$\odot$

8

O)

$\odot$

$\odot$

$\odot$

-

$\odot$

8

$\odot$

- $\odot$

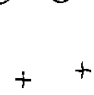

$\odot$

(.)

$+$

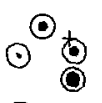

$\odot$

$\odot$

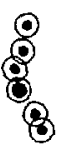

$\odot$

8

$\odot$

○ $\odot$

$\odot$

$\odot$

$\odot$

$\odot$

○

$\odot$

a
둥

$\odot$

${ }_{\odot}$

$\odot$

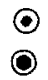

$\circ$

$\odot$

○

8

$\odot$
$+\quad \odot$

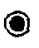

$\odot$

$0^{\circ} 0^{\infty}$

○

(อ)

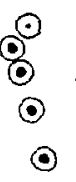

(

- 0

$\odot$

-

$\odot$

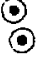

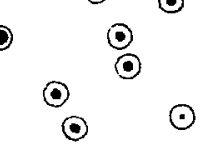

$\odot$

$\odot$

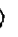

$(-$

$\odot$

(

○
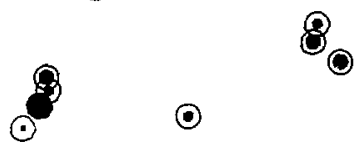

$\odot$

$\odot$

$\odot$

○

$+$

O

$\theta^{\ominus}$

○

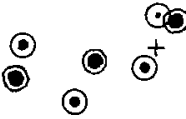

o

○

○ 


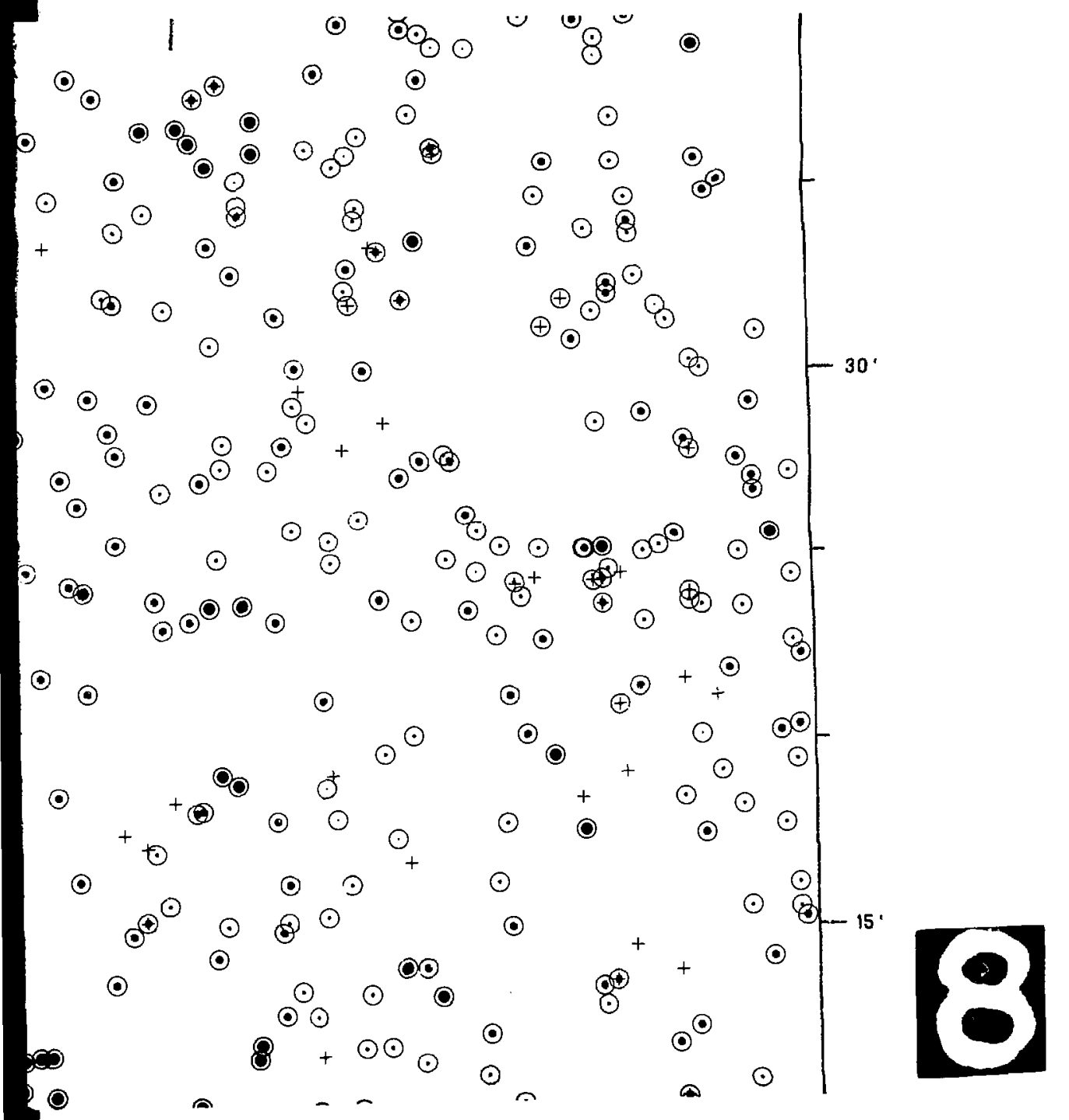




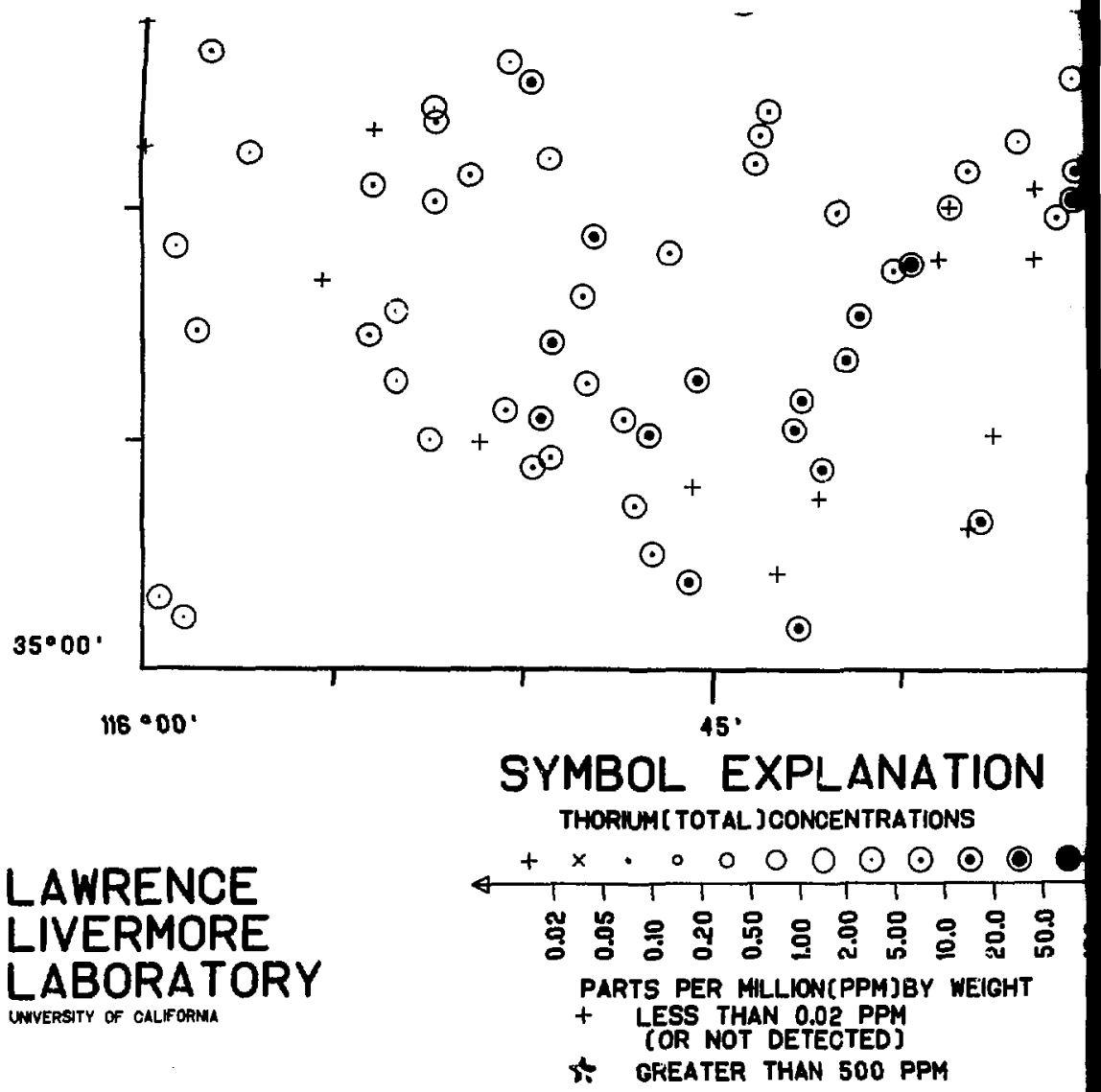

SER NO. LLL, NURE,HSSR $17,27,35$ R 07/29/78

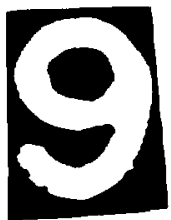


$\Theta$

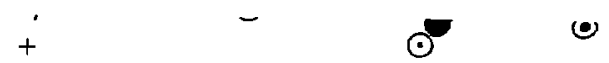

○

$\odot$

O<smiles>[O-][O-]</smiles>

80

$\odot$

$+00$

$\odot$

○ $\odot$

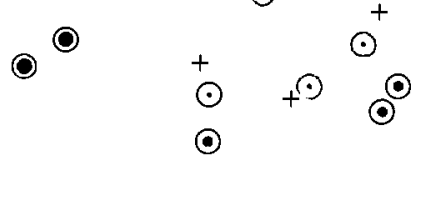

$\odot \odot$

$b^{\odot} \odot$

( )

$\odot$

$\odot$

$\odot$

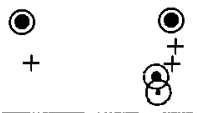

08

- CO

$\bigcirc$

6

$\stackrel{0}{\circ}$

○

6

$(9$

$\odot \bigcirc$

() 0

$\odot_{\odot} \odot \odot \odot$

4

ENTRATIONS (PPM)

AMPLES

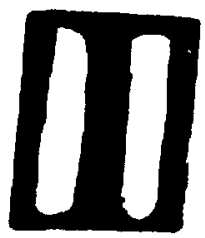


0
$\odot \odot \odot$
$8+\odot \odot \odot$
$\odot$
$8^{\top}$
$\odot$
$\circ$

○

- $0^{+}$
- $\odot \odot \&$
O

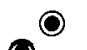

$(9)$

8

$0_{0}$

$\odot \odot$

- 0

O

( $\odot$

$\odot \odot \odot \odot$

○

$\infty$
$\circ+8$
800

妇

${ }^{\infty} \infty$

O

OO

$0_{0}^{\circ} 8$

$\odot \odot$

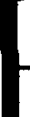

o

$\infty$

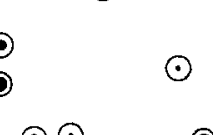

$00^{+}$

$0^{\odot} \Theta$

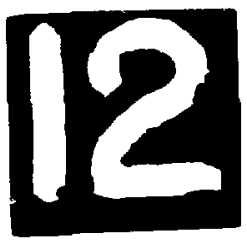

$35^{\circ} 00^{\prime}$

$15^{\circ}$

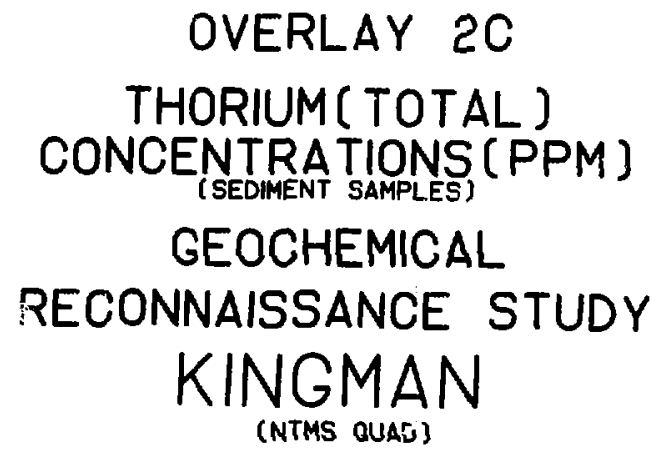

